Portland State University

PDXScholar

$1-1-2010$

\title{
Women and Resistance in the African Diaspora, with Special Focus on the Caribbean (Trinidad and Tobago) and U.S.A.
}

Clare Johnson Washington

Portland State University

Follow this and additional works at: https://pdxscholar.library.pdx.edu/open_access_etds Let us know how access to this document benefits you.

\section{Recommended Citation}

Washington, Clare Johnson, "Women and Resistance in the African Diaspora, with Special Focus on the Caribbean (Trinidad and Tobago) and U.S.A." (2010). Dissertations and Theses. Paper 137.

https://doi.org/10.15760/etd.137

This Thesis is brought to you for free and open access. It has been accepted for inclusion in Dissertations and Theses by an authorized administrator of PDXScholar. Please contact us if we can make this document more accessible: pdxscholar@pdx.edu. 
Women and Resistance in the African Diaspora, with Special Focus on the Caribbean (Trinidad and Tobago) and U.S.A.

$$
\text { by }
$$

Clare Johnson Washington

A thesis submitted in partial fulfillment of the requirements for the degree of

\author{
Master of Science \\ in \\ Interdisciplinary Studies
}

Thesis Committee:

E. Kofi Agorsah, Chair

Primus St. John

Rita Pemberton

Portland State University

(C)2010 


\begin{abstract}
American history has celebrated the involvement of black women in the “underground railroad,” but little is said about women's everyday resistance to the institutional constraints and abuses of slavery. Many Americans have probably heard of and know about Harriet Tubman and Sojourner Truth - two very prominent black female resistance leaders and abolitionists-- but this thesis addresses the lives of some of the less-celebrated and lesser-known (more obscure) women; part of the focus is on the common tasks, relationships, burdens, and leadership roles of these very brave enslaved women.
\end{abstract}

Resistance history in the Caribbean and Americas in its various forms has always emphasized the role of men as leaders and heroes. Studies in the last two decades Momsen 1996, Mintz 1996, Bush 1990, Beckles and Shepherd, Ellis 1985, 1996, Hart 1980, 1985) however, are beginning to suggest the enormous contributions of women to the successes of many of the resistance events. Also, research revelations are being made correcting the negative impressions and images of enslaved women as depicted in colonial writings (Mathis 2001, Beckles and Shepherd 1996, Cooper 1994, Campbell 1986, Price 1996, Campbell 1987). Some of these new findings portray women as not only actively at the forefront of colonial military and political resistance operations but performed those activities in addition to their roles as the bearers of their individual original cultures. Their goal was achievement of freedom for their people. 
Freedom can be seen as a magic word that politicians, propagandists, psychologists and priests throw around with ease. Yet, to others freedom has a different meaning which varies with the individual's sense of associated values. Freedom without qualification is an abstract noun meaning, "not restricted, unimpeded", or simply, "liberty"; but when it is concretized in individual situations its meaning is narrowed, and it becomes clear that no one can be fully free. Yet the love of freedom is one of our deepest feelings, a truly heartfelt cry, freedom of wide open spaces, liberty to enjoy the taste, in unrestricted fashion, of the joys of nature, to live a life free from external anxieties and internal fears; freedom to be truly ourselves. All living creatures, even animals seem to value their freedom above all else.

Enslaved people were not submissive towards their oppressors; attempts were made both subtly, overtly and violently to resist their so-called "masters" and slavery conditions. Violent and non-violent resistance were carried out by the enslaved throughout colonial history on both sides of the Atlantic, and modern historical literature shows that women oftentimes displayed more resistance than men. ${ }^{1}$ Enslaved Africans started to fight the transatlantic slave trade as soon as it began. Their struggles were multifaceted and covered four continents over four centuries. Still, they have often been underestimated, overlooked, or forgotten. African resistance was reported in European sources only when it concerned attacks on slave ships and company barracoons, but acts of resistance also took place far from the coast and thus escaped the slavers' attention. To discover them, oral history, archaeology, and autobiographies and biographies of African

\footnotetext{
${ }^{1}$ De Vertueil, Anthony. To Find Freedom: Historical Sketches of Trinidad. Port of Spain, Trinidad: The Litho Press,
} 1998. 
victims of the slave trade have to be probed. Taken together, these various sources offer a detailed image of the varied strategies Africans used to defend themselves and mount attacks against the slave trade in various ways. ${ }^{2}$

The Africans' resistance continued in the Americas, by running away, establishing Maroon communities, sabotage, conspiracy, and open uprising against those who held them in captivity. Freed people petitioned the authorities, led information campaigns, and worked actively to abolish the slave trade and slavery.

In Europe, black abolitionists launched or participated in civic movements to end the deportation and enslavement of Africans. They too delivered speeches, provided information, wrote newspaper articles and books. Using violent as well as nonviolent means, Africans in Africa, the Americas, and Europe were constantly involved in the fight against the slave trade and slavery.

Women are half the human race and they're half of history, as well. ${ }^{3}$ Until recent years, Black women's history has been even less than that. Much work has been done studying the lives of slaves in the United States and the slave system. From elementary school in the USA on through college we are taught the evils of slavery that took place right here in the Land of the Free. However, how much do we know about the enslaved in other places, namely the Caribbean? The Caribbean was the doorway to slavery here in the New World, and so it is important that we study the hardships that enslaved people suffered in that area. Slaves regularly resisted their masters in any way they could.

\footnotetext{
${ }^{2}$ Diouf, Sylviane A., African Resistance, The Abolition of The Slave Trade, Schomburg Center for Research in Black Culture, 2007, http://abolition.nypl.org/print/african_resistance/

${ }^{3}$ Lewis, Jone Johnson, Black History and Women, About.com Guide, "About Women's History", http://womenshistory.about.com/od/afraamermore/tp/black_history.htm, June 7, 2010.
} 
Female slaves, in particular, are reported to have had a very strong sense of independence and they regularly resisted slavery using both violent and non-violent means. The focus of my research is on the lives of enslaved women in the Caribbean and their brave resistance to bondage. Caribbean enslaved women exhibited their strong character, independence and exceptional self worth through their opposition to the tasks they performed in the fields on plantations. Resistance was expressed in many different rebellious ways including not getting married, refusing to reproduce, and through various other forms as part of their open physical resistance.

The purpose of this project is to identify the role enslaved women in both the Caribbean and the USA played in some of the major uprisings, revolts, and rebellions during their enslavement period. The research identifies individual female personalities, who played key roles in not only the everyday work on plantations, but also in planning resistance movements in the slave communities. This study utilizes plantations records, archival material, and official sources. Archival records from plantations located in archives and county clerks' offices; interviews with sources such as researchers and experts familiar with the plantations of slave communities in designated areas; and research in libraries, as well as other sources, oral histories, written and oral folklore, and personal interviews were used as well. 


\section{DEDICATION}

To my Mom, who embodies the perfect reconciliation between beauty and intelligence, and to my Dad, who probably would never have understood my research undertaking but would have supported me and watched me become a better feminist nonetheless. To my sisters and brother, who always share their happiness and laughter openly and abundantly, and believe in the magic that they say only I can work!

To Clarence, Ann, Derrick, and Ciera - the bright lights in my life. 


\section{ACKNOWLEDGEMENTS}

Part of this study was funded by a J. William Fulbright Fellowship grant. The Department of Black Studies kept me financially solvent with summer teaching assistantships throughout my graduate work. This research would not have been possible without the guidance and support from my advisor Professor E. Kofi Agorsah. Applications for grants, office visits, editing, and great discussions are some of the many contributions that he has made. During my studies there were times when work commitments and intermittent financial stress made me believe that I would not be able to see this journey through. It was during these times, and many others, that Professor Agorsah's words of encouragement and his confidence in my ability gave me the motivation to persist. I attribute the level of my Masters degree to his encouragement and effort and without him this thesis would not have been completed or written. His dedication to education is unsurpassed. I would be remiss if I didn't thank and acknowledge Toeutu Faaleava, Director of the Ronald E. McNair Scholars Program at PSU, Jolina Kwong, Associate Director of the Ronald E. McNair Program at PSU and Tyanne Conner, my dear friend and member of my cohort from the McNair Scholars Program.

I offer my sincerest gratitude to Professor Primus St. John who has supported me with his patience and poetic knowledge, while allowing me the room to work in my own way, as I find and nurture my own poetic voice in the writing of this thesis. No words of thanks can adequately express the depth of my appreciation to Professor Maria DePriest for all the times she reminded me to be true to who I really am. One simply could not 
wish for a better friend and advisor. Special thanks to Dr. Rita Pemberton of the History Department of the University of the West Indies, St. Augustine Campus in Trinidad and Tobago, for her unselfish guidance and support during and after my Fulbright grant period at the campus. Not only was she an inspirational mentor, but was also nothing short of a big sister to me. Thanks also to Dean Ian Robertson of the Faculty of Humanities and Education for his invitation that allowed for my research to commence at the University of West Indies (UWI), St. Augustine Campus; his secretary, Mrs. Kathleen Reid for her professional assistance in writing the necessary correspondence that enabled me to gain access to the library; and Ms. Lorraine Nero and her staff of the West Indiana Special Collections Department of the Main Library.

I also acknowledge and thank Professor Rhoda Reddock of the Centre for Gender and Development Studies at UWI for taking the time away from her busy schedule to grant me an interview and share her thoughts on the women's movement in the Caribbean, particularly in Trinidad and Tobago. In addition, I thank the following individuals who also granted me interviews and are in support of my project, including: Father Anthony de Verteuil of the Spiritan House at St. Mary's College in Port of Spain, Trinidad; Professor Bridget Brereton of the History Department at UWI; and Mrs. Hazel Brown, a founding member of the Network of NGO's of Trinidad and Tobago for the Advancement of Women; Mr. Kafra Kambon, who made the time I spent interviewing him about the women of the Black Power Movement in Trinidad \& Tobago, an absolute delight. He was unreserved in sharing with me about the lives of those women during that era. I cannot forget the help and sincere assistance I received from Ms. Avril Belfon, 
Senior Archives and Records Officer and her staff, especially Mr. Rawle Chase and Ms. Marcella Thompson at the National Archives of Trinidad and Tobago; and Maureen Daniel-Braveboy, attorney at law in Port of Spain, who was an invaluable comrade during my stay in Trinidad. Maria Peter and Shinelle Martin of the History Department at the University of the West Indies (UWI), for their willingness to always help with my printing and copying needs; Marsha Wassel of Harpers Ferry NHP, for her assistance in providing images from the Harpers Ferry NHP Historic Photo Collection. I also thank with deepest appreciation, Antoinette Harrell of the Gathering of Hearts Organization, for being a real woman of spirit, resistance, and strength. Thanks to Courtney Hanson for constantly reminding me that I could do whatever I set my mind to, and then handing me two Ghirardelli chocolate squares to make things all better. My loving son, Clarence who has always given his moral support. Angela Canton who is never more than a telephone call away; and I’m very grateful to Karen Popp for saying “yes” to the call for help on my committee. 


\section{TABLE OF CONTENTS}

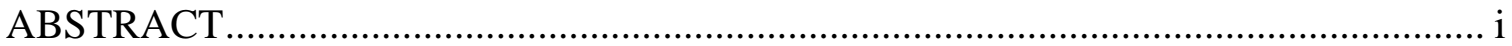

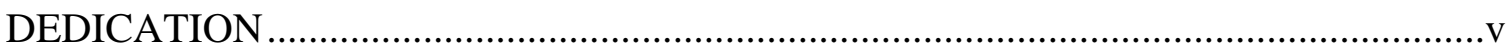

ACKNOWLEDGEMENTS

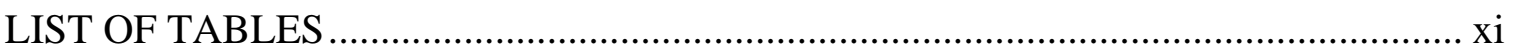

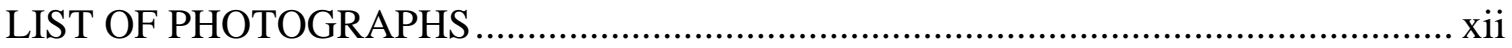

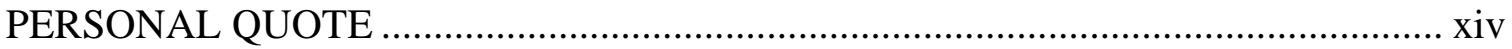

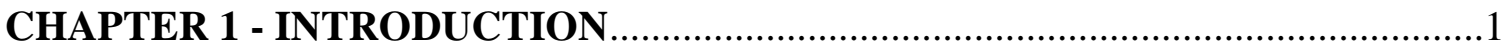

The Enslaved Woman's Role in Slavery ..........................................1

Slavery and Trade in the Caribbean ..............................................9

Aspects of Women's Resistance ...................................................10

Women at the Beginning ...........................................................11

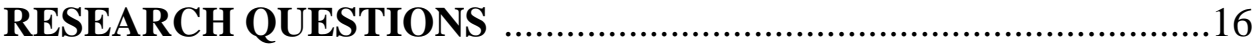

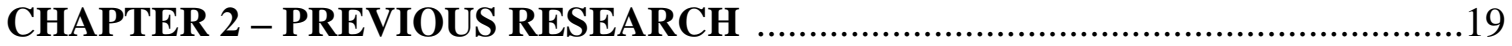

CHAPTER 3 - WOMEN OF RESISTANCE, SPIRIT AND STRENGTH .............25

The Caribbean:

Queen Anacona - “The Golden Flower” (Taino Queen)..............25

Nanny of the Maroons - (Maroon Wars; 1720-1739) ...................26

Marie Jeanne, Claire Heureuse, Ezili Dantó ..............................33

(Women of the Haitian Revolution - 1802-1804)

Nanny Grigg - 1816 Barbados Uprising .....................................35

Queen Coziah Harmon - 1872 Coal-Carriers Strike......................38

The Living African-American History ........................................39

Ti Piggi/Piggy - 1876 Belmanna Riots (Tobago) ........................40

Queen Mary Thomas - 1878 Fireburn Labor Revolt .....................44

Elma Francois - Founder, NWCSA ...........................................48

(1937 Butler Riots)

Gene Miles - 1965 Gas Station Racket (Trinidad \& Tobago) .......50

(Father Anthony de Verteuil Interview)

Gene Miles Case Notes..............................................................51

Jacqueline Creft - 1979 Grenada Revolution.................................61

Rhoda Reddock - CAFRA (Trinidad and Tobago).......................64

Hazel Brown- Network of NGO's of Trinidad and Tobago for the

Advancement of Women .................................................66

Caribbean Folklore - Legend of Gang Gang Sarah......................68

\section{The U.S.A:}

Jenny Slew

Elizabeth Freeman (also known as "Mum Bett”) ..........................71

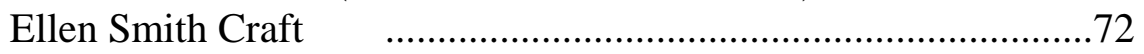

Carlotta Walls LaNier ..............................................................76 
Before Rosa Parks ..............................................................78

Claudette Colvin ..............................................................78

Women of the Montgomery Bus Boycott............................83

Rosa Parks ................................................................86

Lillian Davis Roberts - DC37 Labor Union (NY, NY) ..................88

Mae Wall - One of the Last Slaves in Mississippi..........................93

Antoinette Harrell-Miller .....................................................................97

American Folklore - Voodoo Queens ........................................100

Marie LaVeau ...................................................................101

Mary Ellen "Mammy" Pleasant ..........................................105

Sanite Dede ...................................................................115

CHAPTER 4 - WOMEN OF THE BLACK POWER MOVEMENT .......................117

The Caribbean:

Trinidad and Tobago

Interview - Dr. Rita Pemberton...........................................122

Interview - Professor Rhoda Reddock ..............................122

Interview - Khafra Kambon .............................................123

CHAPTER 5 - WOMEN OF AFRICAN TOWN, ALABAMA …………………....125

Cudjo and Abache

CHAPTER 6 - OTHER LESSER-KNOWN WOMEN ...............................................127

Remember the Ordinary Heroes....................................................127

“Stagecoach Mary Fields” - USA 127

Minnie M. Geddings Cox - USA ....................................................130

Godmother of the Civil Rights Movement......................................132

Dorothy Height - USA

Aba Rebellion of 1929 (or The War of the Women) 133

Madam Mary Okezie -- Nigeria..................................................133

Other Major Figures in the Women's War ...................................136

The Butterflies (Mirabal Sisters) .................................................137

Dede Mirabel - Dominican Republic ..........................................138

CONCLUSION

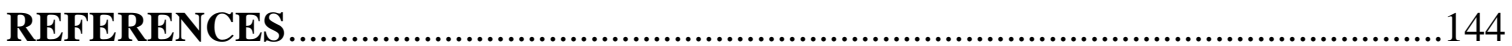

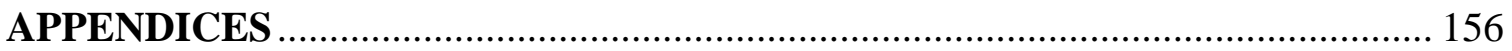

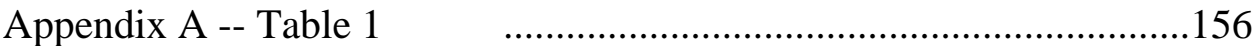

Appendix B - Table $2 \quad$ ……………………………………......158

Appendix C -- Table $3 \quad$ …………………………………….......159

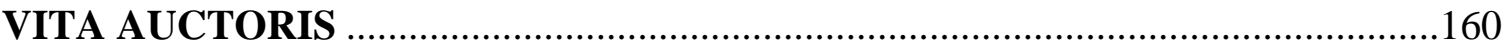




\section{LIST OF TABLES}

$\begin{array}{ll}\text { Number } & \text { Page }\end{array}$

Table 1: Timeline of Rebellions, and Resistance Movements (Caribbean) 156

Table 2: Some Obscure Women of the African Diaspora 158

Table 3: Timeline of Rebellions, and Resistance Movements (U.S.A.) 159 


\section{LIST OF PHOTGRAPHS}

$\begin{array}{lll}\text { Number } & \text { Page }\end{array}$

Photo 1: Queen Anacaona (Haiti) 25

Photo 2: Nanny of the Maroons (Jamaica) 26

Photo 3: Queen Nanny on 500 Dollar Bill 31

Photo 4: Suzanne "Sanite” Belair 33

Photo 5: Catherine Flon 34

Photo 6: Nanny Grigg and Bussa 35

Photo 7: Coal Carriers (1872 Coal Carrier's Strike - St. Thomas, USVI) 38

Photo 8: Women Coal Carriers 39

Photo 9: Women Coal Carriers Boarding Steam Ship 39

Photo 10: Government Proclamation (Belmanna Riots, Tobago, WI, 1876) 42

Photo 11: 1878 Fireburn Labor Revolt St. Croix (USVI) 47

Photo 12: Elma Francois (Founder, NWCSA) 48

Photo 13: Gene Miles (1965 Gas Station Racket Inquiry, Trinidad \& Tobago) 50

Photo 14: Father Anthony de Verteuil 52

Photo 15: Gene Miles in Zebra Outfit 53

Photo 16: Street in Lapeyrouse Cemetery 57

Photo 17: Lapeyrouse Cemetery 58

Photo 18: Gene Miles’ Family Plot (Lapeyrouse Cemetery) 58

Photo 19: Gene Miles’ Grave $\quad 59$

Photo 20: Gene Miles’Grave -\#2 59

Photo 21: Jacqueline Creft (1979 Grenada Revolution) 61

Photo 22: Rhoda Reddock 64

Photo 23: Hazel Brown 66

Photo 24: Hazel Brown at her office $\quad 67$

Photo 25: Silk Cotton Tree (Grave of Gang Gang Sarah) 68

Photo 26: Elizabeth "Mum Bett” Freeman 71

Photo 27: Ellen Smith Craft and William Craft $\quad 72$

Photo 28: Ellen Smith Craft Dressed a Man 74

Photo 29: CarlottaWalls Lanier (Little Rock Nine - 1957) 76

Photo 30: Claudette Colvin $\quad 78$

Photo 31: Claudette Colvin - \#2 79

Photo 32: Women of the Montgomery Bus Boycott - 1955

Photo 33: Rosa Parks on the Bus 86

Photo 34: Rosa Parks' arrest Photograph 87

Photo 35: Lillian Davis Roberts (Chicago Hospital Strike, 1950s) 88

Photo 36: Mae Wall and Cain Wall (Last Slaves of Mississippi, 1961-62) 93

Photo 37: Clare Washington, Mae Wall Miller, and Antoinette Harrell 95

Photo 38: Antoinette Harrell (Gathering of Hearts Organization, LA) 97

Photo 39: Voodoo Priestess Caricature in front of tomb 101 
Photo 40: Marie LaVeau 101

Photo 41: Marie LaVeau-2 103

Photo 42: Marie LaVeau Tomb Plaque 104

Photo 43: Marie LaVeau's Tomb 104

Photo 44: Mary Ellen “Mammy” Pleasant 106

Photo 45: Sanite Dede 115

Photo 46: Sanite Dede's Tomb 116

Photo 47: Liseli Daaga and Makandal Daaga 120

Photo 48: Kafra Kambon 123

Photo 49: Kafra Kambon - \#2 124

Photo 50: Abache (Clara Turner) and Cudjoe Kazoola Lewis 125

Photo 51: Mary Fields (aka "Stagecoach Mary”) 127

Photo 52: Mary Fields sitting in buggy 128

Photo 53: Minnie M. Geddings Cox 130

Photo 54: Dorothy Height 132

Photo 55: Dorothy Height at MLK’s “I Have a Dream” speech (1963) 132

Photo 56: Women of the Aba Rebellion, 1929133

Photo 57: The Mirabal Sisters 137

Photo 58: The Mirabal Sisters - \#2 137

Photo 59: Dede Mirabal 138 
"It is my Light, not my darkness, that most frightens me. I ask myself, who am I to be Brilliant, Gorgeous, Talented, and Fabulous?

Actually, who am I not to be?"

-Marianne Williamson ("A Return to Love") 


\section{CHAPTER 1 \\ INTRODUCTION}

\section{The Enslaved Woman's Role in Slavery}

Resistance to the institution of slavery was very widespread, persistent, and to be found in almost every aspect of slave life (Beckles, 1989: 152). All groups of slaves, regardless of sex, color, or work had anti-slavery mentality when it came to obeying their masters, and women were among leaders of some of these resistance movements. Women’s leadership roles, however, have often been ignored in writings about slave resistance. I first made this observation when I began writing my Fulbright grant proposal and wanted to find more information on Queen Coziah Harmon, leader of the Coal Carrier's Strike (or the Mexican Silver Revolt) on the island of St. Thomas, U.S. Virgin Islands. It was in reading Isaac Dookhan’s book, History of the Virgin Islands of the United States, that when relating the events about rebellions and revolts on the islands of St. Croix, St. John, and St. Thomas, Dookhan gives a lot of credit to David Hamilton Jackson, an educator and bookkeeper. Jackson later became the first labor union organizer in the Danish West Indies. Although Dookhan does mention Queen Mary Thomas and her role as leader of the Fireburn Labor Revolt in1878 on the island of St. Croix, USVI, he only mentions the two other female-led revolts in the Virgin Islands the St. John Slave Rebellion in1733 on the island of St. John,; and the Coal Carrier's Strike or Mexican Silver Riot of 1892, on the island of St. Thomas, but does not mention the names of the other two queens. The St. John Slave Rebellion was led by Queen 
Breffu; and the St. Thomas Coal Carrier's Strike was led by Queen Coziah Harmon, a Bamboula dancer.

Stephanie Camp notes in her book, Closer to Freedom: Enslaved Women and Everyday Resistance in the Plantation South (2007) that the culture of opposition created by enslaved women's acts of everyday resistance helped foment and sustain the more visible resistance of men in their individual acts of running away and in the collective action of slave revolts. ${ }^{1}$

Captive women were always active participants in resistance to slavery. For example, in one account, of a revolt during the middle passage, an English slaver captain, John Newton, reports that ships, which were under his command, survived at least five revolts. ${ }^{2}$ One such revolt was aboard the "Thomas" in $1797 .^{3}$ The women on board were released and let on deck to get exercise and eat. When they discovered that the armory was unlocked, they seized guns from this container and overpowered the crew. The men were then released and the ships eventually controlled by the captives. They were eventually recaptured because of their inability to navigate the seas (Beckles 1989: 155). But this incident was an early indication of women's unwillingness to accept their enslaved position.

\footnotetext{
${ }^{1}$ Camp, Stephanie M. H., Closer to Freedom: Enslaved Women and Everyday Resistance in the Plantation South, The University of North Carolina Press, 2004.

${ }^{2}$ Rediker, Marcus The Slave Ship: A Human History, Viking Publ., 2007.

${ }^{3}$ Ibid.
} 
Resistance history in the Caribbean and Americas in its various forms has always emphasized the role of men as leaders and heroes. Studies in the last two decades (Momsen 1996, Mintz 1996, Bush 1990, Beckles and Shepherd 1996, Ellis 1985, 1996, Hart 1980 and1985) however, are beginning to suggest the enormous contributions of women to the successes of many of the resistance events. Research revelations have been made about the negative impressions and images of enslaved women depicted in colonial writings (Mathis 2001, Beckles and Shepherd 1996, Cooper 1994, Campbell 1987, Price 1996). Some of these new findings depict women as being actively at the forefront of colonial military and political resistance operations as well as playing their roles as the bearers of their individual original cultures. One group of special interest in the Caribbean consisted of the women of the "runaway" communities as in Jamaica and Suriname, where the rich heritage of the contributions of such women continue to be significant. (Agorsah 1994, Craton 1982, Hart 1980 and1985, Zips 1999) Research done on the achievements of these communities does not often give much attention to the role and status of the women of those communities, except their role as housewives and bearers of children, with one notable exception- Nanny of the Maroons (or "Granny Nanny of Jamaica"). This inattention to the role and status of the women, is even more demonstrated by Werner Zips book, Black Rebels: African-Caribbean Freedom Fighters. While Zips' book is a significant contribution to the literature and study of the Jamaican Maroons, it still lacks the much-needed attention to the role of women, other than Nanny of Jamaica in the Maroon wars. Although Nanny certainly deserves the attention that 
Zips and other writers of Caribbean history gives to her, the fact of the matter is that there were other women who fought and resisted the bonds of slavery, just as Nanny did, but who have become "invisible women" throughout history. This is the case of the tale of the two Nannys - Nanny of the Maroons, Jamaica's sole official national heroine, and Nanny Grigg, who is described in the literature of the 1816 Barbados slave rebellion as a revolutionary ideologue. ${ }^{4}$ Both Nannys are described as militant women who led, physically and conceptually, their menfolk into violent confrontation with slave- owners and the imperial troops who defended them. ${ }^{5}$ Nanny of the Maroons was a guerrilla commander whose successes against pro-slavery forces in Jamaica are now legendary. The Barbados Assembly's official report into the 1816 rebellion describes Nanny Grigg as a literate, knowledgeable woman who believed and propagated the view that in order to secure freedom it was possible to replicate the Haitian Revolution. The report stated that she held considerable political authority among her male peers, and swayed them in favor of the armed solution to the slavery question (Mair, 1975a; Beckles, 1985).

Although both women were blessed with fighting spirits and military abilities, only Nanny of the Maroons is often credited as being a real and true heroine.

Leslie R. James (2000) in her review of Werner Zips’ Black Rebels states that, Zips' attempt to integrate so many dimensions of African Diasporic history resulted in certain areas being simply glossed over. His perspective, however, is a very interesting because of its attempt to give a synthetic

\footnotetext{
${ }^{4}$ Beckles Hilary McD, Historicizing Slavery in West Indian Feminisms, Feminist Review, No. 59, pp. 34-56; Rethinking Caribbean Difference (Summer, 1998); Palgrave Macmillan Journals.

${ }^{5}$ Ibid.
} 
view of Caribbean and African-American history. In the process regional differences are obscured... ${ }^{6}$

I would add that the mention of the role of women in these rebellions as indicated in others, was also glossed over or simply left out.

For slaves, life was harsh and harsher still for enslaved women. Enslaved men, in Antigua, for example most likely held non-agricultural and less arduous labor (Hector, 1996), and the women had to take the full brunt of the agricultural labor needs. From age 14 or 15 every enslaved woman, like the men, were assigned plots and were expected to produce no less than that of a man! Gender, differences in strength seemed to be of no account. Enslaved women bore the full weight of fieldwork, while they were excluded from the factory and other skilled work, and at the same time being excluded from the written annals of history books. Enslaved women also had to compete with poor white women as hucksters. The relationship between black and white female hucksters was complex, and was never far removed from legislative considerations. ${ }^{7}$ History reveals from as far back as the mid seventeenth century that Barbadian law makers designed legislation to prevent slave huckstering.

A 1774 law outlawed slave huckstering in “...in or about any of the streets, alleys, passages, or wharfs of any of the towns and on "any of the highways, broad-paths and bays...” “...Slaves found guilty of these offences were to be imprisoned and have their goods confiscated ...” (Beckles: 515-516) ${ }^{8}$

\footnotetext{
${ }^{6}$ James, Leslie R., Review of Werner Zips, Black Rebels: African-Caribbean Freedom Fighters, DePauw University, The North Star, Vol.3, no.2, Spring 2000.

${ }^{7}$ Beckles, Hilary, White Women and Slavery in the Caribbean, History Workshop, No. 36, Colonial and Post-Colonial History (Autumn, 1993), pp. 66- 82; Oxford University Press.

${ }^{8}$ Beckles, Hilary, An Economic Life of Their Own: Slaves as Commodity Producers and Distributors in Barbados in Gad J. Heuman and James Walvin, editors, The Slavery Reader, Volume 1, pp. 515-516, Routledge, 2003.
} 
He further saw this legislative provision of the eighteenth century, as an attempt to eradicate slave hucksters and penalize free hucksters. Unfortunately, the law took the side of the poor white women against black slave women. So it was that black slave women could not sell sugar, cotton, rum, molasses or ginger without written permission (Goveia, 1965:161-62). ${ }^{9}$ According to Beckles, these opportunities were left, in the main, for poor white women. Of special note is how specific these white minority, and therefore, discriminatory laws were. They also determined where black women could live and could not live, when they could be out of doors, and when they could not, whom they could be seen with and whom they could not. Their sub-humanity was enforced by law. But enslaved women in South Carolina didn’t let the 1866 law deter them from selling their products. This is seen in the story of the enslaved women who took control in the Charleston Market.

The Charleston Market was a place of tremendous activity. Farmers brought in their produce from the countryside. Fishermen hawked their catch. Peddlers sold bread and cakes. And at the heart of it all were the expert traders, who always got the best goods, knew how to corner the market on a highly desirable commodity and could set the prices that the public would have to pay for virtually everything in the market. These traders were Black women and they were enslaved.

\footnotetext{
${ }^{9}$ Goveia, Elsa V., Slave Society in the British Leeward Islands at the End of the Eighteenth Century. New Haven, CT: Yale Univ. Press, 1965.
} 
In the late 1600s, an enslaved woman in the Charleston, South Carolina area would often be sent to the market to sell her master's goods and buy what was needed for the home. Sometimes, she would arrange with her master to take the money from selling the goods, o buy other goods and resell them, making a larger profit. Out of the profit, she would pay her master a "wage," which remained the same no matter how much or how little she made. She would then keep the rest. ${ }^{10}$ Slaveowners liked this practice because they got a steady income from their slaves, regardless of what they had to sell or whether they had any work for the women to do.

Unfortunately, many other people didn't like it, because the women were very good traders. Soon, they had almost complete control of the city's food supply. In 1686, a law was passed forbidding the purchase of goods from slaves. ${ }^{11}$ But it had little effect. When an official marketplace was set up in 1739, part of its purpose was to prevent this kind of "black market" trading. That didn't work either. As it turned out, of the many attempts to take control of the marketplace out of the hands of enslaved Black women all failed. A petition presented to the Charleston assembly in 1747 describes the situation.

"[Their masters] give them all imaginable liberty, not only to buy and sell those commodities, but also, . . . to forestall the markets of Charles Town by buying up the Provisions, \&c. which come to town for sale, at dear and exorbitant prices, and take what other indirect methods they please, provided they pay their masters their wages, which they seldom or never enquire how they came by the same, ... [further] those Negroes and other slaves, being possessed of large sums of money, purchase quantities of flour, butter, apples, etc., all which they retail out to the inhabitants of Charles Town, by which means leading lazy lives, and free from the government of their masters."12

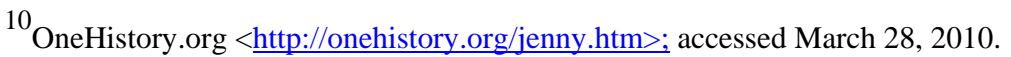

${ }^{11}$ Ibid.

${ }^{12}$ Ibid..
} 
The bottom line is that these women, using the skills of their foremothers in Africa, ruled the Charleston market, and some of them amassed considerable wealth in doing so. Even as being enslaved and women, they showed great resistance in the way they challenged white authority, which provided an example to other slaves.

But enslaved women were always the backbone of resistance in this and other Caribbean territories. Enslaved women filed more complaints in the courts than men. In Trinidad, for example, women were twice as likely as men to appear before magistrates as complainants; and women accounted for almost half the cases brought before Jamaican courts between 1835 and $1846 .^{13}$ In addition, enslaved women outnumbered men as offenders under Slave Laws. For example, in a Report on slaves in Guiana, the so-called Protector of Slaves in 1826 had this to say: "There is no question as far as has come within my reach of observation as to the difficulty of managing the women and they [the slave women] are irritating and insolent to a degree -- often instigated by the men -- to take advantage of the exemption from stripes and in town do little or nothing” (Hector, 1996).

Women in the Caribbean also played a large role in religious ceremonies and resistance resulting from religious practices. ${ }^{14}$ "Obeye” (or Obeah), the practice of

\footnotetext{
13 Black, Mindie Lazarus, "Slaves, Masters, and Magistrates: Law and the Politics of Resistance in the British Caribbean, 1736-1834,” in Contested States Law, Hegemony, and Resistance, Mindie Lazarus Black and Susan F. Hirsch, eds., New York \& London: Routledge, 1994.

${ }^{14}$ Giraldo, Alexander, Obeah: The Ultimate Resistance, http://scholar.library.miami.edu/, online, 2007, available at: $<\underline{\text { http://scholar.library.miami.edu/slaves/Religion/religion.html }>}$
} 
harnessing supernatural forces and spirits for one’s own personal use (originated in Africa), was one of the rituals used in the Caribbean islands and it took on many names, such as "Shango" in Trinidad, "Ju-Ju" in the Bahamas, and "Obeah" in Jamaica. ${ }^{15}$

Although this practice was generally used by slaves for evil or self-interested instrumental purposes, it was also a source of strength and a form of resistance from their colonial oppressors, specifically in slave rebellions. ${ }^{16}$

\section{Slavery and Trade in the Caribbean}

Spanish explorers of the Caribbean were searching for the Far East. Though unsuccessful, they did find evidence of gold among the Taíno people of the Greater Antilles. This ensured they would stay, overcoming resistance by the Taíno and the Kalinago (also known as the Carib) people by the beginning of the 16th century AD. ${ }^{17}$ The native people were enslaved and forced to work in the mines and on the profitable sugar plantations that were soon established. Loss of culture, brutal working conditions and European diseases soon devastated the Taíno and the Kalinago population. ${ }^{18}$

To replace native workers, the Spanish imported captured African slaves. By the mid-17th century, the British had taken Jamaica from the Spanish and controlled other smaller islands. They too imported African slaves to work large estates, as did the French

\footnotetext{
${ }^{15}$ Giraldo, Alexander, Obeah: The Ultimate Resistance, http://scholar.library.miami.edu/, online, 2007, available at: $<$ http://scholar.library.miami.edu/slaves/Religion/religion.html>

${ }^{17}$ Tremlett, Giles, “Lost Document Reveals Columbus as Tyrant of the Caribbean” ; The Trinidad Guardian, August 7 , 2006.

${ }^{18}$ Morris, Glenn, Native American professor at the University of Colorado, Denver; and a member of AIM (American Indian Movement), from a teach-in he held on 01/13/07.
} 
who ruled several islands. By the time the Atlantic slave trade was abolished in 1834, it was estimated that 4.7 million slaves were forcibly brought to the islands and the Guianas in South America. The last trace of slavery in the West Indies was abolished in the 1870s.

Throughout this period there were numerous slave revolts, such as the successful 1791 uprising in Haiti. Despite horrendous conditions, enslaved people from different cultures in Africa preserved much of their religious beliefs and cultural traditions that in turn contributed to a new West Indian society. In Appendix “A” is a list of resistance and rebellions in Trinidad and Tobago during the period of enslavement.

\section{Aspects of Women's Resistance}

Textbooks, in American schools in particular, usually combine the story of male and female slaves into one history when relating the accounts of African American slavery and have hardly ever helped students understand the challenges of women constrained by the institution of slavery. Letters and autobiographies of enslaved women in the nineteenth century, now available in many sources, including the internet open windows into the experiences of these women, and provide teachers and students the opportunity to explore this history. One such resource is the quarterly online journal, History Now: American History Online, by the Gilder Lehrman Institute of American History. Even in today's elementary through high schools, students still accept (and what's worse, are encouraged by their teachers to accept) everything that they read in history books as "the truth". Teachers often hear, "Well, I read it in the book. It must be 
true." or "It was on the news, in the newspaper, or in a magazine." I certainly wasn’t exposed to any of what I've learned since returning to higher education, when I was in junior high and high school. Unfortunately too many students hear teachers say that if it's in the book, then it must be so.

\section{Women at the Beginning}

Much of what has been called history has been recorded by men of the dominant culture of that society.

So when the woman saw that the tree was good for food, and it was a delight to the eyes, and the tree was to be desired to make one wise, she took of its fruit and ate; and she also gave some to her husband, and he ate. $^{19}$

[Heracles] found in a cave a creature of double form that was half damsel and half serpent; above the buttocks she was a woman, below them a snake. $^{20}$

The youngest daughter, Libuše, was the most marvelous of the three . . .: wise in council, powerful in speech, chaste in body, outstanding in morals, second to none in her concern for justice, affable to all, a glory and decoration of the female sex....But, since no one is in every way good, this praiseworthy woman —oh sad human estate-was a seer. ${ }^{21}$

Heli begat Joseph; Joseph begat Joachim; Joachim begat Mother Mary, Mother of the Lord Jesus Christ. ${ }^{22}$

The above texts which span over a thousand years of time, have one major thing in common - their author, all men, are writing about the beginnings: the beginnings of

\footnotetext{
${ }^{19}$ Genesis 3:6.

${ }^{20}$ Herodotus, 4.9 .

${ }^{21}$ Cosmos of Prague, Chronica Boemorum, 1.4, Comos von Prag, Die Chronik der Böhmen, ed. B. Bretholz, MGH Scriptores rerum Germanicarum, Nova series 2 (berlin, 1923), p. 11.
} 
peoples, of families, of nations, of religions. They also share in common a need to fix the place of women in these beginnings, ${ }^{23}$ as well share in common a need to fix the earliest accounts of peoples in Herodotus, to the genealogies in sacred scripture and later religious traditions, to legends of the founding of ancient cities, to early medieval accounts of the peoples who displaced Roman political authority in the West, to noble families' genealogies constructed in the eleventh century and beyond. Women, while present, played usually at best, a marginal role. ${ }^{24}$ Some are but names; wombs that make possible the transmission of male virtue from generation to generation. Prominent women are often distinguished by their wickedness. Women such as Dido and Eve, some medieval Islamic versions of Sarah, are the source of sin and conflict. ${ }^{25}$ This was even more evident in a gospel homily given by Father James Mayo of St. Michael the Archangel Church in Portland, Oregon on Sunday, March 31, 2010:

... but Jesus went to the Mount of Olives. 2 Early in the morning he came again to the temple. All the people came to him, and he sat down and taught them. 3 The scribes and the Pharisees brought a woman who had been caught in adultery, and placing her in the midst $\mathbf{4}$ they said to him, "Teacher, this woman has been caught in the act of adultery. $\mathbf{5}$ Now in the Law Moses commanded us to stone such women. So what do you say?” 6 This they said to test him, that they might have some charge to bring against him. Jesus bent down and wrote with his finger on the ground. 7 And as they continued to ask him, he stood up and said to them, "Let him who is without sin among you be the first to throw a stone at her." 8 And once more he bent down and wrote on the ground. 9 But when they heard it, they went away one by one, beginning with the older ones, and Jesus

\footnotetext{
${ }^{22}$ Liber genealogues, ed. Heodor Mommsen, MGH AA 9, Chronica Minora saec IV.V.VI.VII (Munich, 1981), p. 194.

${ }^{23}$ Geary, Patrick J., Women at the Beginning: Origin Myths from the Amazons to the Virgin Mary, Princeton University Press, 2006.

${ }^{24}$ Ibid.

${ }^{25}$ Ibid.
} 
was left alone with the woman standing before him. 10 Jesus stood up and said to her, "Woman, where are they? Has no one condemned you?" 11 She said, "No one, Lord." And Jesus said, "Neither do I condemn you; go, and from now on sin no more. "26

Father Mayo’s question to us parishioners was: "Where is the Bozo (the man) who was with the woman helping her commit adultery?"27 I too, started to wonder about that famous biblical story. Yes, where was the man? And why is he never mentioned or brought before the accusers in this story? The man is now the "invisible" one, and the woman, who has been pinpointed as a sinner and adulterer, is now quite visible in this historical text.

The men who wrote about these women held ambivalent attitudes towards them, attitudes that are evident in the contradictory images produced and reproduced across centuries. $^{28}$ Geary posits that the representation of women in stories of beginnings, as Amazon or saints, monsters or troublemakers, are too complex to categorize. They remain problematic and contradictory figures. And yet they continue to fascinate, to tempt us to consider them, to ask what the place of women at the beginning tells us about women, about beginnings, and about the present and the future. (Geary, p. 4)

Geary goes on to say that whatever may have been the complex roles of women in classical societies; women in the origin accounts came to us firmly in the control of

\footnotetext{
${ }^{26}$ John 8:1-11, New American Bible, United States Conference of Catholic Bishops.

${ }^{27}$ Mayo, Father James, St. Michael the Archangel Church, Portland, Oregon, Gospel Reading and Homily, Sunday, March 21, 2010; John 8:1-11.

${ }^{28}$ Geary, Patrick J., Women at the Beginning: Origin Myths from the Amazons to the Virgin Mary, Princeton University Press, 2006.
} 
masculine ideological agendas. And that if present at all, women at the beginning tended to die violently so that proper male civilization could develop.

The essays in Geary’s book attempt to answer questions such as whether or not literary texts gave evidence that women became progressively silent, marginalized in society, and virtually irretrievable to history. However, as historians continued to study women during the Middle Ages, it became evident that women began to gain prominence in public life. Thus, unable to eliminate women from the practice of public power, the writers chose to eliminate them from the only world over which they had full control: the world of texts - historical texts. (Geary, p. 6)

Scholars are pretty much in agreement that the men who wrote the texts decided what should be recorded and what is important. So there is little written about women, and still less about minority women. However, that is slowly changing with many minority women writers that are flooding the academic world with the stories and histories of all women. This is very good, since many students have deduced that since women and members of minority groups rarely appear in history texts, they contributed little (or even nothing) to history.

Dr. Mary Pipher, a psychotherapist and New York Times best-selling author for her book, Reviving Ophelia: Saving the Selves of Adolescent Girls (1995), says that when girls and women read a history of Western civilization, they are essentially reading a record of men’s lives. Pipher quotes Dale Spender, author of Man Made Language (1980; 1985), “Women's accomplishments are relegated to the lost and found.” As girls 
study Western civilization, they become increasingly aware that history is the history of

men. History is His Story, the story of man-kind. Pipher goes on to say,

"I discovered this when I read H.G. Well's Outline of History and Winston Churchill's History of the Western World. Both are primarily histories of war and the distribution of property. Women's lives were ignored except as they influenced the course of men's lives. I remember, Pipher continues, wondering "where were the women during all these events?" My daughter made the same observation about her history text: "It's so boring, just a bunch of kings and generals fighting each other. What were the women doing anyway?"29

Girls move into a culture with a Constitution that gave white men, not all

Americans, the right to vote, and that has yet to pass an equal rights amendment. They (girls) join a culture in which historical documents proclaim the rights of man. As the writer and poet, Tillie Olsen observed, “Women’s voices have been silenced through the ages, and the silencing continues in the present.” (Pipher, 40-41). Pipher notes that by junior high, girls sense their lack of power, but usually they cannot say what they sense. "If I ask who writes most of the material they study at school, they know it's men. If I ask who is more likely to be principal, they say a man. If I ask who has the most power, they say men. Girls should be encouraged to think about these issues and bring me examples of discrimination.”

One girl noticed that the mountains in Colorado that were named for men had their last names. She brought in a map to point out Mount Adams, Mount Audubon, Babcock Peak, Mount Sneffels, and Mount Richtofen. The few natural features that are named for women are named with only the women’s first name, such as Mount Alice,

\footnotetext{
${ }^{29}$ Pipher, Mary, Reviving Ophelia: Saving the Selves Of Adolescent Girls, Ballantine Books, 1995.
} 
Mount Emma, Mount Eva, Lake Emmaline, Lake Agnes, Maggie Gulch, and Mount Flora (p. 41).

\section{RESEARCH QUESTIONS}

Some crucial questions addressed in this research include: Who were the major contributors in the selected resistance episodes in the selected areas such as: the January 7, 1876 Belmanna Riots on the Roxborough Estate in Tobago; the St. John Slave Rebellion of 1733 (St. John, U.S. Virgin Islands); the St. Croix Labor Revolt of 1878 also known as the Fireburn (St. Croix, U.S. Virgin Islands); the 1892 Coal Worker Strike (Coal Carrier's Strike) on St. Thomas, U.S.V.I., and the 1816 Slave Rebellion in Barbados? How did they relate to the events politically, socially, militarily and economically? What exactly were their contribution and impact of those contributions? Were the women involved in the Black Power Movement in both the Caribbean and USA, only doing so in order to follow the men around, and did they look at these men as celebrities, thus, conducting themselves as groupies as opposed to women in the fight for justice and equality? Was the Civil Rights Movement in the U.S essentially built and operated by men, such that the role performed by women need only be remembered as a footnote in history?

This study aims to demonstrate that many of the more obscure (or lesser-known) female personalities in resistance movements have been overlooked and understudied by historians. Although research has been done of the achievements of many of the enslaved communities, not much attention has been given to the role and status of the 
women of those communities, except their role as housewives and bearers of children. It is clear that further research needs to be done to fully examine the more important roles of the more obscure women that have simply been left out of history. In addition to examining these roles, the study will also examine certain similarities in personalities and strategies used by women among these communities as they headed toward the achievement of equality. Trinidad and Tobago, the U.S. Virgin Islands, Jamaica, and southern United States will be the initial geographical areas of focus. Aspects of women’s spirituality as vehicle as well as weapon and its impact on the resistance activities will are also investigated.

Results of this study should help to explain that although there were many horrors witnessed by the women of these resistance movements, there were a large number who made it and contributed substantially to the labor force on the plantations, especially on the Caribbean sugar plantations. Although women exhibited considerable rebelliousness to the slave system, the nineteenth century women actually exceeded male slaves when it came to work and value (Beckles, 1989: 32). Enslaved women were the dominant force behind production and labor reproduction. The hardships of slavery and the coinciding opposition to the system helped to mold the Caribbean woman into what she is today. Rhoda Reddock, puts it even better in an excerpt from Women, Labor and Politics in Trinidad and Tobago:

"Despite the treachery and inhumanity of the plantation experience it brought to the fore the potentials for production, self-sufficiency, rebellion, and the relentless quest for personal autonomy still present in Caribbean women today.” (Reddock, 1994: 11) 
The list is endless. Probably due to a large extent because of their skin color and to a certain extent because of their gender, there are many other great "queens" or rather, women of African descent, who have unfairly been denied the utmost veneration and great honor they deserve. Among the many are those listed below in Appendix "B". Archival records from plantations located in archives and county clerks' offices; interviews with sources familiar with the plantations of slave communities in designated areas; and research in libraries, as well as other sources. In addition, interviews with sources familiar with the lives of individuals in post-slavery Caribbean and USA will be used. 


\section{CHAPTER 2}

\section{PREVIOUS RESEARCH}

This chapter reviews past studies on the role of women during the slavery period and how those past endeavors relate to my current study of women in resistance. Running away from the harshness of the fields, the masters and the overseers is what was taught in junior high and high school history books. There was no discussion of other forms of resistance to slavery that discussed both male and female slaves on equal levels. Acts of murder, though not common, were also said to have been committed by black women against their white oppressors. According to some writers in the last half century, women have also been found to figure prominently in such events as suicides and mass poisonings (Klein, 1986: 94).

According to Barbara Bush (1990), who provided a lot of information of first person accounts in her book, Slave Women In Caribbean Society 1650-1838, treatment of women in slavery was always more serious and degrading. Bush touches on topics of slave women in resistance, as transmitters of African culture, and also as crucial parts of

the labor force. In Bush’s study, new revelations regarding the female slave in Caribbean society were uncovered, which included: the vital and significant contribution she (the enslaved woman) made to West Indian slave society; how she exhibited strength and independence which wasn't previously accredited; how she struggled alongside her men- 
folk to live, maintain her dignity, to survive, and retain her integrity and culture; and her positive role in slave resistance.

My study is very much aligned with Bush’s, and will help shed additional light on women's roles, and my study will focus more on the lesser-known women resistance leaders in both the Caribbean and the USA, and will carry Bush’s study further by redefining and correcting the misconceptions about women during the period of enslavement, as well as identify those who have been left out of history altogether-those I refer to in my study as the lesser-known women in slavery and slave resistance.

Pero Gaglo Dagbovie notes in an article, Black Women, Carter G. Woodson, and the Association for the Study of Negro Life and History, 1915-1950, that "Woodson (an African American historian who first opened the long-neglected field of black studies to scholars and also popularized the field in the schools and colleges of blacks; edited the first issue of the association's principal scholarly publication, The Journal of Negro History, which, under his direction, remained an important historical periodical for more than 30 years; and was dean of the College of Liberal Arts and head of the graduate faculty at Howard University in Washington, DC ) lacked background for broad historical writing; was almost contemptuous of emotion; he had limited human contacts and sympathies.”30 But several months after his death, W. E. B. Du Bois concluded this

\footnotetext{
30 Dagbovie, Pero Gaglo, Black Women, Carter G. Woodson and the Association for the Study of Negro Life and History, 1915-1950, The Journal of African American History, Winter, 2003, vol. 88, no. 1, p. 21-41.
} 
harsh criticism of the founder of the Association for the Study of Negro Life and History (ASNLH) adding:

"he had no conception of the place of woman in creation.",31

It is thought that Du Bois was criticizing Woodson for supposedly ignoring black women's role in history. Patricia Morton's study is admirable as discussed in Disfigured Images: The Historical Assault on Afro-American Women (1991) and used in courses such as “Black Women Images”. Almost four decades after Woodson's death, Morton elaborates on Du Bois's provocative comment that starting in the nineteenth century and well into the second half of the twentieth, many black male historians have contributed to White society's most detrimental views, myths, and stereotypes of black womanhood. Though she notes that Woodson at times defended black womanhood, she stresses that the "Father of Negro History” largely omitted slave women and black female activists from his work. At the same time, she praises Woodson for challenging “conventional orthodoxies,” specifically for deconstructing some of the myths pertaining to black women.” (Woodson, pp. 270, 272). ${ }^{32}$

Woodson's views of black women may appear to have been at times ambiguous, but overall, they were quite progressive compared to other black male scholars and historians of his time. While he did not publish monographs devoted to black women or

\footnotetext{
${ }^{31}$ Dagbovie, Pero Gaglo, Black Women, Carter G. Woodson and the Association for the Study of Negro Life and History, 1915-1950, The Journal of African American History, Winter, 2003, vol. 88, no. 1, p. 21-41.

${ }^{32}$ Carter G. Woodson, "The Negro Washerwoman, A Vanishing Figure," Journal of Negro History, July 1930, pp. 270, 272.
} 
fight actively and openly for women's rights, he did publish several important articles in the 1930s which sought to reconstruct the prevailing negative images of black womanhood. ${ }^{33}$ He welcomed black women with open arms into a movement very dear to him, and he also supported and celebrated their efforts at legitimizing and popularizing the study of African American life and history. Black female teachers, club-women, librarians, amateur historians, and social activists played vital roles in the activities of the ASNLH. However, he did not include the lesser-known women, but my work will expand on his work.

Verene Shepherd (1999) notes in the Introduction of Women in Caribbean History, that until the 1970s, Caribbean history books contained very little information about women. Some of the reasons, according to Shepherd, were 1). that the main focus of the early historians was on issues relating to colonization, government, diplomacy, religion, trade and warfare. Men were considered and depicted to be more involved in these activities than women; 2). Some historians, including Carter G Woodson, did not think that women's issues merited inclusion in history books; therefore they did not write about the history of women apart from those who were great leaders or were involved in 'public' life; 3). Social history techniques had not yet become widely used in the writing of Caribbean history. Social history was considered to pay more attention to groups which were not of the elite class and to topics such as family and reproduction - not at

\footnotetext{
${ }^{33}$ Carter G. Woodson, "The Negro Washerwoman, A Vanishing Figure," Journal of Negro History, July 1930, pp. 270, 272.
} 
first considered suitable or important topics for history textbooks; and 4). Many historians opted to write what they regarded as 'gender neutral' history, believing that this was a more objective way of writing history. My work will pay attention these issues especially as they relate to resistance and to the lesser-known women.

Shepherd goes on to say that the factors that contributed to a change in the subjects chosen for history included: the slow acceptance of the methods of social history; the influence of the international women's movement with its attention to women's rights; the emergence of 'women's history' ('women's history’ challenged the claim that only men should be written about and writers of women's history argued that our view of history would change if women were included in the historical accounts); the emergence of a group of demographic and social historians concerned with Caribbean women's history; and the need to project a more positive image of Caribbean women, especially black women; because stereotypes and negative images of Caribbean women abounded in the journals of Columbus, the books written by the early colonizers and settlers, travelers, missionaries and others who visited the Caribbean in that period. Writers who have contributed much to overturning the negative images of Caribbean women and increasing our knowledge of the history of the Caribbean women include pioneers such as Elsa Goveia (1965), Lucille Mathurin-Mair (1975), Barry Higman (1984) and Kamu Brathwaite (1977). More recently we have benefitted from research perspectives of people like Rhoda Reddock, Hillary Beckles, Barbara Bush (both who have been mentioned earlier), and Marietta Morrissey (1989). But Shepherd 
cautions that the current research still does not reflect the historical experiences of all groups of women in the Caribbean (Shepherd, 1999: xix).

In conclusion, as can be observed from these past research endeavors, a new approach and perspective on the history and culture of the enslaved has now recognized significant roles of women in the historical unfolding of the colonial encounter. But the coverage appears to still be incomplete in the sense that, like colonial writings, attention has been focused on only the more prominent and obvious women personalities involved. My research will extend the coverage to include the less well-known individuals but equally effective women and their role in the achievement of freedom and equality and the fight against colonial oppression. They appear to be the forgotten women pioneers who, by their deeds have passed down their legacies to generations. For some reason, the fact that they were forgotten provided some of their families to survive behind the scenes until today. As the research of this thesis will indicate, they have carried the true picture of the true nature of the struggle from oppression in the stories they tell. This is the additional dimension that my thesis brings to our understanding of women in resistance in the New World. In addition, these stories confirm that the struggle is not yet over, because current evidence demonstrates that vestiges of the colonial experience appears to remain in some sectors of society. As the story unfolds, it would be realized that there is much more historical evidence about the history and role of women in the Americas than is commonly assumed. 


\section{CHAPTER 3}

\section{WOMEN OF SPIRIT, RESISTANCE AND STRENGTH, 17th -- 20th CENTURY}

This chapter discusses selected women who played major roles in resistance during the colonial period. The history of each is examined and the significance of the their roles is discussed to show the contribution of women, working, as it were, behind the scenes towards freedom and self-determination.

\section{The Caribbean - Haiti}

Queen Anacaona (1464 - c. 1504 ; Hispaniola)

Called the Golden Flower, Anacaona was celebrated as a composer of ballads, poems and narrative. She was a Taino Queen as well as Chief in Hispaniola when the Spaniards settled there in 1492. She refused to be enslaved and died fighting for the liberty of her people.

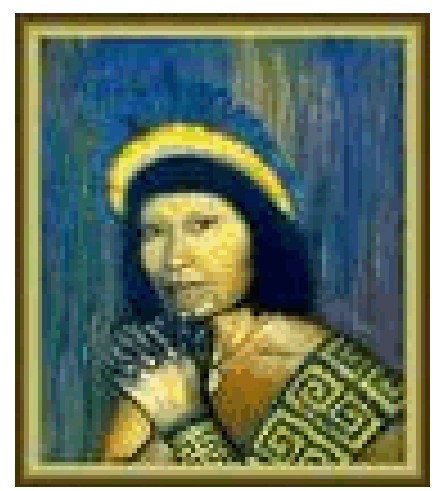

During Columbus's visit to the chiefdom of Xaragua in the southwest of Hispaniola (modern day Haiti) in late 1496, Anacaona and her brother Behechio appeared as equal negotiators. ${ }^{34}$ Columbus successfully negotiated for tribute that consisted of food and cotton for the struggling Spanish settlers under his command. Several months later, Columbus arrived with a caravel to collect a part of the tribute.

\footnotetext{
${ }^{34}$ Wikipedia Contributors. “Anacaona”, Wikipedia, the Free Encyclopedia. Wikipedia, the Free Encyclopedia, 23 Jun. 2010. Web. 12 Jul. 2010.
} 
Anacaona became queen of Xaragua after her brother's death. Her husband Caonabo, suspected of having organized the attack on La Navidad (Spanish settlement on northern Haiti), was captured by Alonso de Ojeda and shipped to Spain, dying in a shipwreck during the journey. ${ }^{35}$ As kind as Anacaona and her people were to Columbus and his men, the Taínos were ill-treated by the conquerors. They soon revolted and made a long war against the Spaniards. During a feast organized by eight regional chieftains to honor Anacaona, who was friendly to the Spaniards, Spanish Governor Nicolás de Ovando ordered the meeting house set on fire. He arrested Anacaona and her Taíno noblemen, all of whom, being accused of conspiracy, were executed. While others were shot, Anacaona was instead hanged at the age of 29.

\section{The Caribbean - Jamaica}

Nanny of the Maroons (c. 1700-1740)

Known as Jamaica’s True Queen, (Gabriel, 2004)

Nanny of the Windward Maroons is credited with being the single figure that united the Maroons across Jamaica as well having played a major role the preservation of African

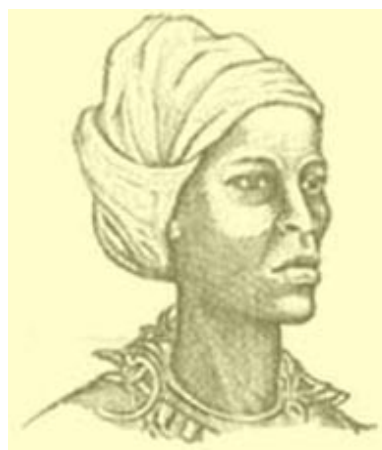
culture and knowledge. Yet many say that Queen Nanny has largely been ignored by historians who have restricted their focus to male figures in Maroon history. However, among the Maroons themselves she is held in the highest esteem.

\footnotetext{
${ }^{35}$ Hatiti Support Group Web Site, Famous Haitians; Accessed April 20, 2010, http://www.haitisupport.gn.apc.org/10_fam_main.html\#ptop
} 
The biographical information on Nanny isn’t all that clear, with her being mentioned only four times in written historical texts and usually in somewhat derogatory terms. ${ }^{36}$ However, she is held up as the most important figure in Maroon history by not only the people of Jamaica, but by historians and scholars worldwide. She was the spiritual, cultural and military leader of the Windward Maroons and her importance stems from the fact that she guided the Maroons through the most intense period of their resistance against the British, between 1725 and 1740.

Queen Nanny is presumed to have been born around the 1680's in Africa's Gold Coast (now known as Ghana). ${ }^{37}$ She was reported to belong to either the Ashanti or Akan tribe and came to Jamaica as a free woman. As she is reportedly of royal African blood, some historians believe that it is possible that Queen Nanny bought slaves of her own, as it was not uncommon for African dignitaries to keep slaves. ${ }^{38}$

As it is well documented, on the plantations women did not escape the brutality of slavery. Marriage and partnerships among slaves were often prohibited. For those that managed to form unions in secret, they were forced to endure the removal of their offspring who were separated from their mothers soon after birth and sold into slavery. Many women opted for abortions rather than see their babies endure the same fate (slavery) that had befallen them. Furthermore, women on the plantations were physically

\footnotetext{
36 Gabriel, Deborah, Jamaica's True Queen: Nanny of the Maroons, September 2, 2004, http://www.jamaicans.com/articles/primearticles/queennanny.shtml

IslandMix Forums, Jamaica's True Queen: Nanny of the Maroons, November 20, 2005. http://www.islandmix.com/backchat/f27/jamaica-s-true-queen-nanny-maroons-110238/ ${ }^{38}$ Ibid.
} 
exploited by their slave masters by rape and other sexual practices that were often quite sadistic. They too endured hard physical labor within the household doing domestic work and rearing the children of their slave masters. Many worked on the plantation itself.

By contrast, Maroon women raised crops and were responsible for most of the agricultural output within their communities. The men are said to hunt wild hogs and raided the plantations for food and supplies and to free slaves. Often, the plantations were 'raided' to bring back women into the Maroon communities, without which they would be unable to increase their numbers and ensure the survival of the Maroons as a race. There are legends of great women Maroon warriors, who raided the plantations and freed slaves, wielding huge knives that they used to cut off the heads of the British. The strength of women in Maroon communities stemmed from their position within traditional Ashanti or Akan culture. The Ashanti culture was based on a tradition of warrior nations and a history of proud and respected women. And many Ashanti elements were retained in Maroon language and culture in Jamaica.

Queen Nanny is credited with being the military leader of the Windward Maroons (Hart, 1985; Brathwaite, 1994) who employed clever strategies which led to their repeated success in battles with the British. She was a master of guerilla warfare and trained Maroon troops in the art of camouflage. Oral history recounts that Nanny herself would cover her soldiers with branches and leaves, instructing them to stand as still as 
possible so that they would resemble trees. As the British soldiers approached completely unaware that they were surrounded they would swiftly be picked off by the Maroons. ${ }^{39}$

Maroon settlements were sited high up in the mountains with only a narrow path leading to their town (Agorsah, 1992 and 1994). In this way, the British soldiers could clearly be seen on approach as they advanced in single file, allowing them to be picked off one by one. This method was particularly successful with large numbers of British soldiers being killed by a comparatively small number of Maroons.

A famous legend about Queen Nanny (Brathwaite, 1994) is that during 1737 at the height of the Maroon resistance against the British, Nanny and her people were near starvation and she was on the brink of surrender, when she heard voices from her ancestors telling her not to give up. When she awoke she found pumpkins seeds in her pocket which she planted on the hillside. Within a week the seeds grew into large plants laden with pumpkins that provided much needed food for the starving community. To this day, one of the hills near Nanny Town is known as 'Pumpkin Hill' ${ }^{40}$

There are two versions of the story of Nanny catching bullets (Gabriel, 2004; Brathwaite, 1994). The first is that Queen Nanny was able to catch bullets with her hands, which was a highly developed art form in some parts of Africa. The other story is that Nanny was able to catch bullets with her buttocks and fart them out again. Renowned historian Edward Braithwaite (1994) suggests that the original story took a vulgar twist

\footnotetext{
${ }^{39}$ Gabriel, Deborah Jamaica's True Queen: Nanny of the Maroons, September 2, 2004 http://www.jamaicans.com/articles/primearticles/queennanny.shtml

${ }^{40}$ Ibid.
} 
on account of British colonialists who were known to detest Nanny and were being deliberately offensive about her when they relayed this tale. ${ }^{41}$

The last legend about Queen Nanny is that she placed a large cauldron on the corner of a narrow mountain path near the edge. The pot was said to be boiling even though there was no fire beneath it. British soldiers approaching would curiously look inside, fall in and die. Some were said to collapse and fall over the hill. There have been suggestions that the pot contained special herbs with anaesthetic properties, as Nanny was said to be an herbalist. Contemporary historians maintain that the pot was in fact a circular basin formed by the hollowed out rocks of the Nanny River, joined by the waters of the Stony River. The continuously flowing river kept the water constantly frothy, giving it the appearance of a boiling pot. ${ }^{42}$

Queen Nanny was hated by the British, and early historians wrote in derogatory terms about the Maroons, trying to present them as savages no better than animals. She was often portrayed as being bloodthirsty. Thickness’ journal published in 1788 described an encounter with a woman presumed to have been Nanny herself, wearing bracelets and anklets made from the teeth of British soldiers. "The old hag had a girdle around her waist with nine or ten different knives hanging in sheaths to it, many of which I have no doubt have been plunged in human flesh and blood".

\footnotetext{
${ }^{41}$ Gabriel, Deborah, Jamaica's True Queen: Nanny of the Maroons, Jamaicans.com, September 2, 2004, http://www.jamaicans.com/articles/primearticles/queennanny.shtml.

42 Ibid.
} 
Much of the work compiled by Edward Braithwaite was instrumental in seeing Queen Nanny made a National Hero of Jamaica in 1976.This brought about a national recognition of the contribution made by the Maroons in securing liberty from slavery from the British.

The Windward Maroons with Queen Nanny as their leader are role modelS for resistance, rebellion and survival. Queen Nanny herself is a symbolic figure for all those who suffer from oppression. Whilst Queen Elizabeth 1 dispatched the pirate John Hawkins on her own ship, the SS Jesus of Lubeck to Africa with orders to transport Africans to Jamaica, Nanny of the Windward Maroons was empowering her people to resist enslavement at all costs. Therefore, Queen Nanny is the true Queen of Jamaica.

Jamaica as an independent country has accorded proper respect to the Maroons. Their leader "Queen Nanny" appears on the 500 dollar bill that is in circulation in Jamaica today. Nanny was herself an escapee from slavery along with her brother Cudjoe, who led raids against plantations to free slaves. Although her birth date is not known, it is

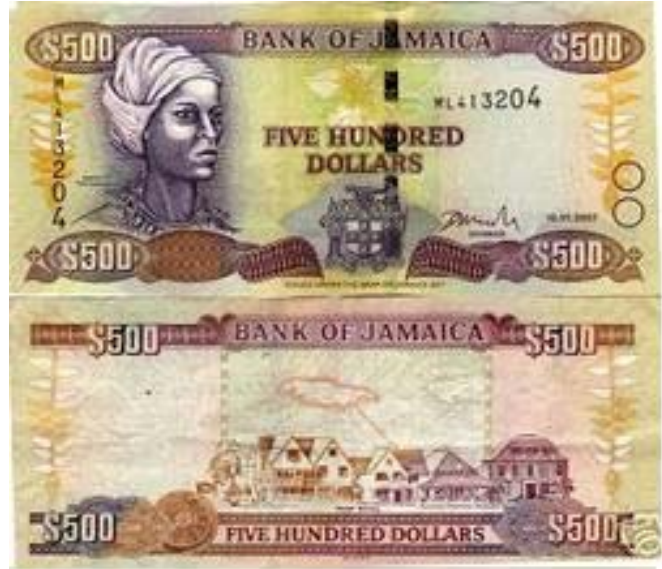
inferred from historical records that she was born in the 1600's. Queen Nanny, who reputed to be a practitioner of magic somewhat comparable to Voudun or Santeria. She never returned escaped slaves and is in fact credited with aiding in the escape of about 
800 slaves during her lifetime. Nanny's tragic death and betrayal is documented as

follows in the "Journal of the Assembly of Jamaica."

"In the Journal of the Assembly of Jamaica, 29-30 March 1733, we find a citation for "resolution, bravery and fidelity" awarded to "loyal slaves . . . under the command of Captain Sambo," namely William Cuffee, who was rewarded for having fought the Maroons in the First Maroon War and who is called "a very good party Negro, having killed Nanny, the rebels (sic) old obeah woman" (quoted in Campbell 177). These hired soldiers were known as "Black Shots" (Campbell 37). Some scholars raise the possibility that more than one leader named Nanny existed, along with the possibility that Cuffee was lying to get a reward, this gives us an approximate death date for Nanny of the Maroons.

Considering the use of the word "old," we can only assume that Nanny was born in the seventeenth century." (Edwards, vol. 1, page 525). ${ }^{43}$

She was said to be married to a man named Adou, but had no children. She died in the 1730's.

\begin{tabular}{|l||}
\hline \multicolumn{1}{|c||}{ Mystical Queen of the Maroons } \\
Blue Mountain rebel, Caribbean queen \\
All of Jamaica claims you their own. \\
Obeah woman, both seen and unseen \\
Great military leader of Nanny Town. \\
An Ashanti leader, the story tells \\
Of your great stand of Pumpkin Hill \\
Mystic woman, casting great spells \\
No enemy was safe, you demanded free will. \\
Maroon leader, born so at birth \\
Your story is still told to all \\
Dominate, vicious, salt of the earth \\
Your supernatural gifts caused many to fall. \\
Resistant from the beginning, more in the end \\
No English raider could withstand \\
Your punishing spirit, the hill you still defend \\
Affirming the freedom of the land. \\
Clare J. Washington, C11/12/09
\end{tabular}

\footnotetext{
${ }^{43}$ Edwards, Bryan, History, Civil and Commercial of the British Colonies in the West Indies, 1793.
} 


\section{The Caribbean - Haiti}

Women of the Haitian Revolution (1791-1804)

Sanite Bélair, Catherine Flon, Marie Jeanne Lamartiniere, Claire Heureuse, Ezili Dantó, Henrietta Saint-Marc (Henriette de Saint-Marc)

\section{The Heroes --}

Toussaint Louverture, Jean Jacques Dessalines, Henry Christophe, Alexandre

Petion.

\section{The Heroines -}

Sanite Belair, Catherine Flon, Marie Jeanne Lamartiniere, Claire Heureuse, Henriette de St. Marc.

Much history has been written about Toussaint Louverture and the other male heroes of the Haitian Revolution, but there were Haitian women whose names should be remembered as revolutionary women, and who played key roles in the revolution as well. They include: Marie Claire Heureuse Dessalines, Sanite Belair, Catherine Flon, Henriette St-Marc, Dede Babile, Marie Jeanne, Toya, Cecile Fatima, Suzanne Louverture, and Marie Louise. I write about two of the most prominent women - Suzanne "Sanite” Bélair and Catherine Flon.

$$
\text { Suzanne “Sanite” Bélair (1781?- }
$$

1802) was the equivalent of a Sergeant in the Haitian revolutionary forces led by Toussaint Louverture against the French

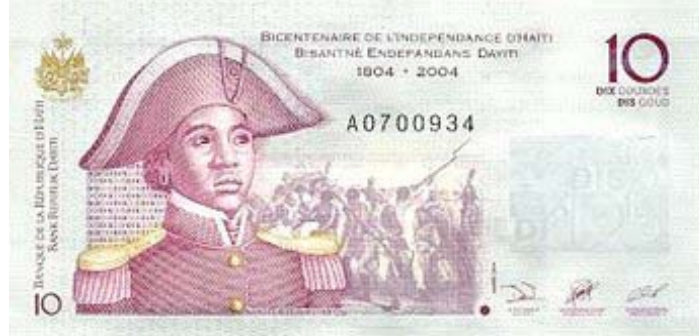


colonial government. In 1796 she had married Charles Bélair, ${ }^{44}$ who fought with Toussaint as a Brigade Commander and later as a General. She was executed by a firing squad by the French on the same day as her husband, Charles, was also shot. After being taken captive in 1802 while fighting the troops of French General Leclerc, Charles Bélair in an effort to rejoin Sanite, turned himself over to the captors. They were brought to Le Cap and condemned to death. Because she was a woman, the captors insisted on a different mode of execution for her and her husband Charles. Sanite Blair was to be decapitated and Charles to be executed by firing squad. She refused to die like a common soldier and watched her husband die. He had spoken to her in a calm voice asking for her to die bravely. ${ }^{45}$

Sanite Bélair refused to be blindfolded and succeeded to have an execution in the same manner as her husband. She is regarded as one of the great heroes of the independence struggle as well as one of the countless important women, without which the Haitian Revolution could not have successful, leading to independence and freedom from slavery in $1804 .^{46}$

Catherine Flon was the goddaughter of Jean-Jacques Dessalines. She sewed the first Haitian flag on May 18, 1803 on the last day

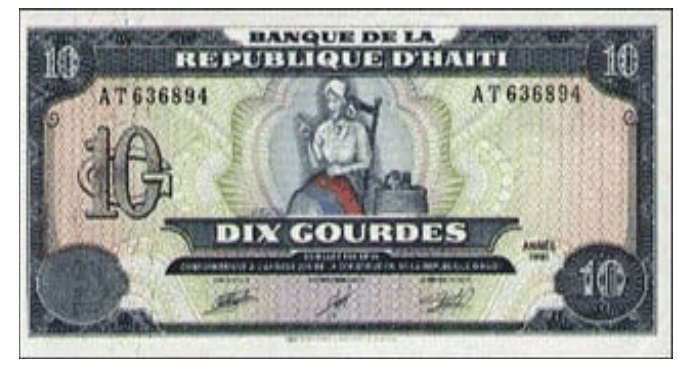

\footnotetext{
44 Toussaint Louverture's nephew. The Louverture Project; http://thelouvertureproject.org/index.php?title=Sanite_B\%C3\%A9lair

${ }^{45}$ Jomini, Antoine-Henri. (1842). Histoire critique et militaire des guerres de la Révolution. Brussels.

${ }^{46}$ Jomini, Antoine-Henri. (1842). Histoire critique et militaire des guerres de la Révolution. Brussels.
} 
of the Congress of Arcahaie. After Catherine Flon had sown the bicolore, the Generals of the Haitian Revolution at the Congress "solemnly swore an oath of fealty to Liberty or Death on this flag which was to lead the slaves to victory and freedom. ${ }^{47}$ This oath, which history has named the Oath of the Ancestors, is the equivalent of the one that the deputies of the Third Estate swore at Versailles June 20, 1789”48. (Haiti: A Slave Revolution p. 100) $)^{49}$.

Catherine Flon is widely regarded by Haitians as one of the heroes of the fight to end slavery.

\section{The Caribbean - Barbados}

\section{Nanny Grigg - 1816 Barbados Uprising}

When talking or

writing about the Barbados

Uprising (also known as the

Bussa Rebellion), more
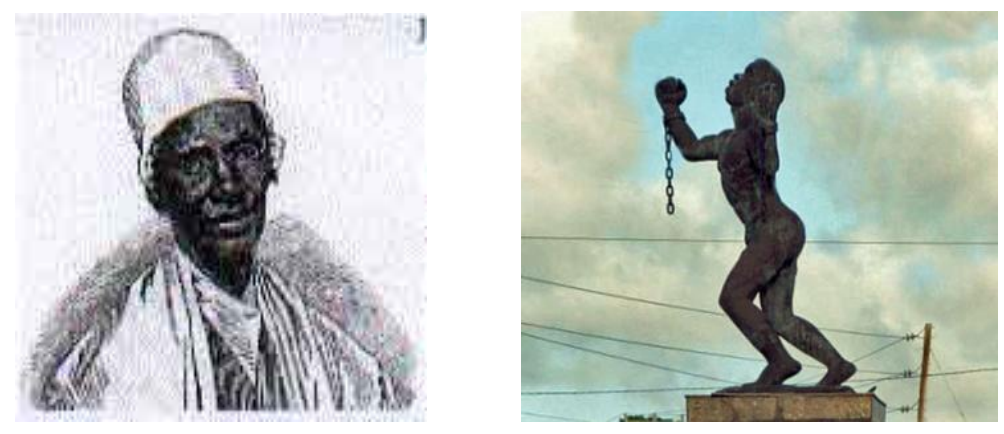

attention is paid to Bussa (also known as Busso or Bussoe), who was born a free man in Africa in the 18th century. He was then captured and brought to Barbados as a slave.

\footnotetext{
${ }^{47}$ Méléance, Emide. (2006) Catherine Flon and the Creation of the Haitian Flag, in Revolutionary Freedoms: A History of Survival, Strength. Coconut Creek, FL, Caribbean Studies Press, p. 91f.

${ }^{48}$ This event is often seen as the start of the French Revolution: The Tennis Court Oath; French: serment du jeu de paume. The Louverture Project; http://thelouvertureproject.org/index.php?title=Catherine_Flon

${ }^{49}$ Chin, Pat; Dunkel, Greg; Flounders, Sarah, and Ives, Kim, comp. and ed., Haiti: A Slave Revolution: 200 Years After 1804. New York: International Action Center, 2004. (Translation of an article in French by Fleurimond W. Kerns published in Haïti-Progrès. (May 18, 2003)).
} 
His existence is documented in historical records but there are no details about his lifewhether or not if he was married or even his exact age. What is known is that he was a head Ranger at Bayley's Plantation, and that he was also brave, strong and determined to enforce change. There is also little known about Nanny Grigg, other than she was valued at $£ 130$ (which at that time, was expensive for an enslaved person), and that she worked at the Simmon's plantation. Historical accounts indicate that she was a literate woman and knowledgeable about the Barbadian revolution, and that she was one of the senior ensl aved people who helped to plan the uprising. Nanny Grigg told her followers that the only way to obtain freedom was to fight for it. However, historical accounts do not say that she actually led the uprising. Instead, the records say that it is Bussa who led the rebellion on Sunday, April 14, 1816, against the British sugar cane planters.

According to historian, Hilary Beckles, "the rebellion represented an attempt by the slaves to assert some influence on the general abolitionist politics of the time. What distinguished this rebellion from many of the others was that it was not a spontaneous exercise, but rather a calculated blow for freedom, planned, organized and executed by elite slaves on several Barbadian estates.”

Most historians now say that Bussa was the principal conspirator and that other revolutionaries joined him, including Nanny Grigg. But that is as much credit as they give her for her role in the Barbados Uprising. However, Barbadian historian Trevor Marshall is making the case for another female to be a national hero of Barbados. 
Marshall who is the head of the history department at the Barbados Community College and part-time lecturer in Cultural Studies at the University of the West Indies Cave Hill, said that Nanny Grigg who was involved in the Bussa Rebellion in 1816 should also be a national hero. $^{50}$

Speaking as one of the panelists at the Celebration of Day of Women of the Americas 2009 under the theme “Care-Giving, Supporting, Developing and Leading: Women’s Contribution to Nation Building” at the Solidarity House of the Barbados Workers Union, Harmony Hall, St. Michael, Marshall said that despite the debate that historians have over whether the decision for the rebellion came from Bussa or Washington Franklyn, it was Nanny Grigg who originally planned the rebellion for December 1815. According to Marshall, because the timing was not right, it was Grigg who said that the rebellion must be in Easter the following year and so the rebellion started in April 1816.

"It came from the head and lips of Nanny Grigg and she has not been rewarded for her bravery,” Marshall said. And that the "greatest result of independence since 1962 in the region has been the liberation of black and Indian women in the Caribbean.»51

\footnotetext{
${ }^{50}$ Marshall, Trevor, Nanny Grigg Deserves National Hero Status, The Barbados Advocate Newspaper, February 20, 2009.

${ }^{51}$ Marshall, Trevor, Nanny Grigg Deserves National Hero Status, The Barbados Advocate Newspaper, February 20 , 2009.
} 


\section{The Caribbean - St. Thomas, U. S. Virgin Islands}

\section{Queen Coziah Harmon - 1872 Coal-Carriers Strike}

Queen Coziah Harmon, and her three sisters, Clara, Ezba and Lala, were all coal loaders on St. Thomas. For all intents and purposes, the coal-carrier strike on St. Thomas in 1872, embodied the principle of nonviolent protest, a concept that was to become a central ingredient of the civil rights movement of the 1960s under the inspired leadership of the Rev. Dr. Martin Luther King, Jr. (The Virgin Island Daily News, January 19, 2006).

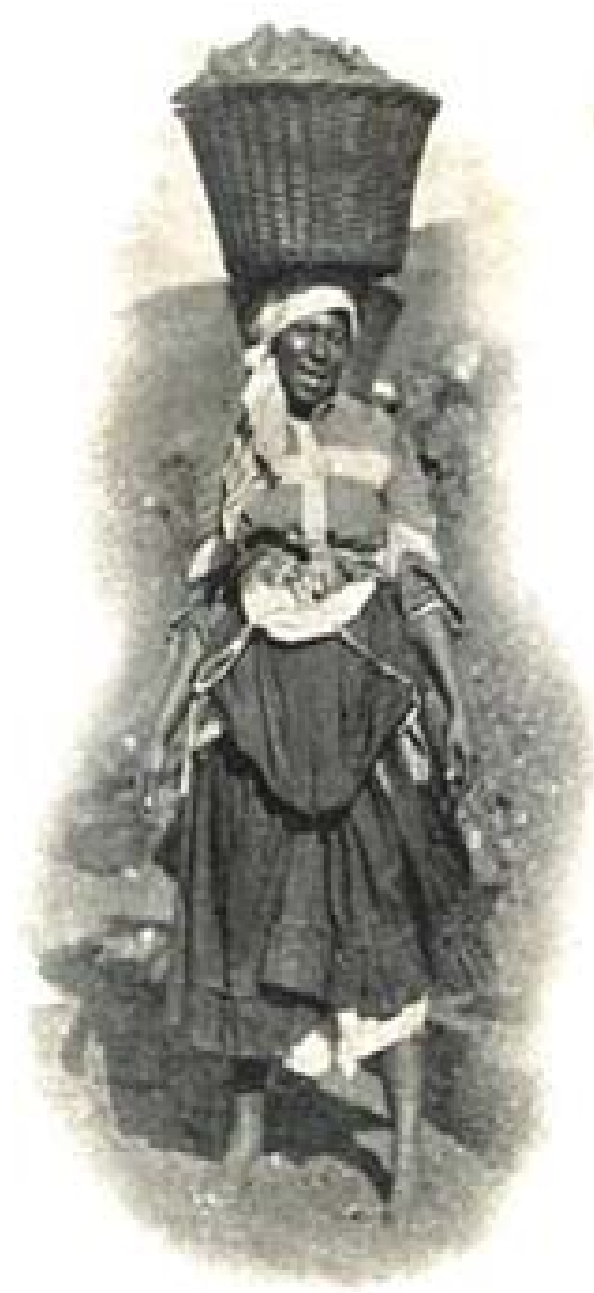




\section{The Living African-American History}

On July 27, 2006, I interviewed Ann Whiting, a direct descendant of Queen

Coziah Harmon, in

Las Vegas, Nevada.

Ann noted that at no

time did Queen

Coziah and her sisters

want the coal strike to

be of a violent nature.

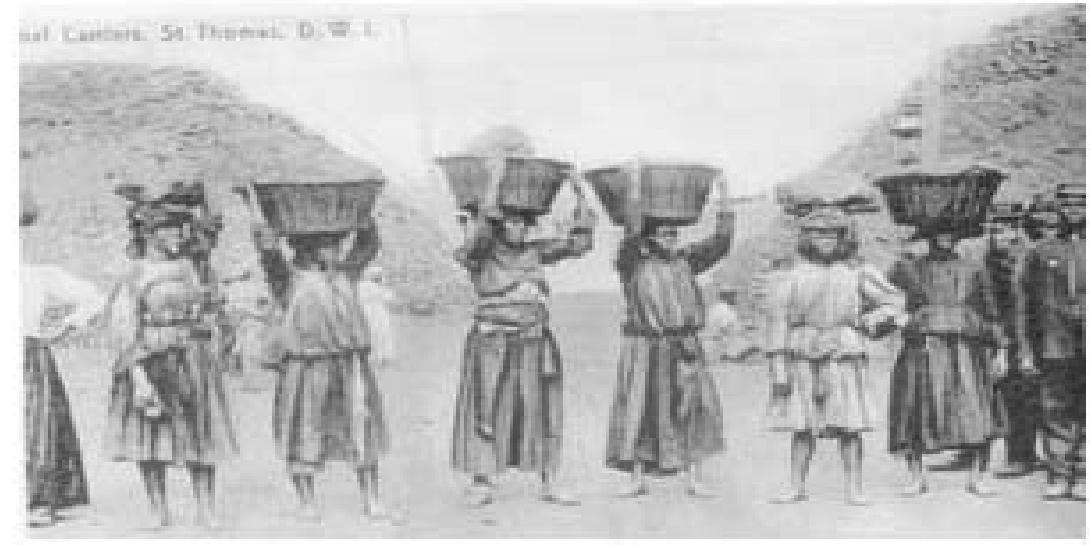

They were to accomplish the goals they set out by non-violent means only. She also

noted (as does Eddie Donoghue, who wrote the play, “Queen Coziah”), that it is considered ironic that whereas Martin Luther King, Jr. drew many of his followers from black colleges, Queen Coziah and the participants in the coal-carrier strike had little or no

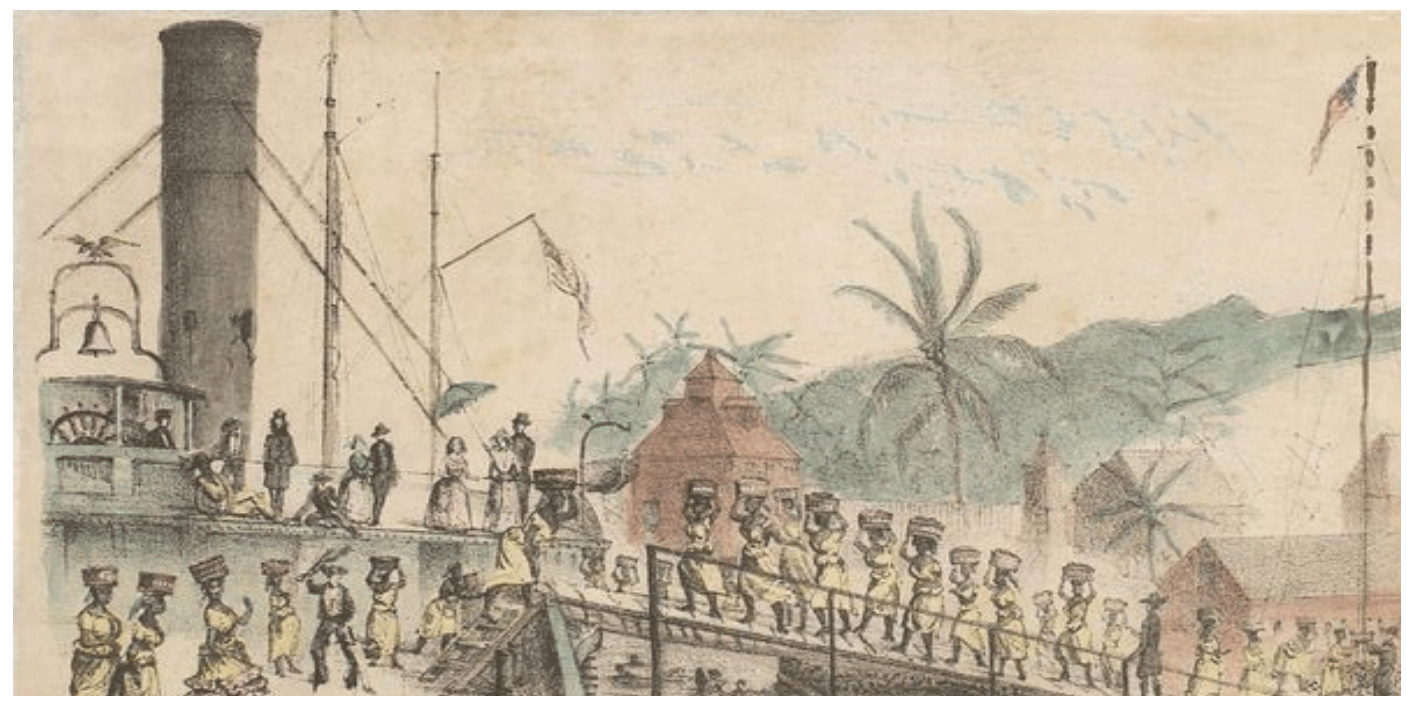


formal education. Yet both groups had a disciplined commitment to nonviolent action and nonviolent resistance.

Queen Coziah, was intuitively aware that given the size of the well-equipped Danish militia and fire corps arrayed against them, any collective violent action on the part of the strikers was doomed to culminate in bloodshed and a setback for their cause. Queen Coziah was non-compromising in her approach. As she addressed the coal strikers gathered in the park ready to march on the three major ship-coaling companies with offices on Main Street, she emphasized the need for nonviolence. Violence, she insisted, would tarnish the moral justification for the strike.

\section{The Caribbean - Tobago, West Indies}

\section{Ti Piggi/Ti Piggy - 1876 Belmanna Riots (Tobago) ${ }^{52}$}

Every year on the small island of Tobago --the sister island of Trinidad, people in the Roxborough village re-enact the Belmanna Riots. The re-enactment is part of The Tobago Heritage Festival which was first staged in 1987. It is now a major event on the national calendar, especially for the island of Tobago. The festival spans a two-week period from mid July to early August.

In the immediate post-Emancipation era, a group of freed slaves from Barbados came to Tobago, to settle and work on the Roxborough Estate. However, the entrenched system of plantocracy dictated that a rigid socioeconomic order be maintained, and the

\footnotetext{
${ }^{52}$ Ottley, Carlton Robert, Tall Tales of Trinidad and Tobago, Horsford Printerie Publishers ([Port-of-Spain, Trinidad]), 1972.
} 
laborers were subjected to similar conditions that existed prior to Emancipation. One of the female workers was a woman known only by the name of "Ti-Piggi” (Ti-Piggy), and was later identified as the leader of the Belmanna Riots. On January 7, 1876 the migrant workers on the Roxborough Estate demonstrated against the oppressive conditions imposed on them by the planters.

After emancipation, in 1838, Tobago’s economic difficulties continued and were attended by political and administrative troubles. Apathy set in among the members of the Legislative Council, and many of them increasingly absented themselves from meetings. As a result, on the insistence of the Crown, in 1874 the Assembly passed an act amending the constitution, by which the house abolished itself and set up a singlechambered government called the Elected Legislative Council. This body consisted of fourteen members, six nominated by the governor and eight elected by a very limited franchise of white colonists. The planters greeted the first meeting of the Council, on February 5, 1875, with protest, denouncing the new arrangement as a violation of their rights. ${ }^{53}$

The planters’ protests changed to fear when the Belmanna Riots broke out in the Windward district in May 1876. The rioters were associated with disgruntled Barbadian immigrants who worked on an estate in Roxborough. By the end of the disturbance one of the rioters, Mary Jane Thomas, had been fatally shot by police officers. Corporal Belmanna, who was a black man, was sent to arrest the “incendiaries”, had been killed 
and his body dismembered; the courthouse had been burned and workers from other

estates had joined the disturbance. The governor sent a warship from Grenada to restore order. $^{54}$

Below is a reproduction of the Proclamation issued by Lt. Gov. R.W. Harley found in the Tobago Gazette. Date: Friday, May 12, 1876:

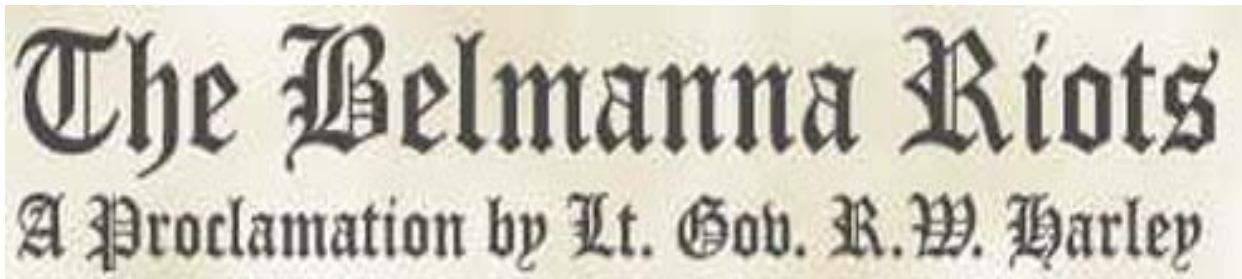

Whereas certain Acts of Incendiarism having taken place in the Windward District of this Island and great resistance having been offered to the arrest of the alleged incendiaries.......................... And whereas a certain police officer has been killed and others have been dangerously wounded in endeavouring to execute the Warrants for the arrest of the said incendiaries and whereas many persons in the said District have been guilty of serious breaches of the Peace and have used and are still using threats towards the property and persons of Her Majesty's well disposed subjects...................... I DO HEREBY DESIRE IT TO BE MADE KNOWN TO ALL - Persons who have been guilty of the said acts and also of any breach of the Peace will be speedily punished with the utmost severity of the law. ${ }^{55}$

\footnotetext{
${ }^{53}$ Luke, Learie B., Identity and Secession in the Caribbean: Tobago versus Trinidad, 1889-1980. Kingston: University of West Indies Press, 2007.

${ }^{54}$ Luke, Learie B., Identity and Secession in the Caribbean: Tobago versus Trinidad, 1889-1980. Kingston: University of West Indies Press, 2007

${ }^{55}$ Proclamation reproduced courtesy of La Magdalena by David Phillips - Available from Island Investments; 6399901.
} 
Forty persons were indicted for murder. Sixteen of them were sentenced to death, but their sentence was later commuted to penal servitude except, except for two who were later reprieved, since the planters acknowledged that slaves were expensive assets.

There is some debate among historians that the main body of the revolt was Barbadian immigrant laborers employed on Roxborough estate, while others claim the overseers were Barbadian and harsh disciplinarians. One thing that they all agree on for certain, is that the leader, a black woman known as "Ti Piggi” led the protest and was shot dead by Corporal Belmanna, which resulted in his own death by the protestors. ${ }^{56} \mathrm{I}$ am guessing that this is the same woman who was identified as Mary Jane Thomas, one of the rioters who had been fatally shot by police officers, thus resulting in the attack and eventual death of Corporal Belmanna.

The yearly re-enactment of the Belmanna Riot serves to remind the Tobagonians of the hardship that their African ancestors were forced to endure and ultimately to overcome, as well as the bravery of one female leader.

In 1878, two years after the Belmanna Riots, the Lieutenant Governor of Tobago, Augustus Frederick Gore, suggested uniting Tobago with Trinidad for the sake of economy; the Tobago government was having difficulties meeting its financial commitments. The Colonial Office did not accept Gore’s proposal immediately. However, Tobago's sugar cane-based plantation economy met its final demise in 1884

\footnotetext{
${ }^{56}$ Luke, Learie B., Identity and Secession in the Caribbean: Tobago versus Trinidad, 1889-1980. Kingston: University of West Indies Press, 2007.
} 
with the bankruptcy of the London finance house of A.M. Gillespie and Company. In 1889 Tobago’s political identity had to adjust to a new reality when the island was united with Trinidad to form the colony of Trinidad and Tobago. Under this union Tobago's separate political identity and its autonomy as a self-governing territory were significantly compromised. $^{57}$

\section{The Caribbean - St. Croix, U.S. Virgin Islands}

\section{Queen Mary Thomas - 1878 Fireburn Labor Revolt}

Just as the institution of slavery was replaced by the system of "peonage" after the Emancipation Proclamation freeing the slaves here in the U.S., a new tiered system of economic exploitation replaced an almost equal system of slavery, after emancipation, setting off a celebrated labor revolt on the island St. Croix, U.S. Virgin Islands.

After emancipation, another repressive system of exploitation was introduced which in essence matched the prior servitude of the slave economy. The former slaves were now paid for their work, but their salaries depended on an almost feudal subsistence of labor that bound them to the owners wherewithal in stipulated contracts. These contracts dictated the amount of time employed, the conditions of housing, and, effectively, the freedom of movement or advancement. ${ }^{58}$ The ordinance of 1849 under Governor-General Peter Hansen adjusted to a meager system of interdependence for the

\footnotetext{
${ }^{57}$ Brereton, Bridget. "Post-Emancipation Protest in the Caribbean: The 'Belmanna Riots' in Tobago, 1876." Caribbean Quarterly 30, no. 3 \& 4 (1984): 110-123.

${ }^{58}$ Dookhan, Isaac. A History of the Virgin Islands of the United States. 3rd ed. Kingston, Jamaica: Canoe Press, 1994.
} 
benefit of the planters, who supplied the very low wages and also adapted measures to bring in Indian indentured servants and immigrant laborers to make up for the worker shortfall. A small number of slaves responded by immigrating to St. Thomas to work in the more lucrative shipping docks, but as the number of passports issued was hindered by governmental interference, more and more "free" black workers simply adapted grudgingly to the existing system until the culminating events of $1878 .^{59}$

On October 1, 1878, a day before contracts were to be renewed, a crowd of black workers gathered in Frederiksted to desist the renewal of contracts, which were considered contractual forms of indentured servitude. Rumors began to be circulated that passports were unavailable and that a group of workers were being detained on route to Vieques. ${ }^{60}$

Violence soon ensued after another rumor broke out that a local drunk, Henry Trottman, who had been taken to the hospital by the police for a cut on his foot, was maltreated and died in police custody. This sent forth a barrage of stones from the crowd, and Danish soldiers responded by shooting back. As the soldiers barricaded themselves in the fort, the crowd began looting the surrounding area, setting fire to many buildings. The event is referred to as the "Fireburn" due to the rioters' employment of loose sticks and bundled torches to ignite the town buildings and later, the plantations.

\footnotetext{
59 Dookhan, Isaac. A History of the Virgin Islands of the United States. 3rd ed. Kingston, Jamaica: Canoe Press, 1994. ${ }^{60}$ Ibid.
} 
Military assistance from Lieutenant Ostermann came late to Frederiksted, and Governor Garde did not hear of the rebellion until October 2. As the streets were cleared by force from the town of Frederiksted, the rioters continued their ravage by attacking the numerous plantations, splitting into several groups and enticing a number of fellow onlookers to join in the destruction. French and British aide came to St. Croix, but Garde declined their assistance.

On October 5, Garde demanded that all workers return to the plantations. If they were not to return, they were presumed rebels. This effort, though, produced minimal results and further acts of rebellion continued. It is important to note, as Virgin Islands historian Isaac Dookhan says, that there was never any clear organization of the rebellion from the beginning. Nonetheless, leaders and heroes sprung from the disorder, such as “Queen Mary” or Mary Thomas, Axelline Salomon, and John Lewis. Over 60 black workers died as a result of the riot; only three whites were killed. The leadership of the parties was later attributed to recent immigrants of other West Indian islands, including Jamaica and Barbados.

Soon after labor reforms were put in order, such as the reform of October 24, 1879, which supposedly put in place a wage increase and liberalization of income for wage earners. The ordinance, however, did not improve much from the previous one issued in 1849. As Peter Jensen writes in From Serfdom to Fireburn and Strike: The History of Black Labor in the Danish West Indies 1848-1917, "The liberalization of labor conditions in the 1879, then, did not necessarily result in any improvements in the 
laborers' conditions, on balance, since it was obtained on the planters' and not the laborers' terms.” (Jensen 139). ${ }^{61}$

There is some

evidence which supports the idea that revolt was planned, for example, such

circumstances as the calm on Contract Day, which was usually a rowdy, rumdrinking holiday. It was so

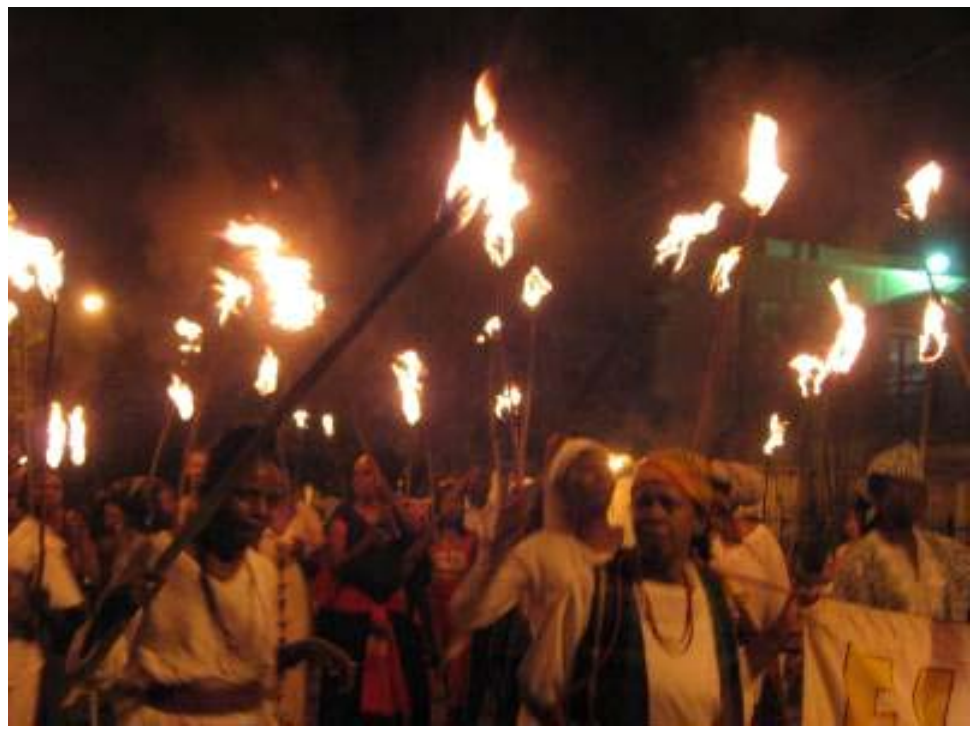
quiet, in fact, that Police Master Peterson in Frederiksted was moved to investigate the situation. Other evidence was that workers had failed to cultivate their provisional grounds during several weeks prior to the Fireburn. Gerard Emanuel, a student of the Fireburn who has collected data in the Danish National Archives, said, "some workers interrogated after the Firebu.rn say it was planned." The Reverend Dubois, the British Vice Counsel during the Fireburn, declared that he "knew of unrest but the worse they would have expected was some verbal protest, some type of work stoppage." Mr. Farrelly, a British planter whose property was destroyed, reported, "We had suspected a strike might take place, but nothing worse.”

\footnotetext{
${ }^{61}$ Jensen, Peter. From Serfdom to Fireburn and Strike : the History of Black Labor in the Danish West Indies, 18481916. Christiansted, St. Croix [V.I.]: Antilles Press, 1998.
} 
After more research, we now know that there were four Queens of the Fire Burn. The title of queen was bestowed on these women because they were selected by the workers on the plantations to preside over all ceremonies, rituals and celebrations. These women were held in the highest esteem and were well respected as leaders by their fellow workers. Fourteen other laborers were hanged for the action. Queen Mary was the lead Queen. There was also Queen Agnes and Queen Matilda and Bottom Belly. As it was illegal to hang women, the Queens were incarcerated in Denmark and after many years were released back to St. Croix where they lived out the rest of their lives.

\section{The Caribbean - Trinidad and Tobago, West Indies}

\section{EIma Francois (1897-1944) - Founder, NWCSA (Professor Rhoda Reddock Interview)}

Elma was born in St. Vincent in 1897. Life was gloomy: her father, a laborer, died when she was still little, the family lost all their belongings in the volcanic eruption that devastated the island in 1902, and there weren't any prospects for young women other than other than working as a domestic servant, picking cotton or finding some sort of employment in the sugar factory at

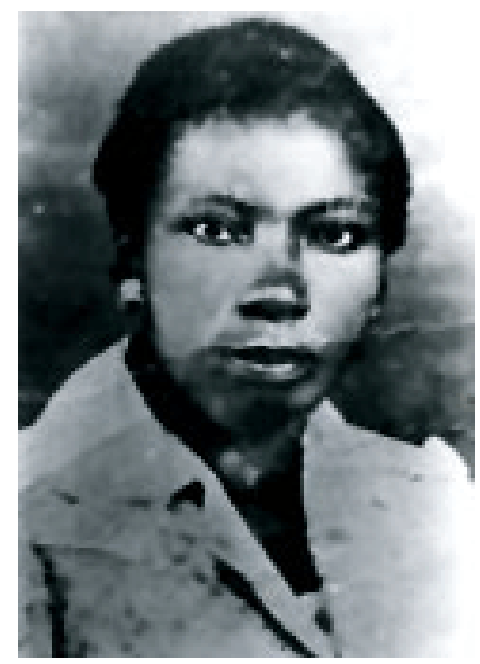
Mount Bentick. ${ }^{62}$

\footnotetext{
${ }^{62}$ Historical Biographies, Elma Francois, (c) Paria Publishing Co. Ltd. 2000; Newsday’s Millennium Special, January 1, 2000, Pages 34-35.
} 
Elma did the latter, and promptly got herself fired. Already socially minded as a young teenager, she tried to organise the workers in the sugar factory, which was not met with understanding by the owners of Mount Bentick. Elma moved to Kingstown, where she had a liaison with Albert James. This produced a son. James went off to fight in World War I, and after the war settled in Trinidad. In 1919, Elma as well migrated to Trinidad, leaving her two-year-old boy behind in St. Vincent. ${ }^{63}$

In her role as a political partner and ally, we can see that Elma Francois showed a personal concern for the development and the security of those in whose company she struggled. Her comrades 'looked up' to her for leadership. The organization required that men and women co-operate in developing their collective political consciousness instituting a dynamic relationship between the sexes. One cannot but help suggest again that the many sided relations in the social organization of labor which are the lot of Caribbean women - strong arm defender of the rest, reproducer of labor power, comforter, culturiser, and producer - strengthened Elma Francois and the other women activists in the NWCSA . Elma did not hold back from working with others even though there were some differences between them. She could see the larger oppression on which they were agreed and did not make the smaller conflict become an obstacle in the fight for the people to advance. ${ }^{64}$

\footnotetext{
${ }^{63}$ Historical Biographies, Elma Francois, (C Paria Publishing Co. Ltd. 2000; Newsday’s Millennium Special, January 1, 2000, Pages 34-35.

${ }^{64}$ Reddock, Rhoda, Elma Francois, The NWSCA and the Workers' Struggle in the Caribbean (London: New Beacon Books, 1988.
} 
"Outside of these realities, Elma Francois is a heroine because she personified timeless truths that many women nowadays should practice: political will."65 Elma Francois was also the first woman in the history of Trinidad and Tobago to be tried for sedition.

\section{The Caribbean - Trinidad and Tobago}

Gene Miles - Gas Station Racket (Father Anthony de Verteuil Interview)

Gene (Jean) Miles (1930-1972) is a name that has become synonymous with opposition to corruption, and her early death has given her the aura of a martyr, although I found during my interview with several individuals in Trinidad and Tobago, the title of martyr is highly debatable.

I first encountered Gene Miles on September 27, 2007 while browsing in the bookstore at the University of the West Indies (UWI) campus. Unable to enter the main library on campus, I decided to see what books were available that might help me get a better understanding of the culture and traditions of the Caribbean; in particular, Trinidad and Tobago.

\footnotetext{
${ }^{65}$ Historical Biographies, Elma Francois, (C) Paria Publishing Co. Ltd. 2000; Newsday’s Millennium Special, January 1, 2000, Pages 34, 35
} 
Atop one of the book stands was a book titled To Find Freedom: Historical Sketches of Trinidad by Anthony de Verteuil. I picked up the book and as I began thumbing through the pages, my finger stopped on page 109, and the following phrase from the fourth and fifth paragraphs caught my eye:

"Thirdly, many of the possible witnesses were reluctant to come forward through fear of victimization. Indeed, if it had not been for the exemplary cooperation of one in particular, the Commission's work would have been reduced to an exercise in futility. The one who made a difference was Gene Miles.”

Herein these two paragraphs I was introduced to an extraordinarily brave woman, who had died of a broken heart on Friday, December 8, 1971, shortly before midnight after she went to bed and after speaking to her mother.

\section{Gene Miles - Case Notes}

One of the first major cases of allegations of corruption in the post independence era in Trinidad and Tobago came to be known as the Gas Station Racket IEnquiry $(1965){ }^{66}$

Evidence given by Gene Miles, a civil servant in the 1960s, implicated the Ministry of Petroleum, Mines, Industry and Commerce in wrong doing in regard to the allocation of gasoline stations to businessmen who were leasing them from the Government. She caused a sensation by alleging corrupt practices by several highranking figures. $^{67}$

\footnotetext{
${ }^{66}$ Trinidad Guardian, “Millions of Dollars in Gas Deals, Alleges Miss Miles.” 22 Jul. 1966: 1. ${ }^{67}$ Ibid.
} 
Raffique Shah tells the story in another way in his article, “Jean Miles: Hero of

\section{Trinidad and Tobago against Corruption”:}

The 'Lockjoint scandal', as I recall it, Lockjoint was a foreign firm that was contracted to upgrade the sewer system in Port of Spain. It was alleged that ministers in Williams's government took bribes from the company. Hard on the heels of that mess came the 'gas stations racket', which brought to the fore an unsung heroine of this country, Jean Miles.

At the time, the establishment of gas stations was strictly controlled by the central government. Anyone wanting to get into the lucrative business needed government's permission. Miles, a glamourous civil servant (as they were called back then), stepped out of her high-caste crease to cause a furore by publicly accusing high PNM officials of being corrupt. There was an inquiry into the allegations, at which she gave damning evidence.

From that moment, not even her relationship with the notorious John O'Halloran could save her from the might of the PNM. Miles died in the 1970s, a virtual vagrant, pauperised and made an outcast by the same Williams who had attacked corruption with full force-before he came to power! ${ }^{68}$

During my interview with

Father Anthony de Verteuil, he

revealed that he knew Gene’s family

very well, and confirmed what I'd read

in his book, To Find Freedom:

Historical Sketches of Trinidad as well as all of the newspaper articles from

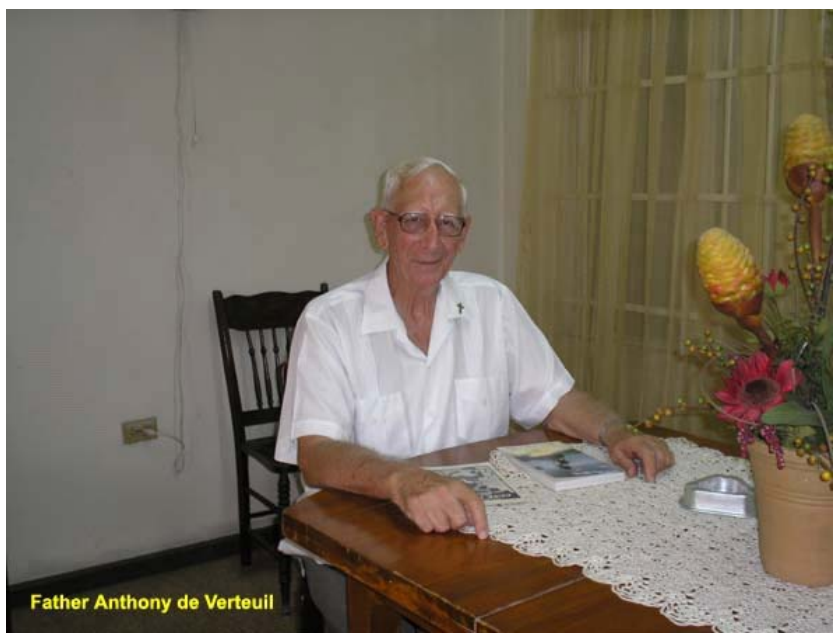

the Trinidad Guardian and Daily Express during this period of time.

\footnotetext{
${ }^{68}$ Shah, Raffique, A Culture Of Corruption, “Jean Miles Hero of Trinidad and Tobago Against Corruption”, July 22, 2001. http://www.trinicenter.com/Raffique/2001/Jul/222001.htm
} 


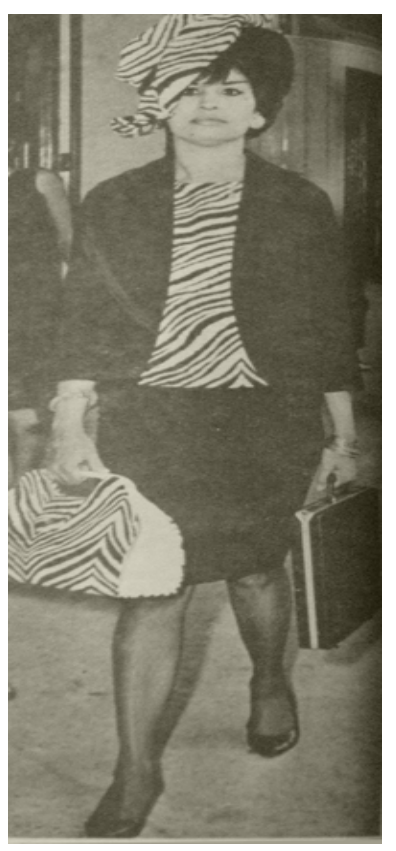

According to evidence in the inquiry, it is alleged that the government ministry in which Gene Miles worked responded to her testimony with victimization. She was dismissed from the civil service and fought tenaciously for “rights”, having on one occasion been ordered out of the gallery of parliament for interrupting statements made about her. It is said that Gene Miles was persecuted and hounded afterwards by the powers that be and others, which led to her suffering a nervous breakdown. She became a legend in her own time not solely because of the inquiry, which made her well-known, but because of her colorful and flamboyant character. ${ }^{69}$ This article from a January 14, 2000 issue of the Independent sums it up pretty well:

Public servant and popular model Gene Miles took on the powerful PNM administration in an anti-corruption campaign in the 1960s and paid the ultimate price. She caused a commission of inquiry to be launched into what became known as the "Gas Station racket". But along the way Miles, who was rumoured as having an affair with PNM minister John O'Halloran, lost her job, became a nervous wreck and in the end died a virtual vagrant. ${ }^{70}$

She seemed to be full of compassion for the underdog, often taking up causes based on principle and putting herself in the forefront of protest. She always identified strongly with black people. During carnival 1966, which by its demonstrations in favor

\footnotetext{
${ }^{69}$ Trinidad Guardian, “Model: Tam Sold 'Secrets,” 23 Jul. 1966: 1.

${ }^{70}$ Independent, Women of the Century, Page 18, January 14, 2000.
} 
of "blackness", forecast the black power uprising of 1970, Jean Miles was seen leading a “protest” Jour O’uvert band called Jour O’uvert by Night.

For the Carnival of 1970 she showed her commitment to the masses by singing calypso that season in a calypso tent. Despite her cheerful nature and the side of her character that some called "exhibitionist", it was clear that the social pressures were taking a toll on her. She spent some time at the St. Ann's Mental Hospital For the Carnival of 1970 she showed her commitment to the masses by singing calypso that season in a calypso tent. Despite her cheerful nature and the side of her character that some called "exhibitionist", it was clear that the social pressures were taking a toll on her. She spent some time at the St. Ann's Mental Hospital and she is reputed to have become an alcoholic. Gene Miles eventually died from a heart attack on December 9, 1972 at her home in Woodbrook, Port-of-Spain. I surmised that she simply died of a broken heart!

Although I and many others look at Gene Miles as a true hero who did her part in bringing to light the corruptive practices with an elite government office which she was part of, there are others who opposed the name Gene Miles as a hero of Trinidad and Tobago. Yet, the NAR (National Alliance for Reconstruction) in 1990 sought to bring some positive recognition to what Gene Miles did by having a monument erected in her honor, and to rewrite her history in a definitive way; a memorial that would forever celebrate her as a Corruption Fighter and forever condemn the PNM (People National Movement) as her persecutor. Those opposed her recognition then as do now only looked at Gene Miles as nothing more than a "mad (insane) woman". The following parts 
of an article by Lennox Grant, titled "Who Remembers Gene Miles? Not NAR" from the

July 24, 2005 edition of the Trinidad Guardian, gives us a little more insight of the

outrage of some who terrorized the NAR after learning that they wanted to retrieve her

reputation: ${ }^{71}$

Hardly anyone these days, including voters in San Francique, pays attention to the National Alliance for Reconstruction, whose politics consists of a staunch refusal to give up the ghost. Indeed, it's a politics based on ghosts and crumbled glories. Amid haunting memories of the once-mighty fortress of NAR power, shadowy figures derive a single energizer from a favorable present moment. For it's become fashionable to contemplate, if not to revisit, a local experience of terrorism. NAR retainers sense an opening for a claw-back of lost opportunity to complete unfinished business from July 27, $1990 .^{72}$

Last Monday, the NAR candidate won 57 of the 4,704 votes cast in San Francique. With no electoral laurels on which to rest, Wendell Eversley, the NAR's secretary of field operations, has been sitting, in the politically correct lotus position for a hunger strike, on blankets under a shed opposite Whitehall. He was sitting in the Parliamentary public gallery on that evening just under 15 years ago, when fighters burst into chamber shooting and shouting the greatness of Allah.

"I could have been a dead man today," Mr. Eversley muses. After five hours, the Muslimeen, having weighed his worth as a hostage, let him go. Mr. Eversley is now giving up food to press the government for an enquiry into what the hell all that was about.

If he doesn't know it, July 27, 1990 remains a living parable that counsels against pushing the PNM too hard, even when that party is in opposition.

Now that it's in government, the teaching of that parable tends to be forgotten. As a result of contemporary opposition hard-pushing against the PNM:

1). One commission is investigating the links of a Cabinet minister to questionable movements of construction materials.

2). Another commission is checking out allegations of bribe-taking against another Cabinet Minister, and also against the PNM (People National Movement) party chairman.

\footnotetext{
${ }^{71}$ Grant, Lennox, Who remembers Gene Miles? Not NAR, Trinidad Guardian, July 24, 2005, Trinidad Publishing Company Limited, (C)2004-2005.

${ }^{72}$ Ibid.
} 
3). Reports surface about six-figure legal briefs for government projects enjoyed by the deputy Speaker.

4). Media outlets owned by a high-profile PNM supporter gain more than one third of the advertising and public relations business of the Ministry of

Community Development, Culture and Gender Affairs.

5). In the same ministry, revenue records in the custody of audit staff

"disappeared from the cabinet where they were stored overnight."

The article goes on to talk about how in July 1990, the NAR (National Alliance

for Reconstruction) stage managers were playing to the gallery of people like Mr.

Eversley. The script called for turning the screws on a then helpless PNM, and that

foreign courts, in judgments covering its ruling-party years, had found the PNM to have

been aiding and abetting corrupt dealings, even trying to cover up. Having finally nailed

down this finding, the NAR regime, led by ANR Robinson, sought actually to crucify the

PNM.

This is where Gene Miles, once a political patron saint of anti-PNM corruption faith, fleetingly re-entered history. She had by then been dead nearly 18 years, buried in an unmarked grave. Footnotes to PNM-inspired history had questioned her sanity, her sobriety and the purity of the motives that led her to denounce large corruption occurring on the PNM watch. ${ }^{73}$

The NAR, which is keen today about proper recall of the 1990 history, never troubled in its own time in office to recount the historical record on which it proposed to eulogize Ms Miles. Not the least historical monograph of her period was ever commissioned. It was sufficient to invoke her folk memory in the manner of raising a banner bearing an anti-PNM inscription.

Today, more than three decades after her death, the Gene Miles period remains hardly remembered, and her importance as a corruption whistle-blower not recognised at all. She had emerged before her time; a mouthy red woman, ready to make a spectacle of herself as a champion of causes. She became a freelance, all-purpose dissident, who wrapped herself in the national colours to march at the head of sundry radical nationalist or patriotic demonstrations.

But those were times past her heyday. Her big moment was as star witness in the 1966 Karl de la Bastide inquiry into the gas station racket in which scads of dirty

\footnotetext{
${ }^{73}$ Grant, Lennox, Who remembers Gene Miles? Not NAR, Trinidad Guardian, July 24, 2005, Trinidad Publishing Company Limited, (C)2004-2005.
} 
dollars had changed hands in bribes, kickbacks and fix-ups between 1961 and 1965.

In public hearings, the flamboyant Gene Miles told what she knew from her vantage point as a civil servant in the Factory Inspectorate, which was the final authority for granting gas station licences.

Ms Miles made headlines, but many more enemies from PNM and PNMprotected circles. She eventually went down in flames; was fired from her job; and fatally targeted in a mauvaise-langue campaign that portrayed her as a mad woman, in the least of the epithets. The luckless heroine of the gas station racket-busting died in near-disgrace in 1972.

But the commission, before which she testified over seven days of public hearings, confirmed the massive corruption she had charged. The Eric Williams government took two years to table the report in Parliament, and ignored the recommendation to move against the Senior Factory Inspector "without delay". That officer retired with benefits; Gene Miles lost her job and, many concluded, her mind. Her legacy survives today as a lesson teaching the profitlessness of pursuing PNM corruption.

Grant finishes the article by saying that after the Muslims attacked fifteen years

ago, the NAR, at once dropped

both the Gene Miles memorial

idea and the PNM corruption

crusade. $^{74}$ And to my knowledge,

there haven’t been any other

attempts to bring recognition to

Gene Miles in the way of a

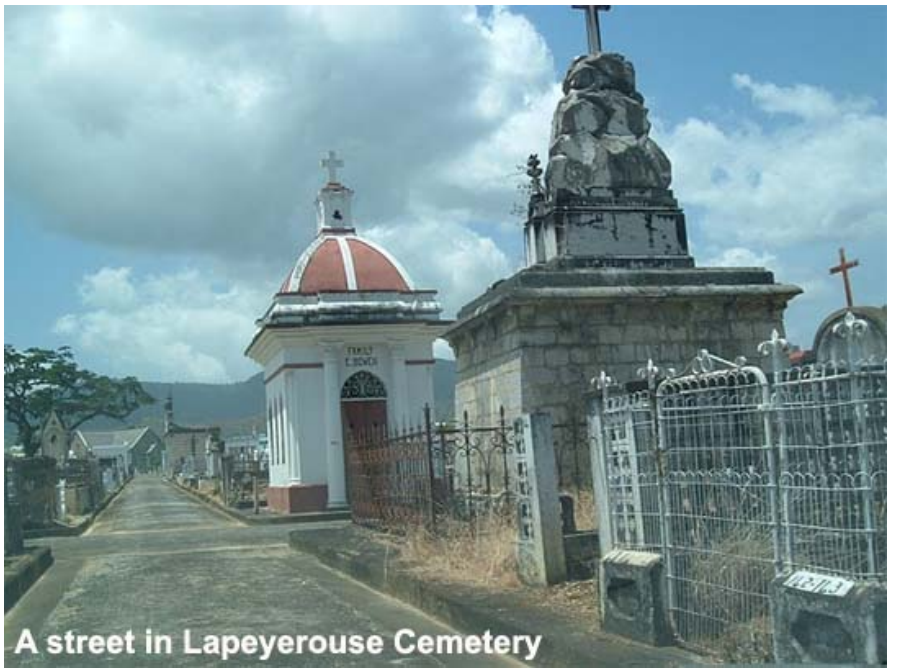

memorial, for the brave role she played in bringing down the gas station corruption in

Trinidad and Tobago.

\footnotetext{
${ }^{74}$ Grant, Lennox, Who remembers Gene Miles? Not NAR, Trinidad Guardian, July 24, 2005, Trinidad Publishing
} 
Last, I would like to say

that when interviewing

individuals in Trinidad and

Tobago during my Fulbright

grant period in 2008, I found that

when the question, "What about

Gene Miles”? was asked, one of

two responses was received: 1 ).

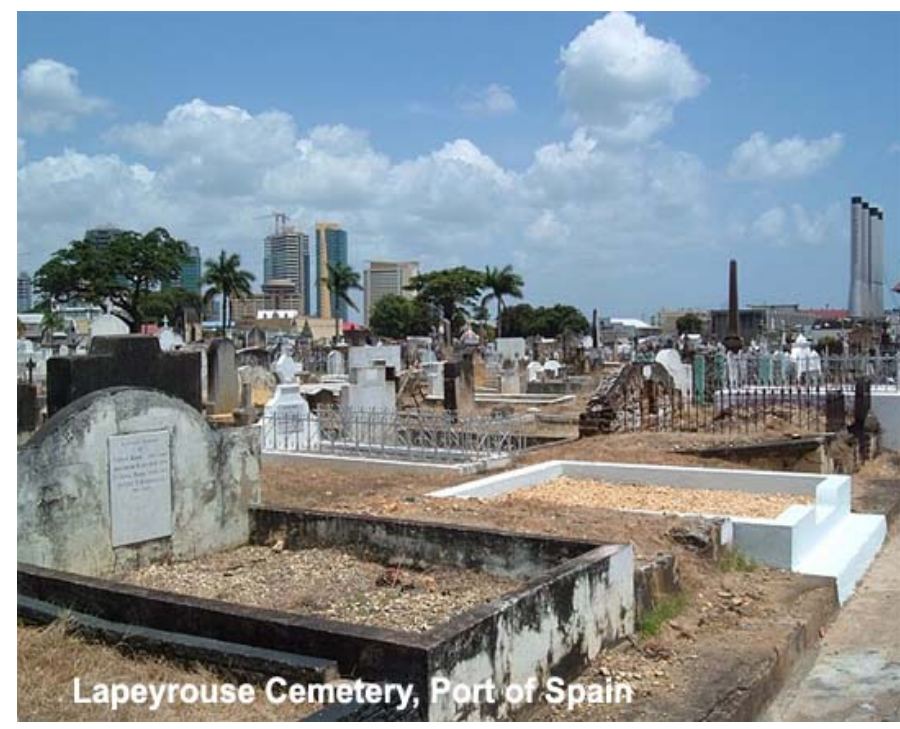

She was a very brave, courageous woman or 2). She was really a slut who was sleeping around with the guys at the top and ended up being nothing.

Two days before leaving Trinidad and Tobago, I was able to visit Lapeyrouse Cemetery in Port of Spain with directions from Father Anthony. The visit to the cemetery was a most extraordinary experience with an aura unlike any other cemetery

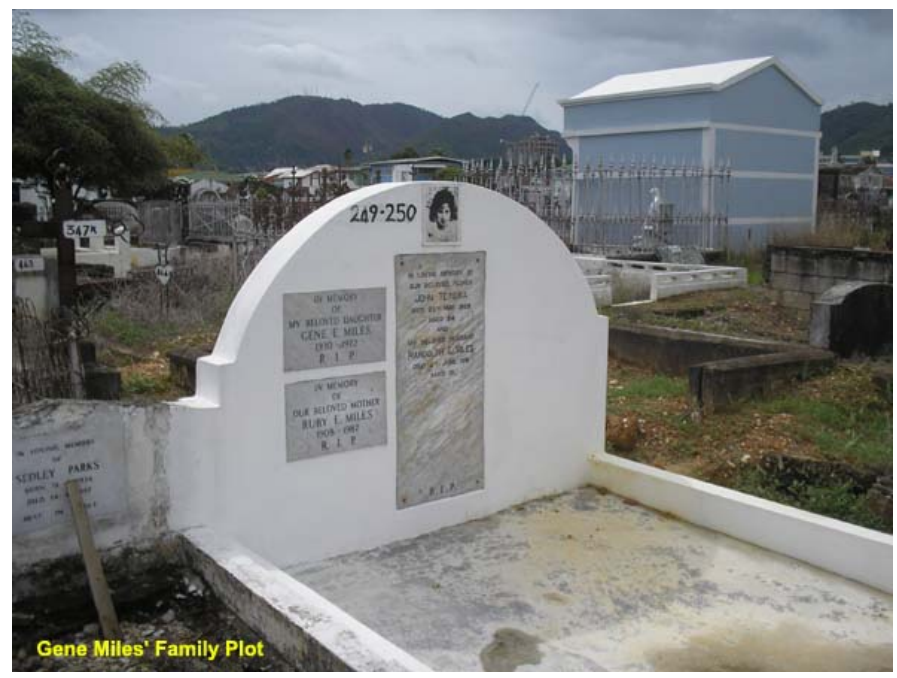

I've ever visited. Entry to the is quite different and even a little bit overwhelming. The main entrance arch bears the date 1869 , which is what I surmised, was the age of the cemetery. But upon further research and

Company Limited, (C2004-2005. 
speaking with some of the clerks in the National Archives, I found that the age of Lapeyrouse was a much earlier date (officially 1813, but even earlier).

It took me awhile to find

Gene Miles' grave. In fact, I

was nearly ready to drive out of

the cemetery, when a face

caught my eye. It was Gene

Miles! Well, it was a

photograph on her tombstone. I

immediately grabbed my digital

camera, got out of the car and

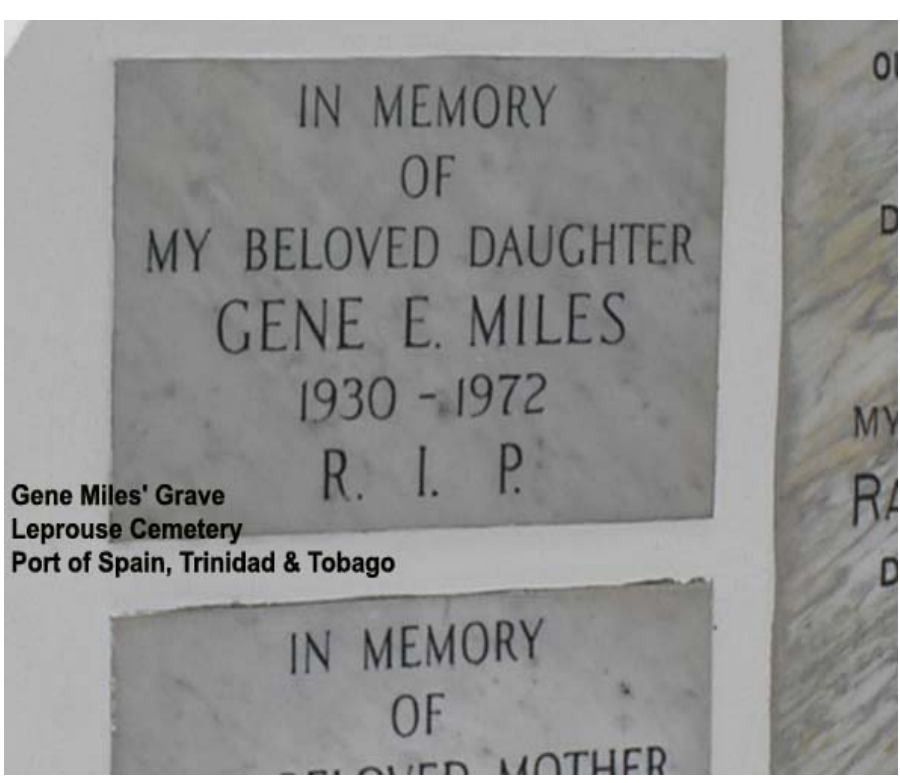

began snapping photos of her gravestone. It was as if she had wanted me to find her grave, just when I was about to give up and leave the cemetery.

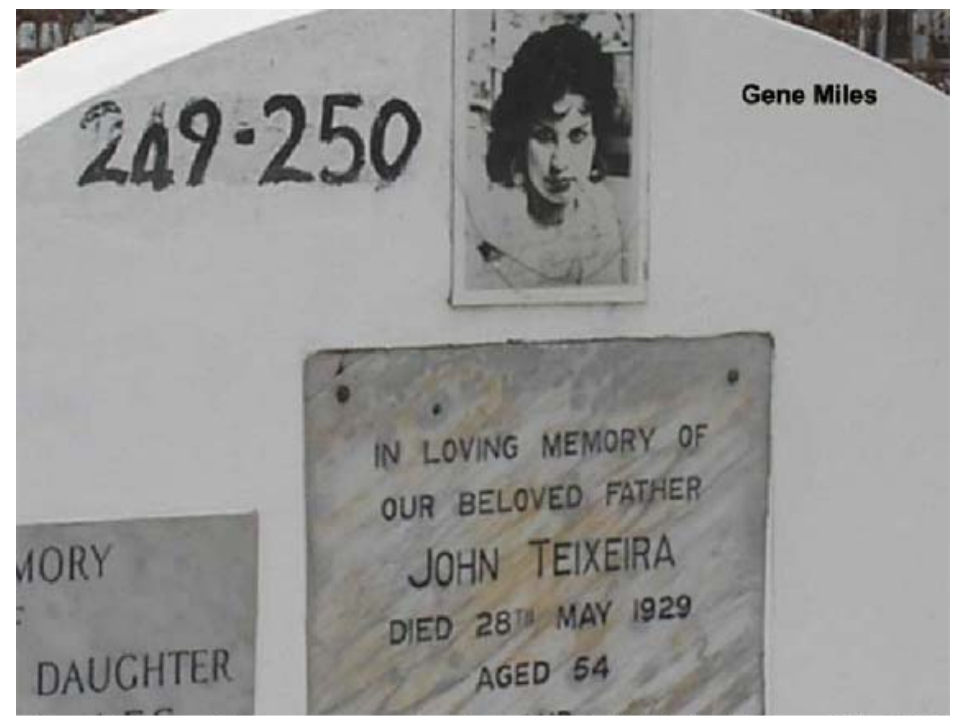

Gene Miles' grave; Lapeyrouse cemetery; Port of Spain, Trinidad and Tobago (July 2008)

Photo courtesy author's collection 


\section{Faded but Not Forgotten}

(for Gene Miles)

Quietly you slipped away

On that somber December day

You did your part for the small of us

Fighting for some needed justice.

Who knew the hearts you'd touch

And the corrupt would hate you so much

I hail you for standing strong

For helping to right so much wrong.

A Child of Mary, with the cherry smile We held the light that was ours for awhile

You, the lover of flowers - a flower yourself

A fine piece of china not left on the shelf.

Some say the crush on him was your downfall Closing your eyes to his wrong, wasn't good at all You recognized God's calling, heeded his voice Little did you realize the results of your choice.

Beat, broken and betrayed, you carried your cross The power of "Mauvais Langue" was not at all lost It found you at many unprepared moments Mauvais Langue, and all its torments.

Making front-page news everyday

The abusive phone calls wouldn't go away

Determined you were, going head strong

Knowing your effort would help right some wrongs.

A kind and brave woman some called you

An alcoholic, a lunatic, others say is true

Some just out to get you, no matter what

Others see the lessons your bravery taught.

You never spoke out against the condemners

"Leave it to God" was what you remembered

"I'm going to die before Christmas", you proclaimed

Even after doing good, nothing was the same.

A heart attack the doctor said

But more like a broken heart instead

At Lapeyrouse your struggled ended

The birds watched, the doves descended.

The flower faded from within our midst

The sun and dew finally met and kissed.

Clare J. Washington, (C10/02/09 


\section{The Caribbean - Grenada}

\section{Jacqueline Creft (1946-1983) - 1979 Grenada Revolution}

Jacqueline Creft was one of the early leaders of the

New Jewel Movement. She was a secondary school teacher and, like George Louison, was one of those who believed in mass education, mass participation, and mass mobilization. ${ }^{75}$ In January 1973 at La Sagesse in St.

David's, she stood with Maurice Bishop and Unison

Whiteman in front of the large gathering protesting the locked gates to the beach at Lord Bronlow's estate. While in Trinidad \& Tobago from 1976-1977, she was regional

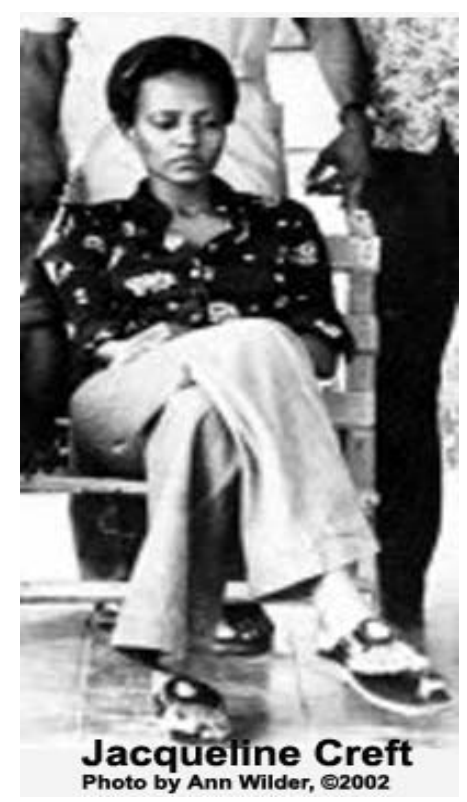
coordinator for youth affairs, with the Christian Action of Development in the Eastern Caribbean (CADEC), an arm of the Caribbean Council of Churches (CCC). Eventually the Eric Williams government in Trinidad banned her [and journalist Rickey Singh]. She returned to Grenada in 1977 after her Trinidad work permit was revoked. She said, according to the Free West Indian:

"Gairy refused to give me work, and as I was a new mother, I had another life to think about," she said.

\footnotetext{
${ }^{75}$ Wilder, Ann Elizabeth, 2001-2008, The Grenada Revolution Online, http://www.thegrenadarevolutiononline.com/sitemap.html
} 
With her additional responsibilities, she sought an employment position in Barbados with Women in Development. Creft was back in Grenada during the takeover March 13, $1979 .^{76}$

By January 1980, Jacqueline Creft was serving as Minister of Education in the People's Revolutionary Government. She coordinated the Voluntary School Repair program. As Minister of Education in 1981, she was in charge of Cuban scholarships. Speeches by the People's Revolutionary Government at the First International

Conference in Solidarity with Grenada, November 1981, included "The Building of Mass

Education in Free Grenada" by Cde. Jacqueline Creft, Minister of Education, 4

November 1981. Her speech recounted in part: ${ }^{77}$

"Comrades, ever since our party was founded in March 1973, high upon our list of priorities has been the transformation of this twisted education system that we inherited from colonialism and from Gairy. We were determined to change a system which so powerfully excluded the interests of the mass of our people, and which also wove webs of fear, alienation and irrelevance around our children's minds . . . whether it was Little Miss Muffet, the Cow That Jumped Over the Moon, William the Conqueror, Wordsworth's Daffodils, or the so-called 'Discoveries' By Christopher Columbus of the 'New World'. The lucky few of us who went to secondary school, learned about Cromwell's Revolt but not about that of Fedon. We learned about the reforms of Wilberforce yet nothing of Marryshow. They made us read Shakespeare and Jane Austen, but kept silence about George Lamming. Right from the beginning of our struggle we called for an education system which not only services all our people, secondary schools which would freely open the doors to all our people without the constraint of fees, but also a curriculum which would eliminate absurdity from our classrooms and focus our children's minds upon their own island, their own wealth, soil and crops, their own solution to the problems that surround them. For too long we had been brainwashed to think that only Europe and America held the answer.”

\footnotetext{
${ }^{76}$ Wilder, Ann Elizabeth, 2001-2008, The Grenada Revolution Online, ${ }^{77}$ Ibid. http://www.thegrenadarevolutiononline.com/sitemap.html
} 
Creft helped establish and led the Ministry of Women's Affairs in June of 1982 with its inauguration in August. The Secretary (Junior Minister) at that ministry was Phyllis Coard. Creft quit the party activities [the New Jewel Movement] in November 1982 after having been active within it since its early days. In March of 1983, Creft was demoted within the government from Candidate to Applicant member "although the reasons are unclear," according to Pryor.

In the tense days of early October 1983, Creft met privately with Bishop and was one of the few who visited with him. When Bishop was placed under house arrest on 12 October 1983 in his Mt. Wheldale home, Jackie came to visit the very next day. She was told by security if she saw him, she would also be detained. She agreed.

GBSS (Grenada Boys' Secondary School) student Thomas Cadore led a group, around noon on 19 October 1983, around left to the back of Bishop's Mt. Wheldale home to free Bishop and Creft. Bishop and Creft were taken to Fort Rupert with others, switching vehicles.

On the way down Lucas Street, the procession passed by the home of Jackie's mother, Lynne. Mrs. A.J. Creft and her daughter kissed and exchanged words, but never saw each other again, according to one report. While the procession moved on Lynne Creft was gathering food, which she was able to bring to the Fort before the shooting began. Around 2 p.m., Bishop, Creft and seven others were executed at Fort Rupert. Jacqueline Creft, from reports, was supposedly pregnant with Maurice Bishop's child 
when executed that tragic day, October 19, 1983. The information about Jackie's pregnancy has, so far, been hearsay.

Maurice Bishop and Jacqueline Creft were parents of a child in the 1970s. The paternity of Bishop and Creft's son, Vladimir, was legally established in April 1978. Vladimir, born December 4, 1977, died a violent death in Canada in 1994. At Wilberforce Cemetery a bust of Maurice Bishop stands near a tombstone for Vladimir whose death date reads 1995.

\section{The Caribbean - Trinidad and Tobago}

\section{Rhoda Reddock - CAFRA}

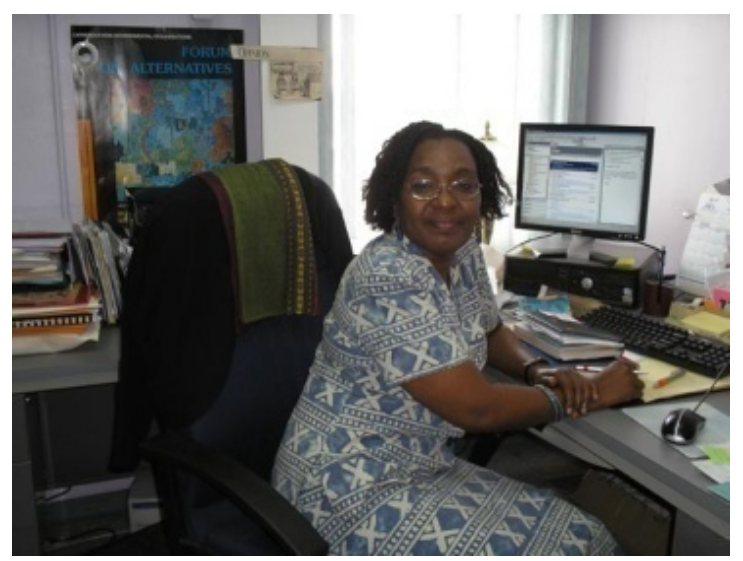

Dr. Rhoda Reddock is full professor and head of the Centre for Gender and Development Studies at the University of the West Indies, St. Augustine campus in Trinidad and Tobago, West Indies. She is an activist in the Caribbean Women's

movement and founding member of the Caribbean Association or Feminist Research and Action (CAFRA). She was also the seventh outstanding woman from the Caribbean Community to receive the CARICOM Triennial Award for Women, since its introduction in 1983. The award showcases and recognizes highly esteemed and outstanding women of the Caribbean for their dedication and determination in broadening the parameters of 
existence for women and improving their economic, social, political, cultural and legal status.

In her role as a political partner and ally, we can see that Elma Francois showed a personal concern for the development and the security of those in whose company she struggled. Her comrades 'looked up' to her for leadership. The organization required that men and women co-operate in developing their collective political consciousness - instituting a dynamic relationship between the sexes. One cannot but help suggest again that the manysided relations in the social organization of labour which are the lot of Caribbean women - strong arm defender of the rest, reproducer of labour power, comforter, culturiser, and producer - strengthened Elma Francois and the other women activists in the $\boldsymbol{N W C S A}$. Elma did not hold back from working with others even though there were some differences between them. She could see the larger oppression on which they were agreed and did not make the smaller conflict become an obstacle in the fight for the people to advance. ${ }^{78}$

The above text is taken from Reddock's book Elma Francois, The NWSCA and the Workers' Struggle in the Caribbean, describing Francois' life and struggle for emancipation; and her strength, intelligence and human resources of the oppressed and the doubly oppressed, is but a mirror of who Rhoda Reddock herself, is. One writer says, "We know that the future, resting in the hands of committed and conscious working people, is indeed a secure future.”79 Most people who have met and socialized with Rhoda Reddock will attest that these words are a perfect description of who she is, and the role she continues to play not only as a member of CAFRA, but the continued dedication of scholarship and teaching to women and development in the Caribbean

\footnotetext{
78 Reddock, Rhoda, Elma Francois, The NWSCA and the Workers' Struggle in the Caribbean, New Beacon Books Ltd, 1988.

${ }^{79}$ Horne, Earlene, “Women In Politics: Elma Francois” CAFRA News, November 23, 2003.
} 
Community. She has been unwavering in her promotion of Gender and Development

Studies as an important discipline in its own right.

\section{The Caribbean - Trinidad and Tobago}

\section{Hazel Brown - Network of NGO's of Trinidad and Tobago for the Advancement of} Women

Hazel Brown has spent most of her adult life as a consumer and women's affairs advocate because

of her strong belief that citizens should speak-up on

decisions, which affect their lives. She is also

motivated by the conviction that democracy is

strengthened in a society where citizens participate

actively in the decision-making process.

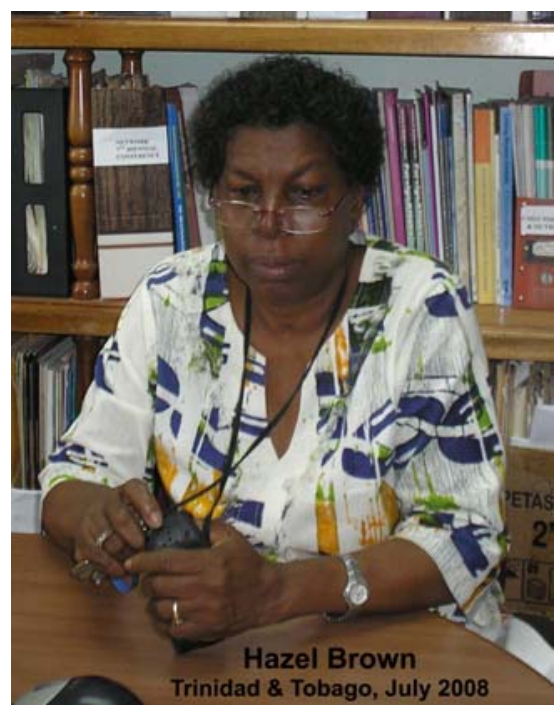

"We don't need a king at this point in time of our development. What we want is more power to the people,” said Hazel Brown, coordinator of the nongovernmental organisation, the Network of NGOs.

She told IPS that while her organisation would be playing its role in getting the population, particularly women and grassroots organisations, involved in the public discussions, it believes that any new constitution "should confine to the principles of good governance”.

"That is what we will be looking for in Trinidad and Tobago at this time - how we could have better participatory government," she said. ${ }^{80}$

An outspoken advocate of women's rights, Ms. Brown was a founding member of

the Network of NGO's of Trinidad and Tobago for the Advancement of Women, a

\footnotetext{
${ }^{80}$ Richards, Peter, President in Power Grab, Citizen Groups Say, Spiceislander.com, January 24th, 2009 http://cache.zoominfo.com/CachedPage/?archive_id=0\&page_id=1527904473\&page_url=\%2f\%2fwww.spiceislander.com\%2f\%3fp\%3d923\%23more923\&page_last_updated $=2 \% 2 \mathrm{f3} \% 2 \mathrm{f} 2009+4 \% 3 \mathrm{a} 57 \% 3 \mathrm{a} 33+\mathrm{PM} \&$ firstName=Hazel\&lastName=Brown
} 
comprehensive national umbrella organization formed in 1985 to present the position of women in Trinidad and Tobago at the End of Decade Conference in Nairobi. The Network is an advocate and support for women's organizations in Trinidad and Tobago and is part of many regional and international networks of women.

When I interviewed Ms.

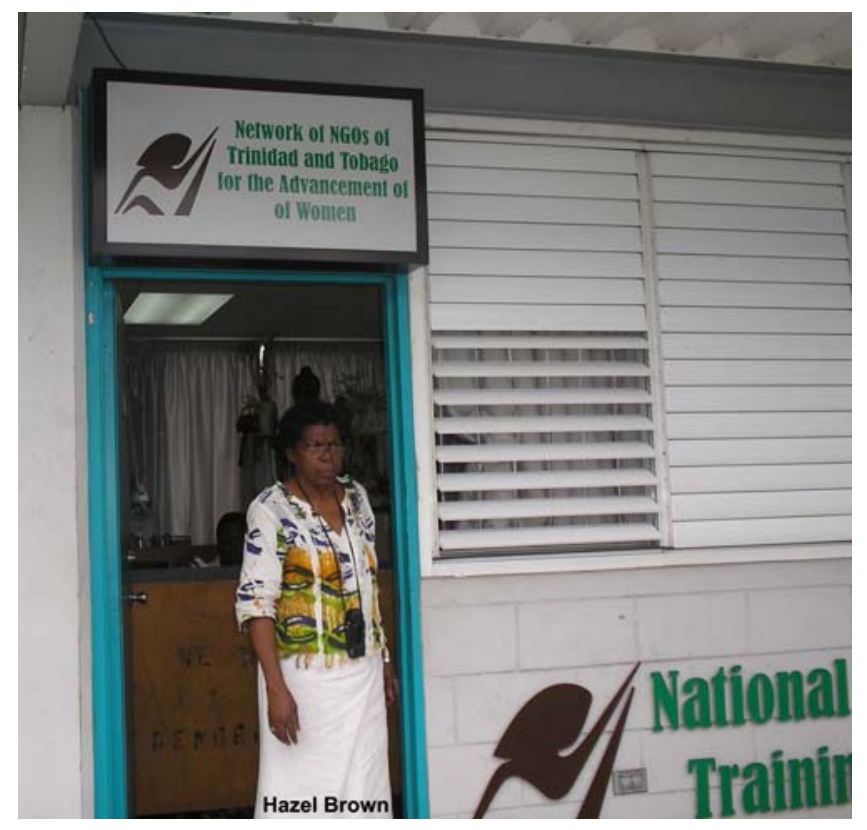
Brown in July 2008, she shared that she had concerns that the women in Trinidad and Tobago have come a long way, but there is still a lot of work to be done. She also spoke about this on the Trinidad and Tobago television show, Portfolio in December 2007.

She is a great proponent of putting women in Parliament and sponsors "Put $a$ Women", a project designed to prepare women and young people to participate in the local and general elections in Trinidad and Tobago.

Brown is also fighting against the court system in Trinidad and Tobago that sends girls to a Women’s Prison.

"Clearly there is need for facilities for girls," Brown said. "This issue must be raised in Parliament and soon I will be talking to the Leader of the Opposition to present a motion in relation to this issue. She said it was wrong to send juvenile offenders to the Women's Prison. 
An adult prison is not the place for these young girls and what now seems to be the trend in the courts cannot be right. We must make it a public issue,” Brown said, adding that she will approach "my sister", UNC senator Verna St RoseGreaves.

"We must get Verna to debate this. We have to start a campaign as the situation is getting worse and in many cases it is not that the girls are bad," she said. ${ }^{81}$

At a forum to mark the 25th anniversary of the Network of NGOs of Trinidad and Tobago, International Women's Day and Commonwealth Day, Brown says it has to be equal rights, equal opportunity; progress for all. "There can be no progress for all without a gender policy. ",82

\section{Caribbean Folklore}

\section{The Legend of Gang Gang Sarah (Tobago)}

While Tobago has a real heroine like "Ti-

Piggi”(or Mary Jane Thomas) who led the Belmanna Riots, the island was also home to Gang Gang Sarah. Tobago has many folk tales and superstitions unique to the island, including the legend of Gang Gang

Sarah. In the mountain village of Golden Lane lays the grave of Gang Gang Sarah, allegedly a "witch”

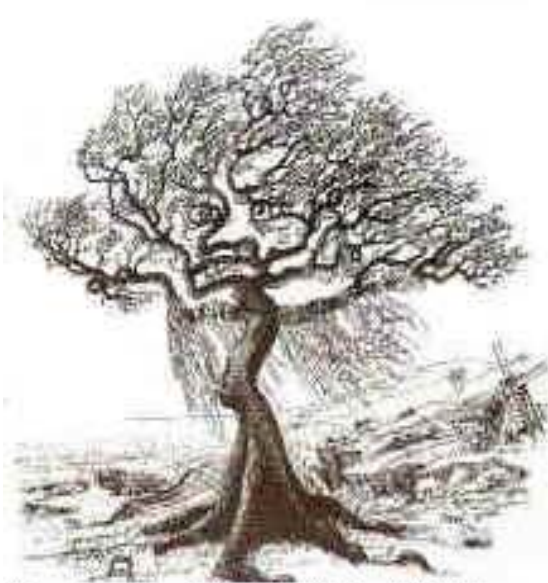

Photo courtesy Paria Publishing Co. Ltd. who flew to Tobago from Africa hundreds of years ago. After spending some time on

\footnotetext{
${ }^{81}$ Asson, Cecily, Wrong to Send Girls to Women's Prison, Trinidad \& Tobago’s Newsday, Daily News Limited, Portof-Spain, April 2, 2010; http://www.newsday.co.tt/day/1,40097.html

${ }^{82}$ Trinidad and Tobago Express, Brown: Govt Gender Policy Garbage, March 7, 2010. http://www.trinidadexpress.com/index.pl/article_news?id=161604576
} 
the island the witch tried to return home but found she was unable to fly out again because she had lost the power of flight after eating too much salt. Thus she had to be finally interred there. Another version of this same story is that one stormy night Sarah flew from Africa and landed in the Tobago village of Les Coteaux, from where she journeyed to Golden Lane in search of her family who had been transported there as slaves. There she resided and was the loving wife of Long Tom, who legend says she had known as a child in her native Africa. She lived to a ripe old age and when Tom died she thought that she would return to Africa. However, her diet would naturally contain salt as most diets do, and the story goes that she climbed the Silk Cotton tree but was unable to fly back as she had eaten salt. It's believed that she is buried under this tree, and to this day the names of Tom and Sarah can been seen inscribed upon two headstones in Golden Lane. ${ }^{83}$

Her grave can be found in the village of Culloden. The Culloden's Witch's (Gang Gang Sarah) grave is found on the top of a hillside in the village of Golden Lane. The Great Silk Cotton tree, seen as you enter the village of Culloden was originally planted by African slaves. ${ }^{84}$ It is believed to be one of the places where, under the full moon, witches would gather in the past. ${ }^{85}$ It is also rumored that Gang Gang Sarah's grave, is still used - perhaps for communication with the dead. Perhaps this is a true

\footnotetext{
${ }^{83}$ Wikipedia, The Heritage Library via the Trinidad Guardian, Web access: July 12, 2010; http://en.wikipedia.org/wiki/Gang_Gang_Sarah

${ }^{84}$ MacLean, Geoffrey, Gang-Gang Sarah, Strabon-Caraibes, Citizens for Conservation, Web access: July 12, 2010 http://rinidad-tobago.straboncaraibes.org/index.php?option=com_content\&view=category\&layout=blog\&id=14\&Itemid=44

${ }^{85}$ Besson, Gerard and Alice, Folklore and Legends of Trinidad \& Tobago, Paria Publ. Co.,2001.
} 
folktale, and perhaps shouldn't be included here in this thesis. But for some reason the rumor that her grave is still used by some to communicate with the dead (loved ones; friends), has given me the idea that she is still venerated to this day in Tobago for some reason.

\section{The USA:}

Jenny Slew (c. 1719 - ?) -- Massachusetts

Jenny Slew was born in about 1719 to a white woman and a Black man. That fact would become the core of a historic legal case forty-six years later. In 1762, Jenny Slew apparently lived as a free woman. In that year, however, she was kidnapped and enslaved. Three years later, she went to court to sue for her freedom. In most of the colonies, she would not have been able to turn to the law for help. As a slave, she would have been banned from the courts. However, by that time in Massachusetts an enslaved person could bring a civil suit. ${ }^{86}$

Jenny Slew simply stated that, because her mother was free, she was free. The lower court ruled against her, but she kept fighting. She took her case to the Superior Court. In both cases, the slaveholder attacked Slew's legal right to sue him, for any reason. He pointed out that Slew had been married. As a married woman, she had no identity separate from her husband and therefore could not sue on her own behalf. In other words, an enslaved person could appeal to the law but a married woman could not.

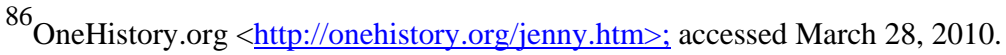


Slew almost didn't get her case to court for this reason. She had indeed been married, and more than once. She was saved by the fact that she had been married to enslaved men, so the validity of her marriages was called into question. The Superior Court agreed to hear her case. Jenny Slew won her freedom. She was also awarded court costs and damages, in the amount of four pounds. ${ }^{87}$

Elizabeth Freeman (с. 1742 - 1829), also known as Mum Bett -- Massachusetts

Just as Jenny Slew did, Elizabeth Freeman resisted being enslaved by taking her case to court in Massachusetts in order to obtain freedom, not only for herself, but for all those enslaved in that state. Elizabeth Freeman, also known as Mum Bett, could not read or write, but she could certainly think. Hearing that the newly passed state constitution declared all men equal and entitled to freedom, Freeman engaged counsel to sue for her freedom, and that of a Black man named Brom,

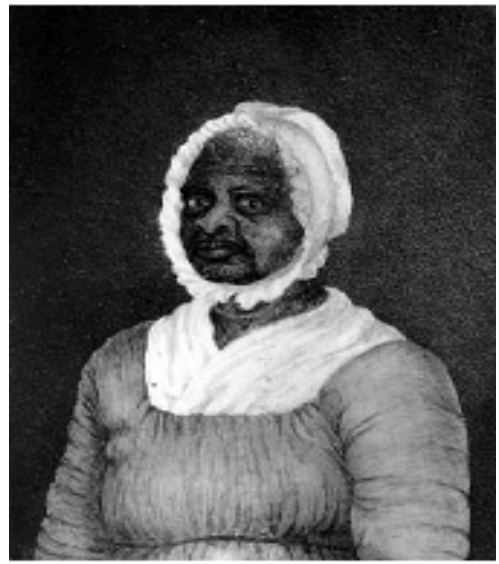

Elizabeth Freeman, 1811. A miniature painting, watercolor on ivory, done by Susan Anne Livingston Ridley Sedgwick, Freeman's lawyer's daughter. Courtesy of the Massachusetts Historical Society.

on that basis. Their enslavement, Freeman argued, violated the constitution. ${ }^{88}$ This was the first time anyone had challenged slavery by insisting that it was against a state's constitution. Amazingly, Freeman won. She and Brom were granted freedom. Not so

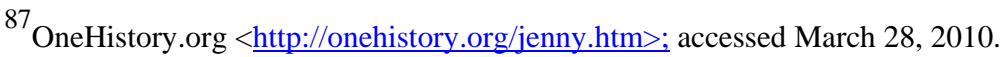

${ }^{88}$ Wikipedia Contributors. "Mum Bett." Wikipedia, The Free Encyclopedia. Wikipedia, The Free Encyclopedia, 26 Mar. 2010. Web. 29 Mar. 2010.
} 
amazingly, the suit did not free all of the slaves in Massachusetts. But the case was the first in American history that was intended to free, not a particular individual, but all enslaved people. ${ }^{89}$

Jenny Slew and Elizabeth Freeman were among the first in a long line of Black Americans who asked the law to defend their freedom and humanity. Some would be denied and some would have their petitions answered. But these two women had faith enough to fight for their freedom in a court of law, and were rewarded in their search for justice. $^{90}$

\section{Ellen Smith Craft (1826 - 1891) - Georgia}

"I had much rather starve in England, a free woman, than be a slave for the best man that ever breathed upon the American continent." Ellen Smith Craft

(All photos courtesy Georgia Women of Achievement Organization and Tubman African American Museum, Macon, GA)

\section{Ellen Smith Craft claim to}

fame is the fact she impersonated a slave holder; William Craft acted as her servant in one of the most dramatic slave escapes. $^{91}$

Ellen Smith Craft, the child
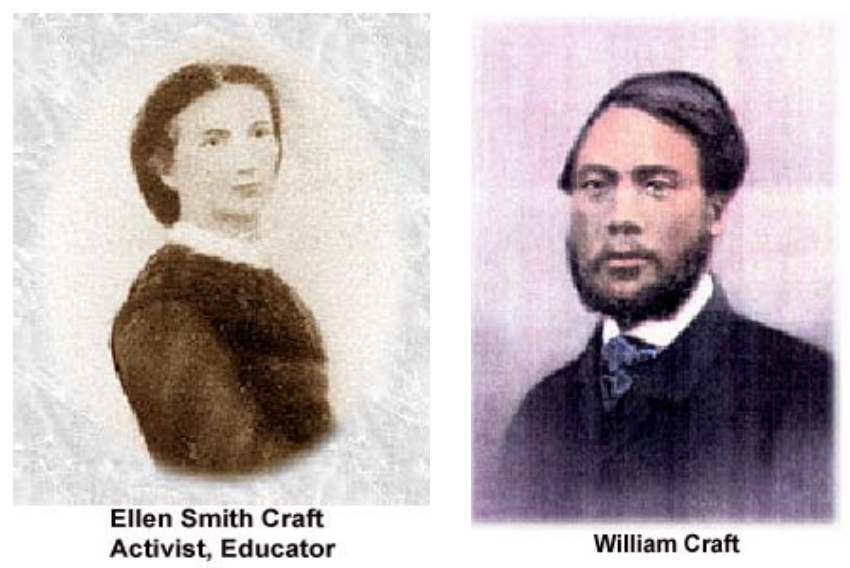

of an African American woman and her white owner, was born into slavery in Clinton,

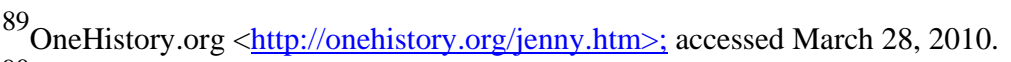
90 Ibid.

${ }^{91}$ Coleman, Kenneth and Stephen Gurr, Charles, editors, Dictionary of Georgia Biography, Athens: University of Georgia Press, 1983.
} 
Georgia. Sold, she was taken by a new owner to Macon where she met and married an enslaved man named William Craft. Together, they devised a plan to escape. With Ellen posing as William's master, they traveled by train to Philadelphia. They moved on to Boston, which was considered safer, but under the Fugitive Slave Act, their Georgia owners pursued them until they fled to England. In 1869, they returned to the South. Despite many hardships, they established a cooperative farm for former slaves and a school in Bryan County for their children. Although the projects failed and the Crafts died in poverty, Ellen is remembered for her belief in the dignity and worth of all human beings and her determination to shape a better future for succeeding generations.

Ellen Smith Craft is a Georgia woman whose life story reads like a Hollywood script of adventure and courage: an unlikely escape from the shackles of slavery followed by the selfless pursuit of justice despite continuing threats to her own safety and wellbeing.

She was born in 1826, in the town of Clinton, GA just a few miles east of Macon. Her mother was an African American slave named Maria; her father was her mother's white owner and master, Col. James Smith. Ellen’s skin was very light and she was often taken for a member of her white family. It is easy to imagine what an unhappy relationship she must have had with her mistress, the wife of Col. Smith. At age eleven she was given to her half-sister as a wedding present upon that sibling's marriage to Dr. Robert Collins of Macon. Ellen met her own husband-to-be there. William Craft was 
also enslaved, and his family had been broken up and sold to pay its master's gambling debts. In Macon he belonged to a banker who apprenticed him out as a carpenter so as to earn money from his labor.

Ellen and William were allowed to marry in 1846, but they could not live together since they belonged to different owners. They endured this separation for a while but soon began to save money and plan an escape. While their plan seems incredible, it worked. Ellen disguised herself as a white gentleman, placing her arm in a sling to cover her inability to write, and wrapping her head in a bandage to hide

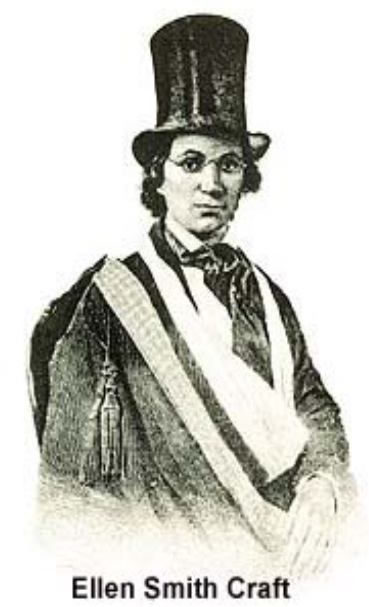
her lack of beard. She pretended to be traveling, first-class, to Philadelphia for medical treatment. William went as her slave. After several harrowing encounters, they got to Savannah by train, took a boat to Charleston and then the train again, to Maryland.

Once in free territory, they made contact with an Abolitionist group. Ellen stayed with a Quaker family in Philadelphia who nursed her through a serious illness. But for safety they moved on to Boston, the main center of the Abolitionist movement, where they supported themselves through their trades, cabinet-making for William and sewing for Ellen. Both became active in the abolitionist movement and gained fame on the lecture circuit; stories about them were published in The New York Herald, The Boston Globe, and the Georgia Journal and The Macon Telegraph. 
After passage of the Fugitive Slave Act, which permitted the forcible recapture of ex-slaves from the free states, the Crafts were no longer safe in Boston. Ellen's former owner, Dr. Collins, sent two slave catchers to hunt her down. An ex-slave group called the League of Freedom protected Ellen and William from that threat, but they decided to flee to England, going overland to Maine to catch a boat from Canada since the Boston ports were being watched.

They lived in England for seventeen years, and their five children were born there. After a lecture tour during which news accounts reported that audiences had been moved to tears by their story, William and Ellen went to an agricultural school in Surrey, broadening their skills, and eventually teaching. But though they were offered the positions of superintendent and matron of the school, they chose to move to London, believing it was important to demonstrate that ex-slaves could be self-sufficient. When visitors from the southern United States spread rumors of her desire to return to the security of her former home in Georgia, Ellen issued what became a famous disclaimer:

"I had much rather starve in England, a free woman, than to be a slave for the best man that ever breathed upon the American continent."92

Once the Civil War was over, however, and the slaves emancipated, Ellen and William came back to the South, having raised funds to start a cooperative farm for exslaves as a way of freeing them from the contract labor system; they also planned to develop a school for children. The Ku Klux Klan burned out their first establishment,

\footnotetext{
${ }^{92}$ Coleman, Kenneth and Stephen Gurr, Charles, editors, Dictionary of Georgia Biography, Athens: University of Georgia Press, 1983.
} 
and white opponents used slander to destroy their second. Their school, at which Ellen was teaching seventy-five children free of charge, was forced to close.

Ellen died in 1891, and a few years later the farm she and her husband had started was auctioned off to pay William's debts. He died one month later. Ellen Craft was not content simply to gain her own freedom. Through her belief in the dignity and worth of all human beings she helped to shape a better future for succeeding generations. On March 21, 1996, Ellen Craft was named a Georgia Woman of Achievement. ${ }^{93}$

\section{Carlotta Walls LaNier (1942 - ) -- The Little Rock Nine}

\section{Carlotta Walls LaNier made}

history as the youngest member of the

Little Rock Nine, the nine African-

American students who desegregated

Central High School in Little Rock

(Pulaski County) in 1957.

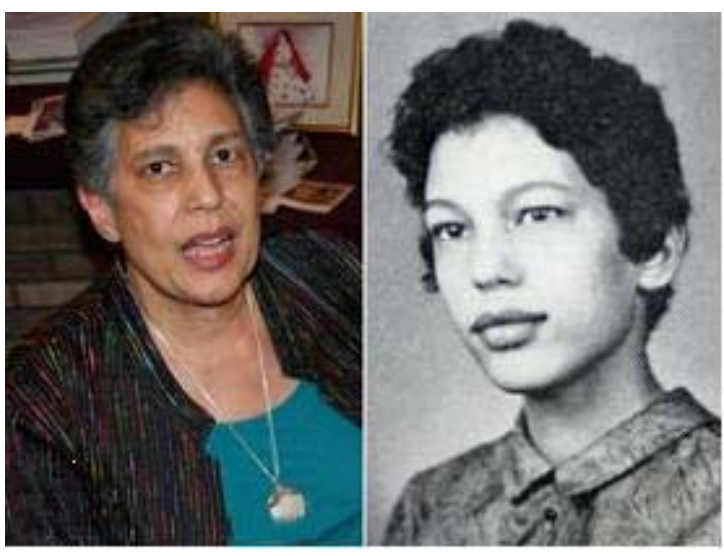

She was the oldest of three daughters, born on December 18, 1942, in Little Rock to Juanita and Cartelyou Walls. Her father was a brick mason and a World War II veteran, and her mother was a secretary in the Office of Public Housing. ${ }^{94}$

\footnotetext{
93 Kenneth Coleman and Charles Stephen Gurr, editors, Dictionary of Georgia Biography, Athens: University of Georgia Press, 1983.

${ }^{94}$ Cobb, William H. "Commonwealth College.” The Encyclopedia of Arkansas History \& Culture. 21 Oct. 2004 http://www.encyclopediaofarkansas.net/encyclopedia/entry-detail.aspx?entryID=10
} 
Inspired by Rosa Parks, whose refusal to give up her bus seat to a white passenger sparked the 1955 Montgomery, Alabama, bus boycott, as well as the desire to get the best education available, Walls enrolled in Central High School as a sophomore. Some white students called her names and spat on her, and armed guards had to escort her to classes, but she concentrated on her studies and protected herself throughout the school year. Walls and every other Little Rock student were barred from attending Central the next year, when all four Little Rock high schools were closed, but she returned to Central High and graduated in $1960 .^{95}$

Walls attended Michigan State University for two years in the early 1960s before moving with her family to Denver. (Her father could not get work locally after the 1957 crisis.) In 1968, she earned a BS from Colorado State College (now the University of Northern Colorado) and began working at the Young Women's Christian Association (YWCA) as a program administrator for teenagers. ${ }^{96}$

Also in 1968, Walls married Ira C. "Ike" LaNier, with whom she had a son and a daughter. In 1977, she founded LaNier and Company, a real estate brokerage firm in Denver. She currently resides in Englewood, Colorado.

LaNier was awarded the prestigious Spingarn Medal by the National Association for the Advancement of Colored People (NAACP), along with the other Little Rock Nine and Daisy Bates, in 1958. She has also served as president of the Little Rock Nine

\footnotetext{
${ }^{95}$ Cobb, William H. “Commonwealth College.” The Encyclopedia of Arkansas History \& Culture. 21 Oct. 2004 http://www.encyclopediaofarkansas.net/encyclopedia/entry-detail.aspx?entryID=10

${ }^{96}$ Ibid.
} 
Foundation, a scholarship organization dedicated to ensuring equal access to education for African Americans, and is a trustee for the Iliff School of Theology and the University of Northern Colorado. In 1999, President Bill Clinton presented the nation’s highest civilian award, the Congressional Gold Medal, to the members of the Little Rock Nine. ${ }^{97}$

\section{Before Rose Parks there was...}

Claudette Colvin (1940 - )

Before Rosa Parks, 15-year-old Claudette

Colvin refused to give up her seat on the bus.

Nearly everyone in the world knows who Rosa

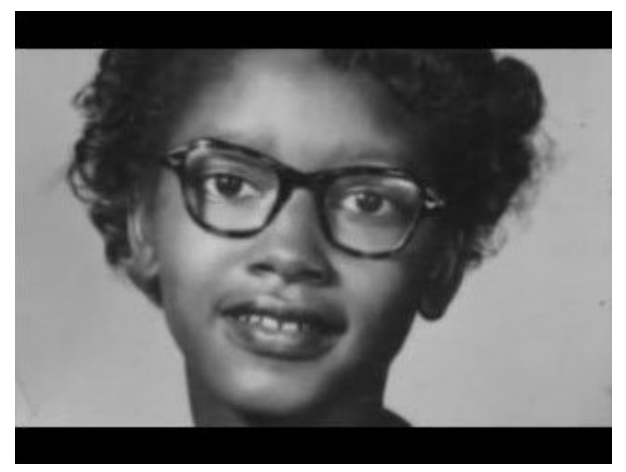

parks is, but what about Claudette Colvin? On March 2, 1955, nine months before Parks famously refused to give up her seat on a bus in Montgomery, Alabama, a skinny, 15year-old schoolgirl was yanked by both wrists and dragged off a bus very much like Rosa Parks was on. ${ }^{98}$

Unless one has studied the Montgomery Bus Boycott beyond the basic education given in school, it's fair to say that the name Claudette Colvin is unknown. Possibly her

\footnotetext{
${ }^{97}$ Cobb, William H. “Commonwealth College.” The Encyclopedia of Arkansas History \& Culture. 21 Oct. $2004<$ http://www.encyclopediaofarkansas.net/encyclopedia/entry-detail.aspx?entryID=10 >

${ }^{98}$ Gray, Eliza, Civil Rights: A Forgotten Contribution, NEWSWEEK, March 2, 2009.
} 
name has been seen as a postscript to Rosa Parks's story. But, Ms. Colvin deserves her own place in history. So, why doesn't she have it? ${ }^{99}$

Phillip Hoose, in his book, Claudette Colvin: Twice Toward Justice (2009), describes how the girl stood her ground, yelling, "It's my constitutional right”, all the while the cops were pulling her off the bus, and proceeded to throw her into the back of a cop car, handcuffing her through the window. Hoose's tells how a teacher named Geraldine Nesbitt had emboldened her students, teaching them about the 14th Amendment. And during an interview with Newsweek, Colvin said, "It just so happens they picked me at the wrong time-it was Negro History Month, and I was filled up like a computer. I felt like Sojourner Truth was pushing down on one shoulder and Harriet Tubman was pushing down on the other-saying, 'Sit down girl!' I was glued to my seat.”

Today, Claudette Colvin is 69 years old and is a nurse at a retired nursing-home, where she lives in New York City. Colvin's bold actions have all but been largely forgotten and long ago eclipsed by Rosa

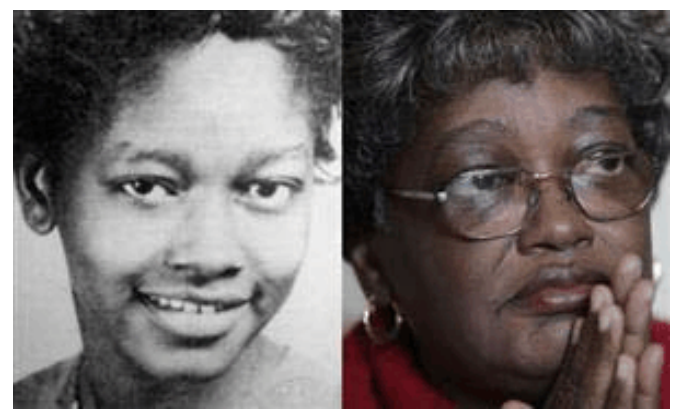
Parks. "I just dropped out of sight,” she says of her move to New York in 1958. "The people in Montgomery, they didn't try to find me. I didn't look for them and they didn't

\footnotetext{
99 Tircuit, Angela, Before Rosa Parks, There was Claudette Colvin, Associated Content, August 15, 2006 http://www.associatedcontent.com/article/51163/before_rosa_parks_there_was_claudette.html?cat=38
} 
look for me.” In the years that followed her heroism, Colvin felt completely isolated from the Alabama activists who had once been so interested in her case. ${ }^{100}$

But Hoose says that Colvin's dramatic arrest did not go unnoticed; energized by the prospect of using her case to challenge the segregation laws in court, black leaders hired 26-year-old Martin Luther King Jr., an ambitious young lawyer to defend her and raised funds from the community for her trial. King accompanied black leaders to the police commissioner to plead her case. But Colvin was convicted nonetheless, and the news tore across Montgomery. There was talk of a bus boycott, as African-Americans made up three fourths of the passengers and the Women's Political Council; headed by Jo Anne Robinson (a professor at the historically black Alabama State College) had long known a boycott would be their most powerful weapon. ${ }^{101}$

But according to Hoose, leaders were unsure about Colvin. He describes their thoughts at the time: “'Some felt she was too young to be the trigger that precipitated the movement,' wrote Robinson. E. D. Nixon, an influential black leader who was heavily involved with the case. 'I had to be sure that I had somebody I could win with'.”

Hoose believes that despite Colvin's lack of fame, she was an instrumental predecessor to Rosa Parks's actions (which occurred nine months later). Before Colvin, Hoose told Newsweek, civil-rights leaders in Montgomery had been taking measured steps. Colvin "threw the stone in the water and forced them to jump in and think about

\footnotetext{
${ }^{100}$ Tircuit, Angela, Before Rosa Parks, There was Claudette Colvin, Associated Content, August 15, 2006 http://www.associatedcontent.com/article/51163/before_rosa_parks_there_was_claudette.html?cat=38

${ }^{101}$ Hoose, Phillip M., Claudette Colvin, Twice Toward Justice, Farrar, Straus and Giroux (BYR), 2009.
} 
what they had to do," he explains. Colvin's attorney, Fred Gray, a civil-rights activist who still practices law in Alabama, agrees: "Claudette gave all of us moral courage. If she had not done what she did, I am not sure that we would have been able to mount the support for Mrs. Parks.”102

Hoose goes on to say that when Parks was arrested on December 1, 1955, Montgomery was ready. Within days, Robinson Nixon and the Women's Political Council had organized a wildly successful and crippling bus boycott, and snapped the whole country to attention. Unlike Colvin, Parks was a refined and a grand-motherly seamstress completely above reproach—she was the face that leaders had been searching for.

In the meantime, Colvin remained anonymous, Hoose says. She knew Rosa Parks, often spending the night at her house after weekly NAACP youth meetings, which she had gotten involved with after her arrest. Sometime during the summer of 1955, Colvin became pregnant by an older, married man. Nixon said later that the pregnancy was part of the reason activists chose not to use Colvin as the face of their boycott. Yet, in May 1956, Colvin testified with three other women in a successful class-action suit that ultimately desegregated the Montgomery buses.

Hoose makes it clear that he hopes his book will introduce Claudette Colvin's contributions to a larger audience. "I want it to be impossible to tell the story of the civilrights movement without Claudette” he says. "Rosa Parks has to scoot over a little bit.”

${ }^{102}$ Gray, Eliza, Civil Rights: A Forgotten Contribution, NEWSWEEK, March 2, 2009. 
The civil-rights movement was made up of a million tiny acts by anonymous individuals. I was glad to learn during my research, that Claudette Colvin was one of those anonymous individuals and is still alive today. There is no denying that Rosa Parks deserves her place in history. But, those that came before should have more than a footnote in the history books. One of those people is Claudette Colvin.

\begin{tabular}{|l||}
\hline \multicolumn{1}{|c||}{ Before Rosa } \\
(for Claudette Colvin) \\
A resistant blossom at fifteen \\
Before Rosa, you refused \\
To be moved and shoved; loudly screaming. \\
The color of your skin dictated your fate \\
Before Rosa, you experienced \\
The wrath of those who hate. \\
Give Rosa kudos, she deserves many \\
But you at a young age, before her, \\
Also resisted, but didn't receive any. \\
You deserve your own space in history \\
After facing ridicule and jail \\
Let me tell your story; and no mystery. \\
Why not celebrate Claudette, give her a \\
voice \\
And help children learn \\
That before Rosa, you also made a choice. \\
Clare J. Washington \\
(C11/15/09
\end{tabular}




\section{Before Rose Parks there was also ...}

\section{The Women of the Montgomery Bus Boycott (Civil Rights Movement)}

(The Women Who Started the Boycott: Jo Ann Gibson Robinson, T. M. Glass, Z. J. Pierce and Irene West)

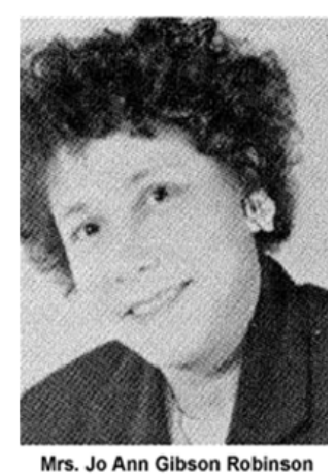

Mrs. Jo Ann Gibson Robinson

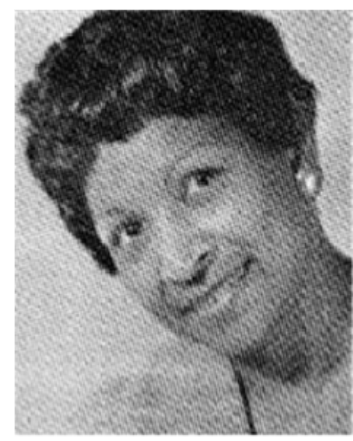

Mrs. T. M. Glass

Mrs. T. M. Glass

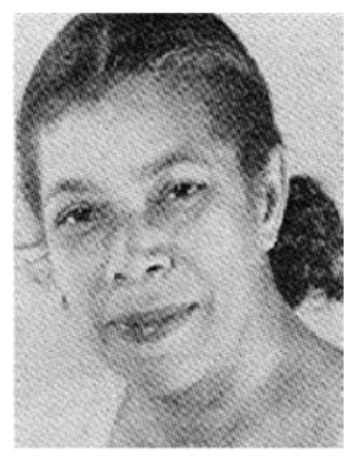

Mrs. Z. J. Pierce

Mrs. Z. J. Pierce

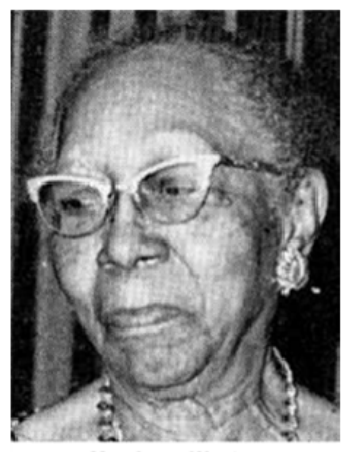

Mrs. Irene West

Mrs. Irene West

By the time of the March on Washington in 1963, the only nationally recognized black women acceptable to the civil rights coalition were the distinguished roster of black singers! -Noble $\left(1978\right.$, p. 140) ${ }^{103}$

Maintaining the invisibility of Black women and our ideas is critical in structuring patterned relations of race, gender and class inequality that pervade the entire social structure. -Collins (1991, p. 5) ${ }^{104}$

When thinking of the civil rights movement, the name that most often comes to mind is that of the charismatic leader, Martin Luther King, Jr. Those more familiar with the movement and its history would add the names of Ralph Abernathy, James Forman, Andrew Young, Jesse Jackson, and the Southern Christian Leadership Conference

\footnotetext{
${ }^{103}$ Noble, J., Beautiful, Also, are the Souls of My Black Sisters: A History of the Black Woman in America. Englewood Cliffs, NJ: Prentice Hall, 1978.

${ }^{104}$ Collins, Patricia H., Black Feminist Thought: Knowledge Consciousness and the Politics of Empowerment. New York: Routledge, 1991.
} 
(SCLC). Rarely, if ever, would the names of Jo Ann Gibson Robinson, Septima Clark, Dnita Blackwell, Ella Baker, the Women's Political Council, or Amelia Platts Boynton be mentioned. Was the civil rights movement essentially built and operated by men such that the role performed by women need only be remembered as a footnote in history? Is the absence of women an insignificant peculiarity of the time period? Is it merely hysterical feminist revisionism that motivates the need to acknowledge the women who gave life to the movement, nurtured it through its formative stages, and continues to support its various permutations today? ${ }^{105}$

Black women in Montgomery, Alabama, unlocked a remarkable spirit in their city in late 1955. Sick of segregated public transportation, these women decided to wield their financial power against the city bus system and, led by Jo Ann Gibson Robinson (19121992), convinced Montgomery's African Americans to stop using public transportation.

Jo Ann Gibson Robinson was born in Georgia and attended the segregated schools of Macon. After graduating from Fort Valley State College, she taught school in Macon and eventually went on to earn an M.A. in English at Atlanta University. In 1949 she took a faculty position at Alabama State College in Montgomery. There she joined the Women's Political Council. When a Montgomery bus driver insulted her, she vowed to end racial seating on the city's buses. Using her position as president of the Council, she mounted a boycott.

\footnotetext{
${ }^{105}$ Nance, Teresa A., Hearing the Missing Voice, Journal of Black Studies, Vol. 26, No. 5, Special Issue: The Voices of African American Women in the Civil Rights Movement (May, 1996), pp. 543-559.
} 
She remained active in the civil rights movement in Montgomery until she left that city in 1960. Her story illustrates how the desire on the part of individuals to resist oppression — once it is organized, led, and aimed at a specific goal — can be transformed into a mass movement.

The role of Black women in the civil rights movement was significant. By many accounts, Black women developed, organized, and sustained the movement. Recently, greater academic attention has been focused on rediscovering the contributions of these Black women (Crawford, $1990 ;{ }^{106}$ White, 1990) ${ }^{107}$. The importance of this kind of historical refocusing is not simply to add women's names to the litany of civil rights heroes. Rather, the activism of Black women reflects a usefully unique orientation to the process of political organizing for the purposes of changing social policy. Even more important, recognizing the work of civil rights women (and the conditions under which the work was enacted) adds to an understanding of Black women's collective experiences. Black feminist scholars have long argued for the inclusion of Black women's experiences into the data banks of culture. Bell Hooks (1981) writes,

No other group in America has so had their identity socialized out of existence as have black women. We are rarely recognized as a group separate and distinct from black men or a present part of the larger group "women" in this culture. $(\text { p. } 7)^{108}$

\footnotetext{
${ }^{106}$ Crawford, V., Beyond the Human Self: Grassroots Activists in the Mississippi Civil Rights Movement. In V. L. Crawford, J. A Rouse, \& B. Woods (Eds.), Women in the Civil Rights Movement: Trailblazers and Torchbearers, 1941-1965. New York: Carlson, 1990.

${ }^{107}$ White, J., Black Leadership in America from Booker T. Washington to Jesse Jackson (2nd ed.). New York: Longman, 1990.

${ }^{108}$ Hooks, B., Ain't I a Woman?. Boston: South End, 1981.
} 
After all is said and done, we must recognize the strategic organizational role of Black women in the civil rights movement. Through a close analysis of the specific activities of Black women acting individually and collectively, it is shown that many of the roles played by Black women during this time period were a continuation of historical roles played out in slavery and reconstruction.

JoAnn Gibson Robinson, T. M. Glass, Z. J. Pierce, Irene West and all of the other Black women in the civil rights movement were a powerfully present force whose contributions constructed the ground out of which many advancements in social justice were structured. The time has long since passed that what these women achieved be recognized and acknowledged.

Rosa Parks (1913 - 2005)

Rosa Parks is one of the most famous women in American history. Her refusal, in 1955, to give up her seat on a Montgomery bus to a white person sparked the

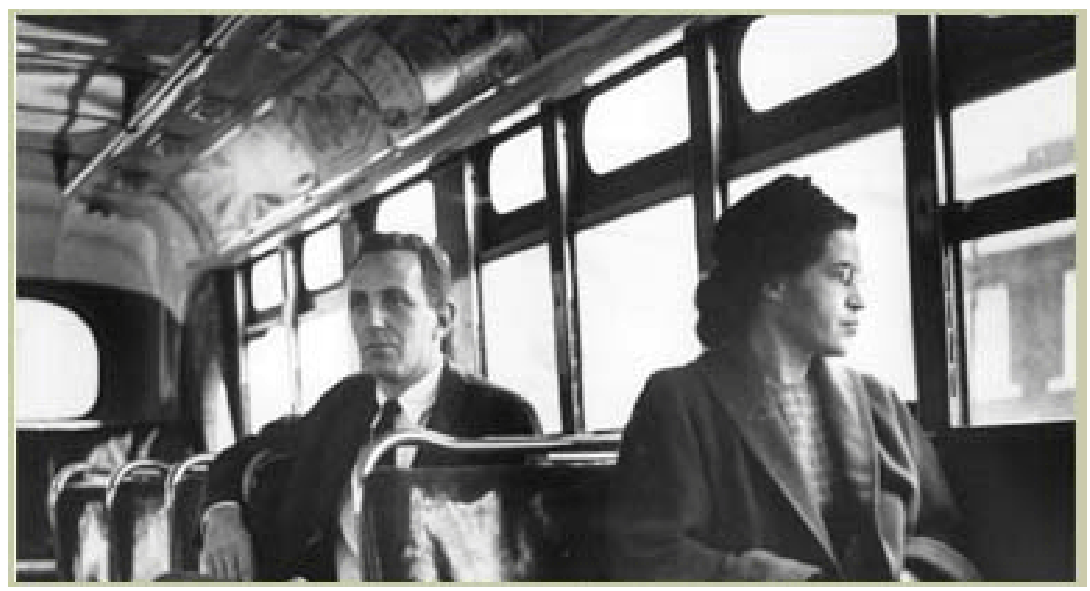

Montgomery Bus

Boycott. A year later, with much hardship and violence, the boycott ended, and black and white people could sit where they wanted. Mrs. Parks became a heroine to the Civil Rights Movement. 
But, she wasn't the first to take a stand, by refusing to stand. Before Rosa Parks, there was Claudette Colvin.

Most historians date the beginning of the modern civil rights movement in the United States to December 1, 1955. That was the day when an unknown seamstress in Montgomery, Alabama refused to give up her bus seat to a white passenger. This brave woman, Rosa Parks, was arrested and fined for violating a city ordinance, but her lonely act of defiance began a movement that ended legal segregation in America, and made her an inspiration to freedom-loving people everywhere. ${ }^{109}$

The bus incident led to the formation of the Montgomery Improvement Association, led by the young pastor of the Dexter Avenue Baptist Church, Dr. Martin Luther King, Jr. The association called for a boycott of the city-owned bus company. The boycott lasted 382 days and brought Mrs. Parks, Dr. King, and

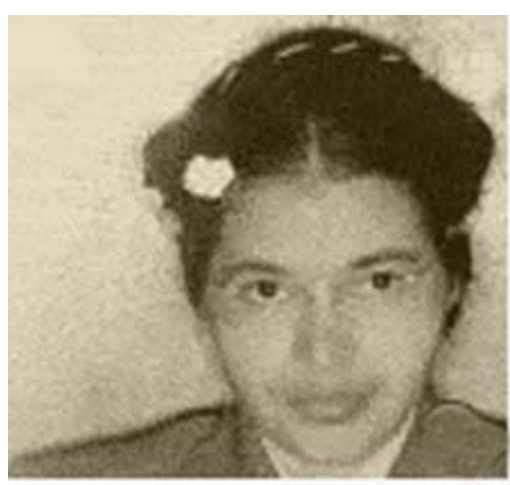
their cause to the attention of the world. A Supreme Court Decision struck down the Montgomery ordinance under which Mrs. Parks had been fined, and outlawed racial segregation on public transportation.

\footnotetext{
${ }^{109}$ Tircuit, Angela, Before Rosa Parks, There was Claudette Colvin, Associated Content, August 15, 2006 http://www.associatedcontent.com/article/51163/before_rosa_parks_there_was_claudette.html?cat=38
} 
In 1957, Mrs. Parks and her husband moved to Detroit, Michigan where Mrs.

Parks served on the staff of U.S. Representative John Conyers. The Southern Christian Leadership Council established an annual Rosa Parks Freedom Award in her honor. ${ }^{110}$

\section{The USA - Chicago and New York}

\section{Lillian Davis Roberts - Hospital Strike Organizing in the 1950s}

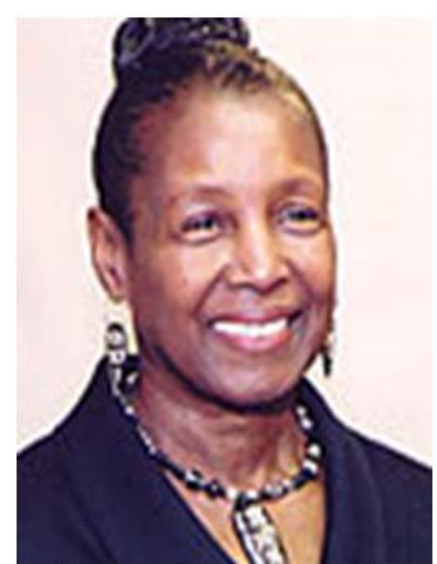

Lillian Roberts (1933-) Executive Director
District Council 37, AFSCME, AFL-CIO
Womanpower has always been the manpower of the health system, and, in particular, of the hospital. Today, 75 percent of all health workers are women. Historically, the women who worked in the hospitals were poor, immigrants, or blacks; throughout much of the nineteenth century they were even prisoners or inmates of the city asylums, forced to work in the adjacent hospitals. ${ }^{111}$

Lillian Davis Roberts began her career as a nurse's aide in Chicago. She became the first African American woman to be elected Executive Director of District Council 37, American Federation of State, County, and Municipal Employees Union (AFSCME), the largest municipal union in New York City, in 2002. The union has 121,000 members and 50,000 retirees.

\footnotetext{
${ }^{110}$ Tircuit, Angela, Before Rosa Parks, There was Claudette Colvin, Associated Content, August 15, 2006 http://www.associatedcontent.com/article/51163/before_rosa_parks_there_was_claudette.html?cat=38

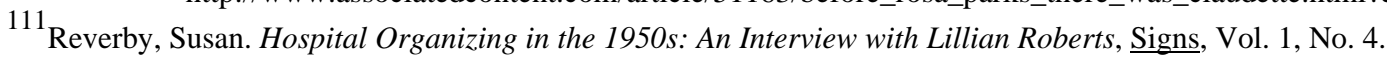
(Summer, 1976), pp. 1053-1063.
} 
Lillian Roberts was one of the first black nurse's aides in a large Chicago hospital in the late 1940s. During World War II, the aide positions moved from being the domain of volunteer, upper-class women to being the job of poor, often black--women. As shortages and turnover became more prevalent in the hospitals, the conditions of work for these women worsened. ${ }^{112}$

Roberts was one of five children. Her family lived in a very large tenement building, in a sort of a ghetto, in Chicago. From the time she was two years old until she turned eighteen and a half, they were on welfare. She attended what she says were regular ghetto schools, and managed to get a scholarship to the University of Illinois. But after six months, she had to return home and find a job, because her brother was drafted and there was no longer any money for the family.

While in high school, she washed dishes in a Catholic hospital, and then was a nurse's aide, working very long hours after school and getting paid \$11.00 every two weeks. In 1946, Roberts was able to obtain a job at the University of Chicago Lying-in Hospital. At that time, it was an all-white setup in terms of nurse's aides. However, the nursing supervisor hired some blacks because she was no longer able to get whites, as the job didn’t pay well. During the war, the defense jobs drained off a lot of the best personnel, primarily because they paid more. ${ }^{113}$

\footnotetext{
${ }^{112}$ Washington, Clare, Lillian Davis Roberts, The African American National Biography, Henry Louis Gates and Evelyn Brooks Higginbotham, eds., Oxford University Press, 2008.

113 Ibid.
} 
Since the hospital had had no black nurse's aides before, Roberts was isolated because the whites wouldn't have anything to do with her. The doctors would look in the window of the nursery at her like she was on exhibit or something. She worked in the nursery for about three or four years, and then she was given the responsibility for the surgery of newborn babies' circumcisions. She was considered an excellent worker, and was left with the student nurses on the weekend, which she says she enjoyed. But she soon got bored when there was nothing else to learn, so she asked for a transfer to the emergency part of the hospital, thinking it would be a challenge.

Because she was very good at every job she learned in the different areas, she got an assignment that actually required two or three nurse's aides. She would do her work upstairs and then race downstairs to work with the patients. This was an everyday occurrence, so Roberts asked her shop steward if she would file a grievance for her.

There was a workers' union at the hospital, but it was a pretty weak union according to Roberts. It was the only hospital that had a union at that time in Chicago. The workers would get raises like a penny and a half an hour, and the shop steward at that time was afraid to go in and fight for them.

By 1956, the situation at the hospital had changed and the majority of the aides were black. They were enduring what was considered an over-work load without being properly compensated for it. When her boss began piling on more and more work, refusing to hire more staff, Roberts complained to her union, Local 1657 of the University of Chicago Employees Union. The union did not speak up for these workers. 
Roberts was finally persuaded to take on the position of shop steward, and was elected by the workers. In fact, she held a series of elected and staff positions until 1968, when she became the second in command of the country's largest municipal union as associate director of DC 37 in New York City.

Roberts says that being a shop steward, makes a person tough. She faced an atmosphere of plain, outright discrimination designed to make her feel very inferior.

Roberts became the organizer of the first hospital strike in Chicago's history. It lasted six months, and there was a lot of violence, and some fighting. This was the result of some people (scabs) who were being paid to do the workers' jobs. Most of the strikers were women, because in most hospital settings it is mostly women. But most of these women were black. A lot of them were the sole support of their families. At the beginning there were a few men, but they left for other jobs because they had the responsibility for taking care of their families and really didn't know where the money was going to come from.

Roberts says the strike was a civil rights action because blacks were underpaid and being kept in low-paying jobs. They would never have gotten anywhere without organization, and the instrument for it was a union.

Lillian Roberts arrived in New York in 1965 to organize low-paid and often disrespected hospital workers for the American Federation of State, County, and Municipal Employees (AFSCME). ${ }^{114}$ At the time, AFSCME was competing with the 
Teamsters to represent the health workers, and the struggle was intense. An AfricanAmerican woman, who had grown up on welfare in Chicago, Roberts proved adept at organizing hospital workers, many of whom were African-American women. She and AFSCME prevailed, paving the way for District Council 37 to become the dominant New York municipal union. "Putting women in leadership positions ensures that women are able to represent their own interests,” says Roberts, during an interview with Susan Reverby. ${ }^{115}$ "They know what their concerns are." What women bring to the table, according to Roberts, is a concern for the small things as well as the overall picture (Newsday, September 2, 2002). She says the environment for union women has changed. Early on, she recalls being ignored by male colleagues in meetings she attended with her supervisor. She explains that they would avoid making eye contact with her, and she was hesitant to contribute to discussions while "the good old boys" were talking. In 1969, Roberts was jailed for two weeks for defying New York Governor Nelson Rockefeller and leading a strike against three mental hospitals.

In 1981, she left the union and was appointed New York State Labor Commissioner, the first black woman to hold such a high post in New York. From 1987 to 1992, she was senior vice president of Total Health Systems, an HMO. In 2002, as DC37 was involved in a major scandal in the late 1990's, Roberts returned to DC37 as Executive Director. She negotiated two successful contracts for the union, created an

\footnotetext{
114 “The Momentum Was Catching On:” Lillian Roberts Describes Organizing Hospital Workers in New York City. Courtesy of the Wagner Labor Archives; History Matters, U.S. Survey Course on the Web, http://historymatters.gmu.edu/d/6944/
} 
affordable housing program for members, and returned the union to the respected and powerful position it had held before the scandals. In 2007 the New York Post named her one of the 30 most powerful African American leaders in New York City.

On Jan. 23, 2007, District Council 37's delegates overwhelmingly re-elected Lillian Roberts to a third term as executive director.

\section{Mae Wall Miller - One of the Last Slaves in Mississippi}

Cain Wall and his family claimed they were held in slavery until 1961. Slavery which was abolished in 1863 (1865 in Texas) continued in a tiny rural town in

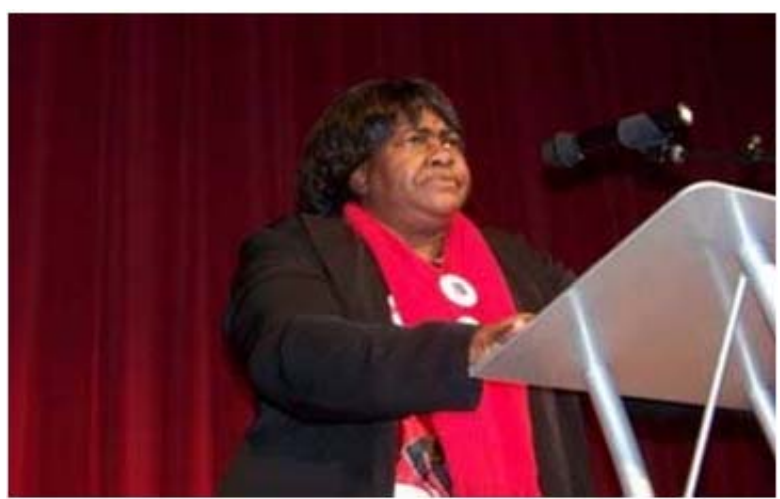

Mae Wall Miller

(Photo courtesy Antoinette Harrell)

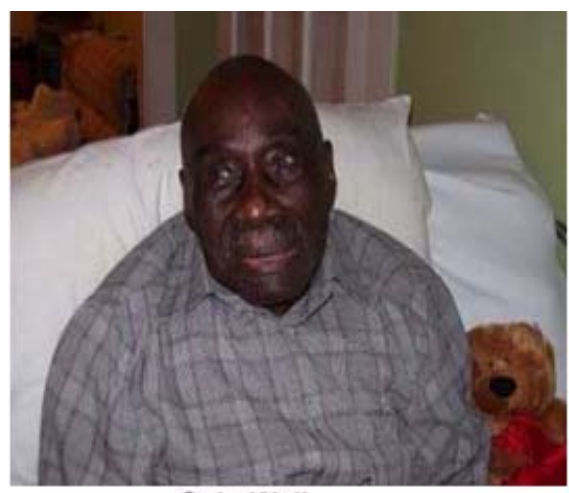

Cain Wall

(Father of Mae Wall Miller)

Mississippi. This tiny town in Gillsburg, Mississippi was void of electricity, phone, or radio, and trips into town were forbidden for the Walls. The Wall family had no idea that they were free even though Black families in nearby Liberty, Mississippi, owned businesses and attended school.

\footnotetext{
${ }^{115}$ Reverby, Susan, Hospital Organizing in the 1950s: An Interview with Lillian Roberts, Signs, Vol. 1, No. 4. (Summer, 1976), pp. 1053-1063.
} 
Mae Wall and her family lived in a remote setting in Mississippi, far from cities or even roads, not being able to read or write and completely cut off from outsiders. The story Miller tells is harrowing, and when s she tells it at any venue, you can hear a pin drop. $^{116}$

Miller tells how she and her family were treated worse than dogs. How they all spent their every waking moment "picking cotton, pulling corn, picking peas, picking butter beans, picking string beans, digging potatoes; whatever it was, that's what you did for no money at all." How the "Boss's" table scraps were tossed into a tub for days and then set out under a tree for them to eat out of like hogs. And how the only drinking water they had access to, was from a creek that was green with slime and whatever else might be floating in it. How they never had a spoon or a toothbrush or shoes. How, when they laid down to sleep at night, exhausted, on the dirt floor of their bare-bones shack, her father, Cain Wall, (seen in the photo above at nearly 105 years of age) would lie flat on the dusty earth and the rest of the family would lie perpendicular to him, using his body (even when it was bloody) as the only pillow they ever knew. Mae talks about how she was raped so often and so brutally as a child that it left her incapable of having children herself. How they were beaten routinely and viciously and threatened with death if they even thought about trying to leave. How they were assured that if they did break free, the ones they left behind would be murdered.

\footnotetext{
${ }^{116}$ Changekeeper, “Why Am I Not Surprised?: The Art of Re-Enslavement,” July 1,2008, http://whyaminotsurprised.blogspot.com/2008/07/art-of-re-enslavement.html
} 
What's even more surprising is when you hear Mae Wall say, "We thought all Black people were being treated like that," she now remembers. "So where were we going to go?"117

Cain Wall Sr. was born in 1902 into peonage in St. Helena Parish, LA. He worked the fields and milked cows for white families while believing he had no rights as a man. Peonage is a system where one is bound to service for payment of a debt. It was an illegal system that flourished in the rural South after slavery was abolished. Mr. Wall was born into this system believing that he was bound to these people that held him and his relatives captive. Being unable to read and write also stifled any opportunity that may have presented itself to the Mr. Wall, because he was unable to decipher anything.

During World War II, Mr.

Wall decided to run away, but eventually was captured and brought back into slavery.

Mr. Wall's daughter, Mae Miller remembered some of the most violent details of their time in captivity. She

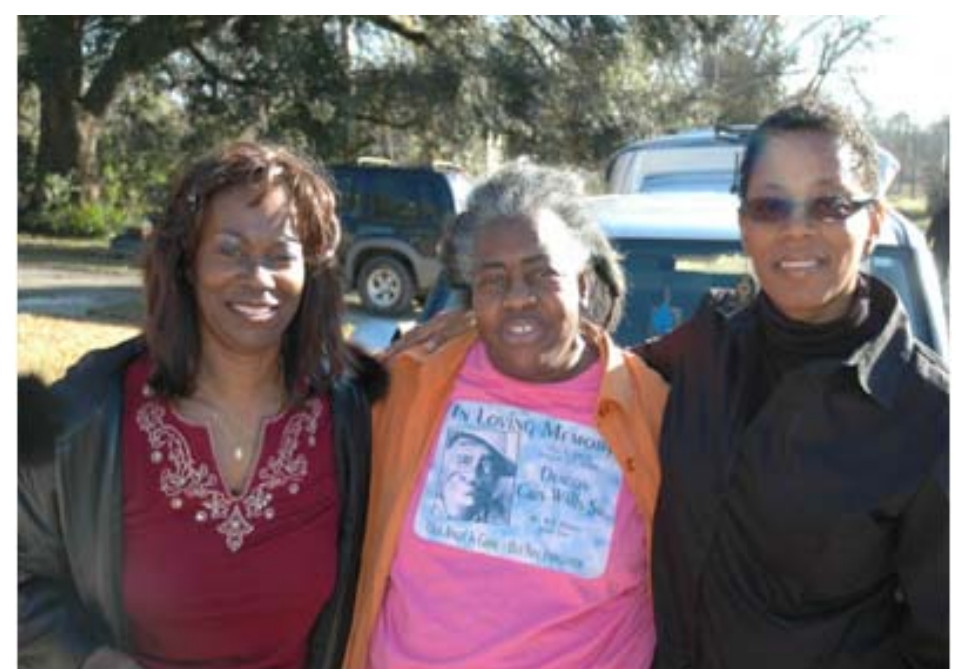

Clare, Mae Wall Miller, Antoinette Harrell (Photo courtesy C.J. Washington) recalled the beatings that her father and members of her family received. According to

\footnotetext{
${ }^{117}$ Changekeeper, “Why Am I Not Surprised?: The Art of Re-Enslavement,” July 1,2008, http://whyaminotsurprised.blogspot.com/2008/07/art-of-re-enslavement.html
} 
People Magazine they were beaten with whips or even chains for slacking off. In the Magazine, Mae's older sister who is now 65 years old stated, “The whip would wrap around your body and knock you down.” Mae also recalled how once her father was beaten so badly that she and her siblings climbed on his body to protect him. For Mae Miller the most violent of crimes happened when she was five years old. In the magazine, she vividly remembered one day going to clean the house with her mom, and being accosted by two white males who raped her and her mother. She remembered a woman from the Gordon family which held them as slaves yelling to the two white males to leave her alone because she was only a yearling. That did not deter these two devils because they continued to rape a five year old, totally destroying this young woman's soul. Years later Mae was told that she would be unable to have kids because of the damage done to her. ${ }^{118}$

Mae found freedom in 1961 when she ran away at the age of 18 after refusing to do the chores. In People Magazine she stated, “I don't know what got into me. I remember thinking they're just going to have to kill me today, because I'm not doing this anymore.” 119

It was difficult for the Wall family to acclimate to the world outside. Isolated for so long, they found it hard to trust people outside of the family. Mae Miller has learned to read and write, but she says her feet still don't wear shoes easily. Nevertheless, the Wall

\footnotetext{
${ }^{118}$ Changekeeper, “Why Am I Not Surprised?: The Art of Re-Enslavement,” July 1,2008, http://whyaminotsurprised.blogspot.com/2008/07/art-of-re-enslavement.html

${ }^{119}$ Ibid.
} 
family has moved on and Mae has bonded now with Antoinette Harrell, and joined her in her work to make the world aware that the slavery of African-Americans in the United States (also called "peonage" or "involuntary servitude") is far from dead even yet.

\section{Antoinette Harrell-Miller - Gathering of Hearts}

When Antoinette Harrell began studying her family history, she had the arduous task of talking to elder members of her family and poring over public records. As part of her family history research, she decided to also have her DNA checked. She discovered that she is descended from the Tuareg Tribe in Western Africa. But this didn't just become an interesting tidbit for her to discuss at family barbeques. It

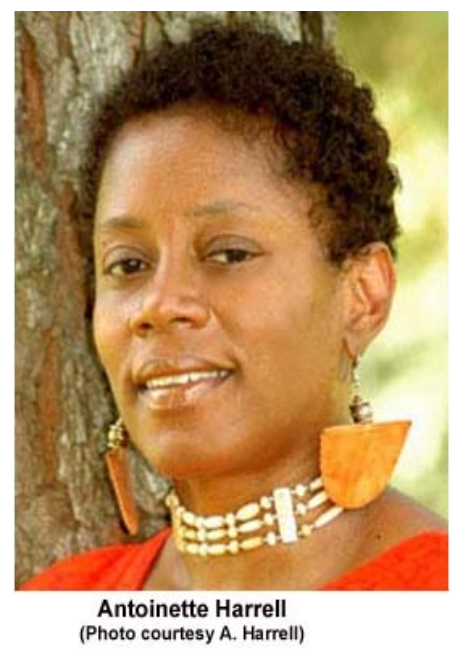
became the motivating force to send her to spend a month with the Tuareg in Niger, West Africa, reconnecting to her past. ${ }^{120}$

In the process of this personal historical journey, however, Harrell developed an ever deepening sense of what African-Americans have suffered in this country over the past five hundred years.

Many people are very skeptical about what Antoinette Harrell uncovered in her search for the truth about enslaved African Americans-even after slavery had

\footnotetext{
${ }^{120}$ Changekeeper, “Why Am I Not Surprised?: The Art of Re-Enslavement,” July 1,2008, http://whyaminotsurprised.blogspot.com/2008/07/art-of-re-enslavement.html
} 
supposedly ended with the signing of the Emancipation Proclamation in 1863. "Slavery ended over a hundred years ago," they flatly state, as if mildly irritated. "What does that have to do with us today?" ${ }^{121}$ ? Antoinette herself has discovered the answer to this question, in the form of old courthouse records and old records from the Department of Justice. Still, those who are skeptical, find it hard to believe that African Americans were still enslaved in some states, just as Mr. Cain Wall and his family were, up until the 1960s. Simply put, many of us just aren’t ready to believe such an atrocious act could have continued into the twentieth century.

The fact is that even if slavery did end a hundred years ago (and Harrell and others argue that it did not), the effects of it, don't just linger on, but actually run rampant through the lives of all U.S. citizens. ${ }^{122}$ Harrell's documentary, “The Untold Story: Slavery in the 20th Century" sheds more light on the plight of many African Americans still enslaved after the Emancipation Proclamation was signed.

Some years ago, at one of Harrell's many speaking engagements on the importance of tracking family history (even the painful parts), she was approached by Mae Louise Wall Miller (who I refer to in this study as One of the Last Slaves in Mississippi), who told Harrell that she was raised in what amounted to slavery and only escaped in 1963 - one hundred years after slavery had ended!

\footnotetext{
${ }^{121}$ Changekeeper, “Why Am I Not Surprised?: The Art of Re-Enslavement,” July 1,2008, http://whyaminotsurprised.blogspot.com/2008/07/art-of-re-enslavement.html

122 Ibid.
} 
Harrell has spent literally hundreds of hours crawling through private collections and public documents from the National Archives in Washington, D.C., to the dusty, batinfested attics of Court Houses in the rural South. She has found Justice Department records documenting cases of White people being prosecuted well into the twentieth century for holding people in involuntary servitude. She has copied more than 30,000 documents: case records, letters from people in bondage, and even letters to officials as high up as the President of the United States from lawyers and other credible sources (including the N.A.A.C.P.) requesting investigation of peonage in sixteen states. She has learned that the Department of Homeland Security now holds former F.B.I. files further documenting such cases under investigation as late as the 1970 's. ${ }^{123}$ "Unfortunately (and not surprisingly, under the circumstances), these files are closed to the public," Harrell laments. One reason these files might be closed is that Harrell and Miller, among others, have brought a class action suit demanding reparations. Not primarily personal reparations, but reparations to benefit the entire African-American community because of their centuries of unpaid labor, because of the physical, emotional, psychological, and economic devastation from the on-going effects of the past, and most importantly, because individual cases like that of the Wall family demonstrate that the paradigm of White Supremacy still functioning in this country has allowed these effects to continue into the present. ${ }^{124}$

\footnotetext{
${ }^{123}$ Changekeeper, “Why Am I Not Surprised?: The Art of Re-Enslavement,” July 1,2008, http://whyaminotsurprised.blogspot.com/2008/07/art-of-re-enslavement.html

${ }^{124}$ Ibid.
} 
Antoinette Harrell and Ines Soto Palmarin organize Poverty Tours through their Gathering of Hearts organization. They also deliver food and clothing to destitute families in Mississippi. She is busy with her on-going projects and research, but is never too busy to make sure that those living below the poverty level in the Mississippi Delta have what they need with resources for standard living: clean water, affordable housing, health care, 21st century education, jobs, recreation programs for the youth and public transportation.

Antoinette Harrell's goal is to continue bringing about awareness of enslaved people (African Americans, in particular) well into the twentieth century, and how this form of involuntary servitude or "peonage” still has an effect on many of those still living in impoverished conditions today in the Mississippi Delta and portions of Louisiana. ${ }^{125}$

\section{American Folklore (Voodoo Queens) Marie LaVeau, Mammy Pleasant, Sanite Dede}

Just as the Caribbean has real women heroines and folktales (such as the legend of Gang Gang Sarah), the U.S. also has folktales surrounding women who are sometimes responsible for the unexplainable. As with anything or anyone that society and its people cannot understand, rumors and half-told truths usually abound. Such is the case of two voodoo queens - Marie LaVeau of New Orleans, Louisiana, and Mary Ellen Pleasant, better known as “Mammy Pleasant” of San Francisco, California.

\footnotetext{
${ }^{125}$ Washington, Clare, “Interview with Antoinette Harrell”, Kentwood, Louisiana, January 28. 2009.
} 
According to Robert Tallant (Voodoo in New Orleans), women have always ruled

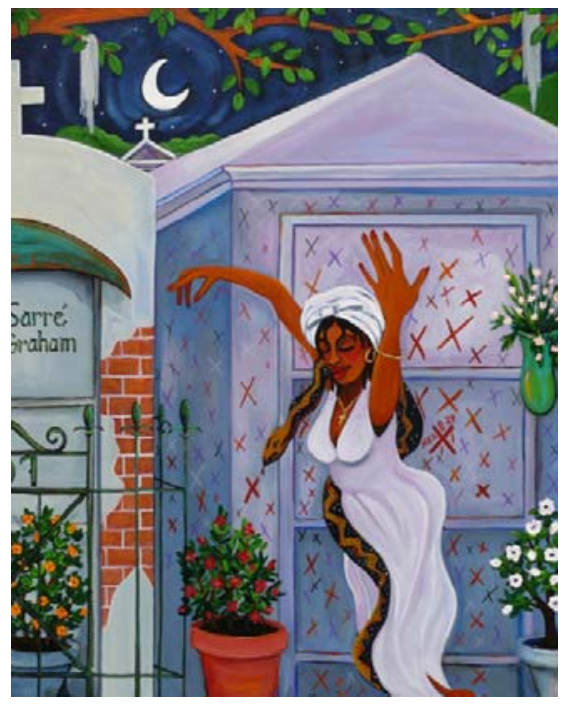

Voodoo, but there are very few authentic records of

the early Voodoo queens. There are two reasons for

this. The first is because of Marie Laveau, who was

the leader of Voodoo for about seventy-five years in

New Orleans. The other reason is that in the

beginning, Voodoo changed significantly from one

year to the next. Also another possibility is that since

there had to be so much secrecy involved with the

practice of Voodoo in the early years that maybe even the Voodoos didn't even know the real identity of who the queen was. ${ }^{126}$

Marie LaVeau (1801-1881; also written as Laveaux)

Marie LaVeau was the most famous voodoo queen of

New Orleans. She was at her height from the 1830s to the 1850s

and has since become a figure of legend. There are at least eight

songs about her, like “The Witch Queen of New Orleans” (1971)

by Redbone. She even appears as a character in Marvel Comics

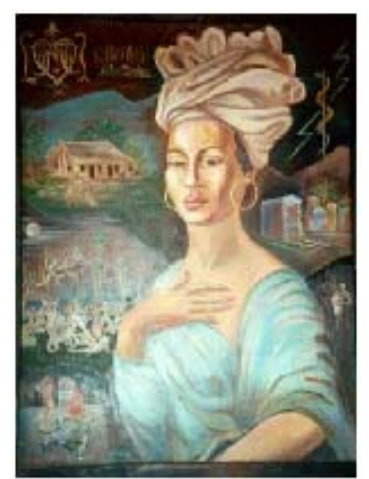

Marie LaVeau (as a white witch in black latex). ${ }^{127}$ However, there seems to be some debate about her actual birth date. Some sources indicate that Marie was born in Santo Domingo

\footnotetext{
${ }^{126}$ Tallant, Robert, Voodoo in New Orleans, Pelican Publishing, 1984; 1994.

${ }^{127}$ Dwyer, Jeff, Ghost Hunter's Guide to New Orleans, Pelican Publishing, 2007.
} 
sometime between 1783 and 1794. Her date of death is June 16th, 1881, which some say is seemingly impossible for someone to live until almost 100 years old in that day and age. She was married to a man named Santiago Paris in August of 1819. Shortly after, Paris died before they could even have any children together. Within a year of his death, Marie married Captain Christophe Duminy Glapion. They had 15 children together, and in order to support such a large family she began to work as a hair stylist, working in the homes of the French Quarter's wealthiest. ${ }^{128}$

She was Creole, one of the French-speaking people of New Orleans, and a quadroon too, meaning she was one-fourth black. Her father was a white planter, her mother was half white and half black (and maybe part Native American too). Laveau was a free person of colour: he could own property but could not marry a white person. She was also a believing Catholic and even went to mass every day. It was common in those days for people to believe in both Catholicism and voodoo at the same time.

It is said that in New Orleans, her ghost may be the most elusive in all of the Crescent City. Her legacy in life can be found virtually in every shop, souvenir stand, bar, and of course the House of Voodoo in New Orleans. Her ghost is sometimes seen in St. Louis Cemetery No. 1, outside her old cottage on St. Ann Street, and walking along the levee overlooking the Mississippi River. It is also believed that the ghost of Marie walks among those who attend church on St. John's Eve, the most important day on the Voodoo calendar. Many people believe to this day that the power of Marie Laveau is still as

\footnotetext{
${ }^{128}$ Dwyer, Jeff, Ghost Hunter's Guide to New Orleans, Pelican Publishing, 2007.
} 
strong as it ever was. This is evidenced by those that say (whether myth or fact), that if you visit her grave and draw "XXX" on it with chalk, you can make a wish, and she will see that your wish is granted. ${ }^{129}$

As a voodoo queen, Laveau healed the sick, told fortunes and sold "gris-gris”, a voodoo charm. For $\$ 10$, you could buy a love powder. For up to $\$ 1000$ she would use

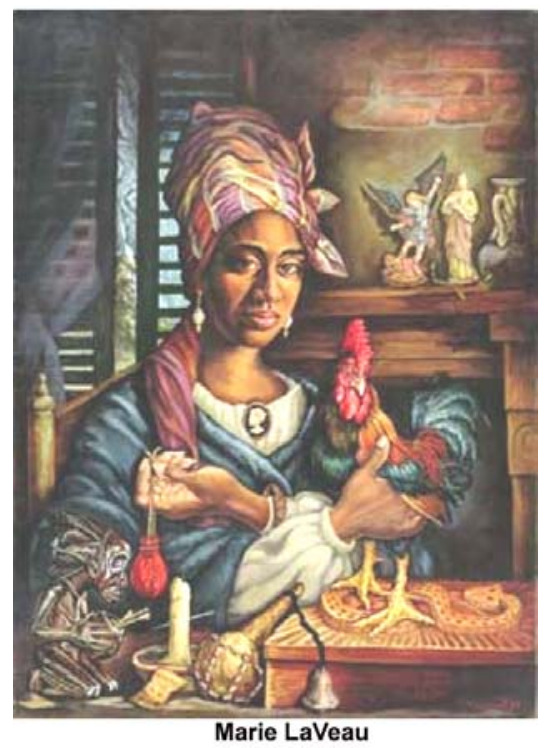
voodoo to help you win an election. She also sported a snake around her neck. Some say her power came less from voodoo or any kind of magic and more from knowing the right things about the right people: she was a hairdresser who worked for the wives of the top men in New Orleans. It seems likely she knew all about their love affairs and business deals - either from the wives themselves or from their servants.

It is hard to know where fact ends and fiction begins with her. In what seems to be the truest story a man came to her desperate because his son was about to be sentenced to death by a judge. He offered to give her a house. A few days later, to everyone’s surprise, the son got off, and was no sentence was pronounced at all.

\footnotetext{
${ }^{129}$ Dwyer, Jeff, Ghost Hunter's Guide to New Orleans, Pelican Publishing, 2007.
} 

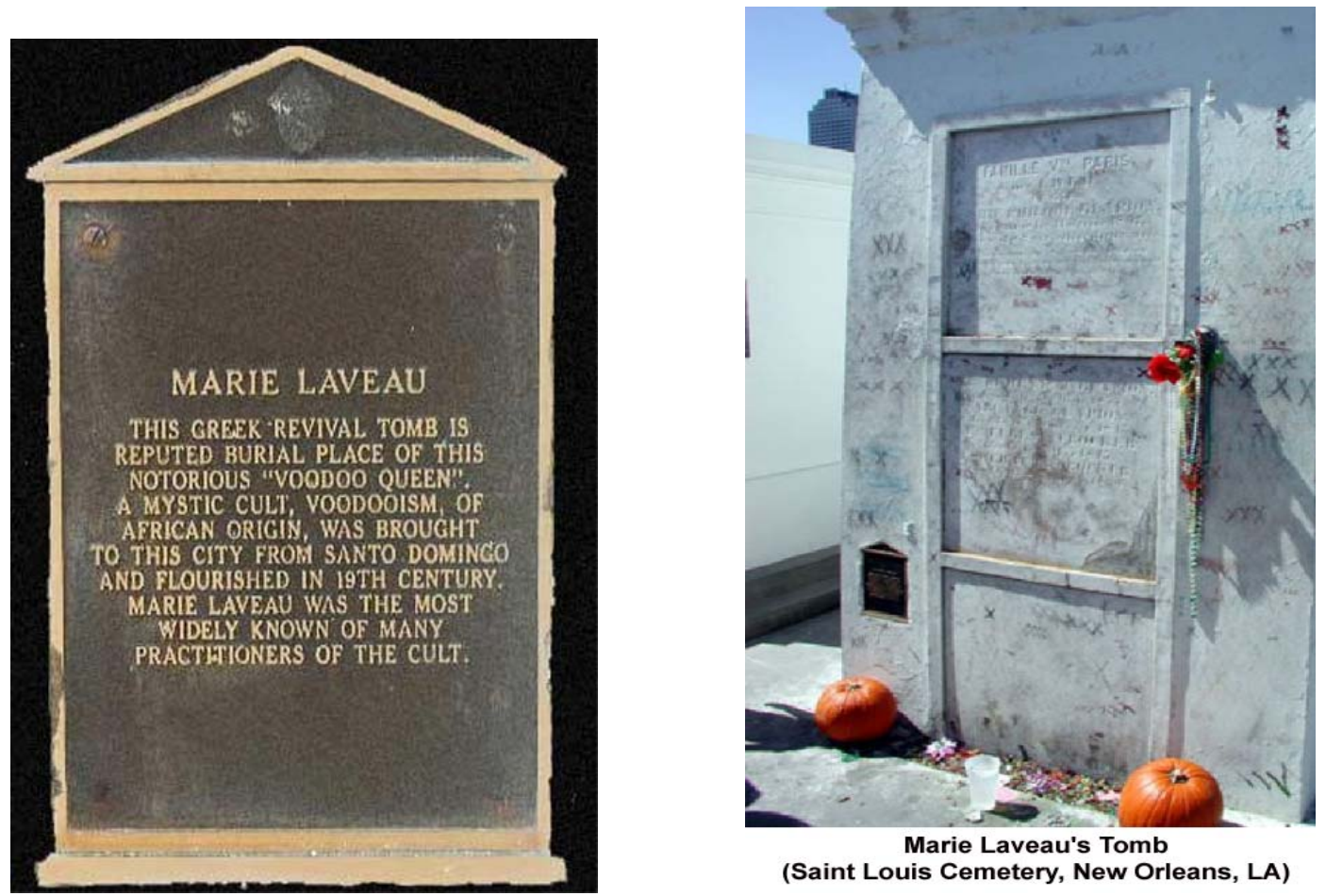

Marie Laveau's Tomb

(Saint Louis Cemetery, New Orleans, LA)

\section{MAKE A LOVE WISH ON MARIE LAVEAU'S TOMB}

How to make a wish on Marie Laveau's* tomb:

1. Download the picture below to your hard drive (or print it out).

2. Open the picture in any paint program you have (not necessary if you have printed it out.)

3. Somewhere on the tomb, make three red $X$ 's side by side (XXX).

4. Knock on the picture three times.

5. Ask Marie Laveau outloud to grant your love wish. (Example: "Beautiful Marie Laveau, love queen of New Orleans, please grant my wish that Johnny love me.")

6. Exit your paint program without saving the picture OR if you printed the picture, fold it up (picture inward) and burn it or throw it in running water.

7. The same day that you make a wish, make an offering of fruit, flowers, or candy to Marie Laveau by leaving them in a cemetery. 
Her unique powers caused her to be sought out by women and men of wealth and power in New Orleans, seeking her special brand of Voodoo magic. Today, her tomb is a focal point of special wishes and offerings by New Orleanians swearing that she still grants her favors even today. She is most famous for granting love wishes. ${ }^{130}$

Marie LaVeau also had a daughter of the same name who looked very much like her. She is known as Marie Laveau II. She too, was a voodoo queen. It is hard to tell where the mother leaves off and the daughter begins. It seems likely the daughter took over in the 1860s.

There were sightings of her after she died. Some may have been her daughter, but some took place even after she had died too. Laveau's ghost is said to appear on St John's Eve, June 23rd, wearing a handkerchief with seven knots. She was able to bridge the gap between Voodoo practitioners and the religious values of the people of the French Quarter by including Catholic symbols in her ceremonies. Her ghost has also been seen along stores on Rampart Street. There was one time when she allegedly slapped a man in the face for taking too long to pay for his items in one of the shops. The Laveau cottage on St. Ann Street is also believed to be haunted by the Voodoo priestess.

\section{Mary Ellen "Mammy" Pleasant (1814?-1817? - 1904)}

Mary Ellen Pleasant was born a slave on a plantation near Augusta, Georgia. She became an important western terminus of the Underground Railroad in San Francisco

\footnotetext{
${ }^{130}$ Dwyer, Jeff, Ghost Hunter's Guide to New Orleans, Pelican Publishing, 2007.
} 
during the 1850s. By placing maids and servants throughout the homes of San Francisco's rich, she came to wield (secret) power among San Francisco's elite. ${ }^{131}$

When Mary Ellen was 10, her mother gave her the name of her white plantationowning father, and also disclosed that Mary Ellen was descended from a succession of

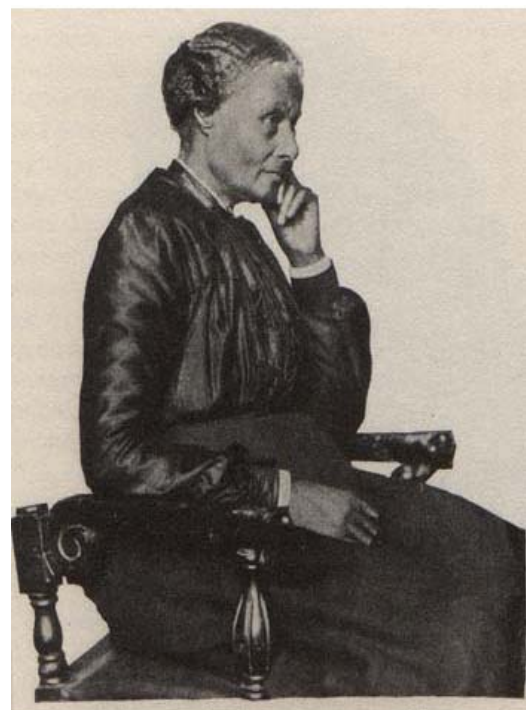

Mary Ellen Pleasant left her mark on San Francisco. This photo, taken when she was 87 , accompanied her 1902 autobiography. Photo courtesy of the Bancroft Library, University of California, Berkeley
Voodoo Queens of Santo Domingo. A year later, Mary

Ellen was sold to a man in New Orleans, Americus

Price, and he decided to place her in a convent where she would be educated, and eventually freed. Later he sent her to live with friends in Cincinnati, since her educated intelligence would have eventually betrayed her in the antebellum South. There seems to be different stories of where Mammy Pleasant was born. According to her various memoirs, Pleasant, was born a slave near Augusta, Georgia between 1814 and 1817, and according to ships records and confirming testimony, she arrived in San Francisco in April, 1852 to escape persecution under the Fugitive Slave Law of 1850, for slave rescue work in the East. However, the courage to do that and other great deeds started in childhood. $^{132}$

\footnotetext{
${ }^{131}$ The Butcher's Floor, Mammy" Pleasant - San Francisco Voodoo Queen (1814-1904), August 21, 2006. http://butchersfloor.blogspot.com/2006/08/mammy-pleasant-san-francisco-voodoo.html

${ }^{132}$ Bibbs, Susheel, Heritage of Power (Marie LaVeau/Mary Ellen Pleasant, MEP Publications; 1st edition, 1998.
} 
At birth, Mary had no last name. In her first memoir she said that she was born the illegitimate child of a Virginia governor's son (John H. Pleasants) and an enslaved Haitian voodoo priestess, so Mary had to create names for herself. ${ }^{133}$ After witnessing the death of her mother at the hand of a plantation overseer, Mary had to make her way largely on her own. In another of her own memoirs, she claimed that her mother was a voodoo priestess, descended from a long line of "voodoo queens" of Santo Domingo. In her autobiography, published in 1902, Mary Ellen Pleasant states: “Some people have reported that I was born in slavery, but as a matter of fact, I was born in Philadelphia.”134 She was very fair-skinned, so she "passed" for white a good portion of her lifespan, especially when began her dealings with the elite in San Francisco, California. She was also one of the most controversial figures in San Francisco life during the late nineteenth century; Mary Ellen "Mammy" Pleasant had a reputation that ran the gamut from savior of the downtrodden to exploiter of the wealthy. In an article in Ebony Magazine, Lerone Bennett, Jr.,calls her "a bold black pioneer who was one of the most enigmatic and mysterious women in American history."135 Various reports in leading newspapers of her day called her everything from the "Queen of Voodoo" to a blackmailer, organizer of orgies, and one of San Francisco's most notorious madams.

Pleasant played a key role in court cases on major civil rights issues as well as in sensational cases involving purported murder, infidelity, and forgery. However, much of

\footnotetext{
${ }^{133}$ Bibbs, Susheel, Heritage of Power (Marie LaVeau/Mary Ellen Pleasant, MEP Publications; 1st edition, 1998. 134 Ibid.

${ }^{135}$ Ebony Magazine, June 1993, pp. 56, 58-60, 62, 64; September 1993, pp. 52, 54, 56, 58, 60, 62.
} 
her story can neither be confirmed nor disproved due to a lack of tangible evidence and her own closely guarded secrecy regarding the details of her life.

Mary Ellen's life took her in and out of various families and situations in New England and Virginia. She married James W. Smith, a Virginia plantation-owner and abolitionist. Throughout the late 1830s and early 1840s Mr. and Mrs. Smith smuggled hundreds of slaves to Canada as couriers along the Underground Railroad. When Smith died in 1844, Mary Ellen continued to outrage southern planters by helping scores of slaves to escape. ${ }^{136}$

Things became too hot and Mary Ellen made her way first to New Orleans where Marie Laveau, the voodoo queen, deeply impressed Mary Ellen with her social power among all levels of New Orleans society. Mary Ellen stayed in New Orleans for a few months and learned about the practice of voodoo from Marie Laveau, though she didn't plan to copy Laveau's version exactly. By 1852, Louisiana planters were urgently searching for Mary Ellen Pleasant as the crafty intrigante who would stop at nothing in smuggling slaves through the "Underground". ${ }^{137}$

She sometimes visited plantations dressed as a jockey, other times as a shabby man on a delivery wagon. After getting trained as a cook, Mary Ellen found a job on a local plantation, right under the noses of the local gentry. Overhearing speculation about

\footnotetext{
${ }^{136}$ Hudson, Lynn M., The Making of "Mammy Pleasant": A Black Entrepreneur in Nineteenth-Century San Francisco, University of Illinois Press; 1st edition, 2002

${ }^{137}$ Ibid.
} 
her origins one night, Mary Ellen made a hasty escape, and took the four-month sea journey around Cape Horn, arriving in San Francisco on April 7, 1852. On the journey she met a Scottish fellow named Thomas Bell, over whom she would maintain a powerful influence throughout the next three decades, as they both became millionaires speculating on mining and banking interests.

When Mary Ellen arrived in San Francisco (known as Yerba Buena briefly), she passed as white, using her first husband's name among the whites, and took jobs running exclusive men’s eating establishments starting with the Case and Heiser establishment. She met most of the founders of the city as she catered lavish meals and she benefited from the tidbits of financial gossip and deals usually tossed around at the tables. She engaged a young clerk, Thomas Bell, at the Bank of California and they began to make money based on her tips and guidance. Thomas made money of his own, especially in quicksilver and by 1875 they had amassed a 30 million dollar fortune between them. J. J., who had worked with Mary Ellen from the slave stealing days to the civil rights court battles of the 1860s and 70's, died in 1877 of diabetes. ${ }^{138}$

Controversy over Pleasant's life was heightened more or less permanently after she became the housekeeper for Thomas Bell. Pleasant had moved with Bell and his wife, Teresa, into a 30-room mansion that Pleasant had supposedly designed. The Bell home became known in San Francisco as "The House of Mystery," and the rumor mill

\footnotetext{
${ }^{138}$ Hudson, Lynn M., The Making of "Mammy Pleasant": A Black Entrepreneur in Nineteenth-Century San Francisco, University of Illinois Press; 1st edition, 2002.
} 
ground out all manner of theories about the relationship between Pleasant and Bell. The housekeeper was cast in the role of everything from Bell's lover to a cunning thief who extorted significant sums from the Bell fortune. ${ }^{139}$

Pleasant appeared to have control over the finances of the Bells that far exceeded the typical boundaries of housekeeping. Her name turned up on the deed to the Bell homestead, and some newspaper reports indicated that Pleasant cheated money out of the family coffers with an assortment of scams. She may have used some of the money she secured from the estate to help the plights of blacks, and she told the San Francisco Examiner that she often brought food to churches and hospitals. However, other reports stubbornly maintained that all her "charity" was directed toward her own financial gain. ${ }^{140}$

Although Mary Ellen passed for white, she did not conceal her race from other blacks and was adept at finding jobs for those brought in by Underground Railroad activities. Some of the people she sponsored became important black leaders in the city. She left San Francisco from 1857 to 1859 to help John Brown. She was said to have actively supported his cause with money and work. There was a note from her in his pocket when he was arrested after the Harpers Ferry Armory incident, but as it was only signed with the initials "MEP” (which was misread as "WEP”) she was not caught and

\footnotetext{
${ }^{139}$ San Francisco Examiner, October 13, 1895; January 11, 1904. ${ }^{140}$ Ibid.
} 
was able to return to San Francisco to continue her work there where she was known as the "Black City Hall”. 141

After the war, she publicly changed her racial designation in the City Directory from "White" to "Black", causing a little stir among some whites. She began a series of court battles to fight laws prohibiting blacks from riding trolleys and other such abuses. She usually prevailed.

Pleasant successfully attacked racial discrimination in San Francisco public conveyances when she and two other black women were ejected from a city streetcar in 1866. She sued to win the right for blacks to ride the trolleys and won (Pleasant v. North Beach \& Mission Railway) in $1868 .{ }^{142}$ Her lawsuit, Pleasant v. North Beach \& Mission Railroad Company, outlawed segregation in the city's public conveyances. Her efforts earned her the title "mother of the Civil Rights Movement" in California. Her lawsuit set a precedent in the California Supreme Court and was used in future civil rights cases, such as an 1893 case over segregation in housing. ${ }^{143}$

After Thomas Bell fell to his death from an upper-floor window, suspicions about Pleasant having murdered him arose. These suspicions died down when Bell's will revealed no bequeathing of money or property to her. Troubles arose for Pleasant years later, though, when Bell's widow, whose relationship with Pleasant had deteriorated,

\footnotetext{
${ }^{141}$ Hudson, Lynn M., The Making of "Mammy Pleasant": A Black Entrepreneur in Nineteenth-Century San Francisco, University of Illinois Press; 1st edition, 2002

${ }^{142}$ Crowe, Steve, “Mary Ellen Pleasant: Unsung Heroine”, Crisis, Jan-Feb 1999.

143 Johnson, Jason B., A Day for 'Mother of Civil Rights': Entrepreneur Sued to Desegregate Streetcars in 1860s, San Francisco Chronicle, February 10, 2005, p. B-4.
} 
turned on her and began a legal fight over disposition of the Bell property. Teresa Bell began asserting that Pleasant had pushed her husband out of the window, and her accusations resulted in a barrage of ill feeling toward Pleasant in San Francisco. Part of the reversal in attitude toward Pleasant paralleled the development of San Francisco itself. Racist attitudes returned as the city progressed from a freewheeling frontier town to a more settled society. ${ }^{144}$

In another case that made headlines in the late nineteenth century, Pleasant supported the cause of Sarah Althea Hill's suit against Senator William Sharon of Nevada for breach of a marriage contract. Pleasant provided \$5,000 for Hill's defense against Sharon, supporting the claim that Hill had been Sharon's mistress. Sharon denied the existence of a marriage contract, and although Hill won her suit at the state level, the decision was overturned by a federal judge who claimed that the contract was a forgery.

Mammy Pleasant was the recipient of a number of scandals and smears from 1884-1954. After the court battle between Sarah Althea Hill and William Sharon smeared Mary Ellen badly, the job was finished later when Teresa Bell, Thomas Bell’s widow, sued Mary Ellen over Thomas’ estate. The house Mary Ellen had designed for Thomas Bell and herself became known as the "House of Mystery" and the peculiar

\footnotetext{
${ }^{144}$ San Francisco Examiner, October 13, 1895; January 11, 1904.
} 
arrangements with Thomas' farce of a “marriage” were exposed and paraded through the courts. $^{145}$

The Hill/Sharon battle and Sharon’s newspaper allies, publicly named Mary Ellen as a "Voodoo priestess" (which she may have been) but went on to say that she was a baby stealer, a baby eater, a multiple murderess, a madam, a lying, conniving, cunning, schemer, and maybe, worst of all, hung the epithet of "Mammy" upon her. All the press from the 1880's and beyond was extremely negative to an aging Mary Ellen. She was quoted on more than one occasion as saying, “DON’T call me Mammy!”146

She also built a house, then far out of town, known as the "Geneva Cottage," at the corner of the San Jose road and Geneva (now the corner of Geneva and Bayshore Boulevard near the toxic wasteland of the Southern Pacific rail yards and the Brisbane lagoon), which was the infamous site of numerous wild bacchanalian parties, attended by wealthy San Franciscan men and a bevy of beautiful young women.

The mysterious death of one young woman at the Geneva Cottage led to a consolidation of Mammy's influence as she collected blackmail from the attendees to keep quiet the circumstances of her death. Other associates of Mammy also died mysteriously, often after trying to turn the blackmailing tables on Mammy, but she was never accused, tried, or convicted of any such crime. ${ }^{147}$

\footnotetext{
${ }^{145}$ Hudson, Lynn M., The Making of "Mammy Pleasant": A Black Entrepreneur in Nineteenth-Century San Francisco, University of Illinois Press; 1st edition, 2002.

${ }^{146}$ San Francisco Examiner, October 13, 1895; January 11, 1904.

147 Ibid.
} 
Her lust for power was pursued through several primary techniques: she continued to sponsor runaway slaves as hundreds arrived in San Francisco thanks to her aid. These people she placed in businesses and homes of the city, and they became her ears on the town. She sponsored and housed a number of young women, many of whom continued to follow her wishes for years. She spent a lot of her large fortune on the poor and destitute, earning considerable good will and power. She also used her position as madame to gain control through blackmail over many of the richest men in San Francisco, even helping them dispose of various children their dalliances gave rise to. And finally, Mary Ellen "Mammy" Pleasant used her talent with the voodoo religious rites to control her followers through religious terror.

By her death in 1904, Mammy had lost most of her fortune, and a good deal of Thomas Bell's as well. She is buried at Tulocay Cemetery in Napa, California.

Although never convicted of Thomas Bell's murder, Pleasant was forced at age 85 to move out of the Bell estate, despite her assertion that the Bell property really belonged to her. Claiming to be drained financially by her legal entanglements, Pleasant declared bankruptcy in 1899, but the Oakland Tribune estimated that she was worth from $\$ 35,000$ to $\$ 150,000$ at the time. ${ }^{148}$ Litigation involving the Bell estate continued well beyond Pleasant's death in 1904. Despite being lambasted in the press over the Bell affair, Pleasant was deluged by get-well cards and flowers by her fellow San Franciscans when

${ }^{148}$ Oakland Tribune, September 3, 1916. 
she became seriously ill near the end of her life. The San Francisco Examiner reported that "her deeds of charity are as numerous as the grey hairs on her proud old head."149

In 1953, Helen Holdredge, who had inherited Teresa Bell’s diaries, wrote a book that devoted 37 pages to Mary Ellen’s achievements up to 1875 and 250 pages to the scandalous newspaper accounts of the 1880's. She did not index the book nor did she do citations in the text. There is a list of sources in the back, though some of these sources are unavailable to other researchers. ${ }^{150}$

No matter how the world and historians look at Mammy Pleasant, what is clear is that she was a very shrewd woman who rose from modest circumstances to a position of significant impact in certain spheres of San Francisco society. Also well established is her active support of civil rights causes, both as a protector of newly freed blacks and as a promoter of greater rights for blacks in California.

\section{Sanite Dede}

Ironically, Marie LaVeau and Mary Ellen "Mammy" Pleasant were joined in the title of "Voodoo Queen” by another woman - Sanite Dede, a lesserknown voodoo priestess in New Orleans.

Sanite Dede was the first Voodoo Queen in

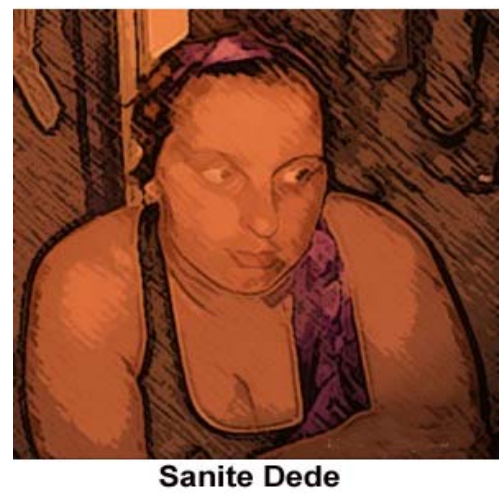

New Orleans in which there is any evidence of. She was brought to New Orleans from

${ }^{149}$ San Francisco Examiner, October 13, 1895; January 11, 1904

${ }^{150}$ Holdredge, Helen, Mammy Pleasant: A San Francisco Scandal. New York City: G. P. Putnam and Sons, 1953. 


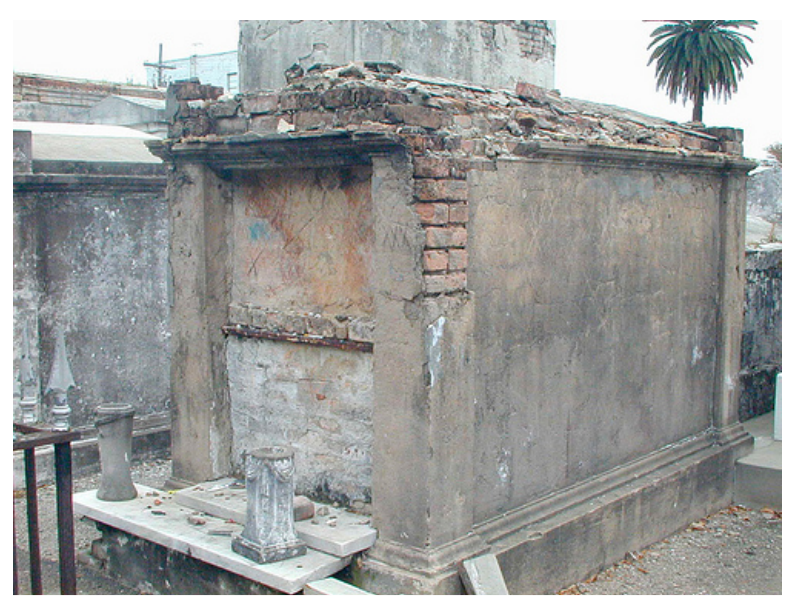

Sanite Dede's Tomb - in St. Louis Cemetery \#2, New Orleans
Santo Damingo and was believed to have purchased her freedom through Voodoo practices. This was most likely due to money made from these secret practices. However, years later she would be seen selling sweetmeats in front of the Cabildo, indicating that she could not have been too financially comfortable if she had to resort to work such as that. She lived at the brickyard on Dumaine Street and was the first person to hold gatherings on the shore of Lake Pontchartrain. Her powers were believed to be at its height in the year 1825. Not much is known about the pre-Laveau Queens of Voodoo or the Voodoo practices under Sanite Dede. ${ }^{151}$ 


\section{CHAPTER 4}

\section{WOMEN OF THE BLACK POWER MOVEMENT}

\section{The Caribbean: Trinidad and Tobago}

"Black Power rage, drama, and style, as revolutionary jargon, offers something to everybody: to the unemployed, the idealistic, the dropout, the communist, the politically frustrated, the anarchist, the angry student returning from humiliations abroad, the racialist, the old-fashioned black preacher who has for years said at street corners that after Israel it was to be the turn of Africa. Black Power means Cuba and China; it also means clearing the Chinese and the Jews and the tourists out of Jamaica.”152

In the 1970's much history was made in Trinidad and Tobago, as in the world over. This was a time when tensions peaked once more after earlier struggles to relieve Black people from the physical bondage of slavery and after two world wars, which had left an indelible impact on the world's people. In fact, Trinidad and Tobago was granted Independence just eight years before in 1962. However, this appeared to be Independence in name only as Trinidadians and Tobagonians were dependent on white capitalists and imperial powers such as the United States, Canada and Britain for their sustenance.

In his article, Black Power in the Caribbean, William R. Lux wrote that the Caribbean is composed of manufactured societies, labor camps, creations of empire. The educational system - that great perpetrator of the status quo-was designed to produce in the areas under or formerly under English colonial rule little black Englishmen steeped in

\footnotetext{
${ }^{152}$ Naipaul, V. S., (Trinidadian novelist), (1970) "Power to the Caribbean people." New York Rev., September: 32-34; (1970:33).
} 
English tradition and history. (Comparable and equally reprehensible is the teaching of the history of white America to black children today in the deep South and presenting it as their history.) The Prime Minister of Guyana, a product of the English system, stated (Burnham, 1970a):

When we were younger we remember being told about Henry V attacking at Agincourt and saying something about St. George. That was part of our education. Our own history was neglected, if not vilified. In fact, some of those who instructed us made a point, sometimes subtly, sometimes clumsily, of establishing to us that we had no history (Lux, p. 208).

Never American, no longer Spanish, English, or French, of largely African (but also East Indian and Chinese) origin, the Caribbean is now suddenly compelled to define itself. And Black Power and its Africanness is the driving force behind the Caribbean's search for its identity. ${ }^{153}$

Those who had recognized such inequities sought to address them under the banner of 'Black Power'. This revolution was characterized mainly by large group protests, boycotts, a few shootings and the occasional throwing of 'Molotov cocktails.' Those who benefitted from capitalism, neo-imperialism and (particularly white) male domination determined that protest actions by the masses were "disturbances" to the order or rather the disorder and diseqilibrium of capitalist society. Thus, the term "disturbances" only derived negative connotations, and was used to describe the positive actions initiated by the revolutionaries. The term "disturbances" indicated all activities

\footnotetext{
${ }^{153}$ Lux, William R., Black Power in the Caribbean, Journal of Black Studies, Vol. 3, No. 2. (Dec., 1972), pp. 207-225.
} 
and ideologies which interfered with the inadequate running of the country by the PNM or negatively impacted corrupt businesses and exploitative socio-economic regimes. It should be noted that not all "disturbances" were products of the black power struggle. Others followed the precedent set by Black Power activism in order to manifest change within their own realms of discontent. ${ }^{154}$

The Black Power leaders attempted to challenge the status quo by demanding reform that would have been beneficial to the masses of the country, but were unsuccessful to a significant degree as the social, economic and political orders remained largely unchanged. The Movement had some effect, notably in the schism that erupted in the PNM (People National Movement) administration, and the nationalization of some industries in the twin island-state. Feminist activism was also an important part of the socalled disturbances of the 1970s. I will address the focal aims of the black power and feminist rebellions, the ways in which activists set out to achieve these aims and the extent of influence the movement had on the authorities. ${ }^{155}$

Also, during the 1970s, capitalism reigned supreme as it is in the present,. The racist economic institution was such that the whites were at the crest of the hierarchical pyramid and blacks were at the base. According to D. Sinclair Da Breo, foreign capitalists dominated the Trinidad economy, "psychologically and financially" indicating the extent to which the institution affected the lives of Trinidadians and Tobagonians.

\footnotetext{
${ }^{154}$ Leslie, 'Disturbances' of the 1970s, Triniview.com, June 13, 2005;

${ }^{155}$ Ibid.

http://www.triniview.com/articles/13062005.html
} 
Unemployment, a major feature of capitalism, was rampant. This underclass, as Marx referred to them, was necessary so that the employers could continue to exploit their workers. Thus, workforces throughout Trinidad and Tobago were paid much less than the actual value of their labor. ${ }^{156}$

The situation of exploitation in Trinidad and Tobago is a legacy of slavery in that material wealth, or lack thereof, was inherently linked to one's race and the color of one's skin. In fact, the OWTU reconfirmed this viewpoint that there is an intricate link between race and class in Trinidad and Tobago and that, "...the call for Black power is the call for proletarian power." The NJAC (National Joint Action Committee) pointed to a 1970 survey,

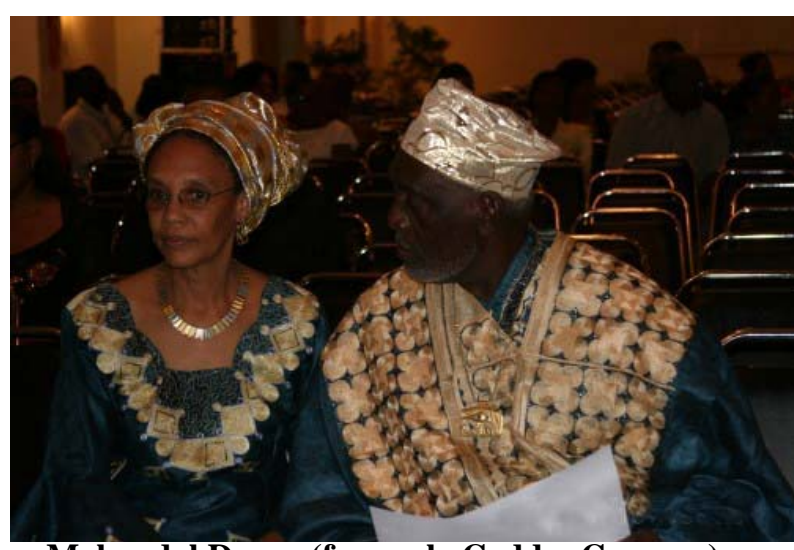

Makandal Daaga (formerly Geddes Granger)

which found that 86 percent of businesses were owned and run by whites. This AngloSaxonism, or rather, utilizing the term coined in the struggle, "Afro-Saxonism" displayed by the PNM regime would no longer be tolerated. The Black Power Movement set out to address these issues of unemployment, underemployment and worker exploitation. Some Black Power activists called for the absolute abolition of capitalism. Others wanted a simple reversal of the power dynamics of the system, rather than its total rejection. Black

\footnotetext{
${ }^{156}$ Da Breo, D. Sinclair, “The West Indies Today: A Thesis on the Forces, Struggles, Frustrations and Peoples of the West Indies”. (Bridgetown: privately published, Letchworth P) 117 pages pb, frontis, 1971). Politics. Caribbean area. A political and economic study. $\underline{\text { Com, Gos. }}$
} 
Power to them was a call for the masses to "...control the heights of the economy...under the ideological slogan of black power." These attempts to change aspects of the system such as blatant racism, was a major challenge to the status quo evident not only in Trinidad and Tobago, but across the globe.

Another challenge to the white and near-white authorities was the attempt to reclaim their African identity. African names were replaced with European ones, African religions went underground in order to survive, African dress was replaced by European and American wear, and African kinky hair was either pressed out with an iron comb or straightened out by chemical processes. Black Power activism was a call to abandon white cultural and aesthetic standards in favor of one’s fitting for Black people and involved the attempted recovery for African cultural uniqueness.

Black women in Trinidad had promoted the cause of the Black men who dominated the Black Power movement. As a result they began to question their own subordination as women and as Africans. Thus, the rise of feminism, which was a direct challenge to male authority, grew out of the Black struggle. Organizations such as NJAC failed to deal with women's issues and believed that a woman's place was beside the man, which served to entrench existing gender relations. 


\section{Dr. Rita Pemberton Interview}

During my interview with Dr. Rita Pemberton in May 2008, she expressed that many people felt the women who followed the men during the Black Power movement weren't doing so because of what the movement stood for, but because they were younger women, the men were older, and it was attractive to follow these older men around. ${ }^{157}$ Dr. Pemberton encouraged me to ask the question (when interviewing others about women and the Black Power Movement in Trinidad and Tobago) as to whether the women who were involved in the Black Power Movement really understood what it was about.

\section{Professor Rhoda Reddock Interview}

The interview with Professor Rhoda Reddock brought another outlook on the women’s role in the Black Power Movement.

Although the feminist struggle was not as visible as the Black Power movement, it was just as important and had lasting implications for women today. In fact, in her article, The Black Power Movement in Trinidad: An Exploration of Gender and Cultural Changes and the Development of a Feminist Consciousness, Victoria Pasley points to the existence of female guerillas in Trinidad during the 1970s that, “...encouraged a subtle challenge to the gender system.”158 Feminist activists had followed in the footsteps of the

\footnotetext{
${ }^{157}$ Washington, Clare, “Interview with Dr. Rita Pemberton, University of the West Indies, St. Augustine, Trinidad and Tobago, W.I, May, 2008.

${ }^{158}$ Pasley, Victoria, "Gender, Race, and Class in Urban Trinidad: Representations in the Construction and Maintenance of the Gender Order, 1950-1980." Unpublished Ph.D. Dissertation, University of Houston, May 1999.
} 
heroine Angela Davis, the self-proclaimed, "black woman communist” and used her example to lure women to join the movement in Trinidad and Tobago.

\section{Kafra Kambon}

(The women who were part of the Black Power Movement in Trinidad \& Tobago during the 1970s)

"In the beginning, it may have appeared the younger women or young girls were caught up in the Black Power movement here, because they were attracted to the older men. But it may have also been because the "Movement" was something different for the younger generation-men and women." "Th9 That was how Kafra Kambon explained it to me during my interview with him in Trinidad and Tobago on

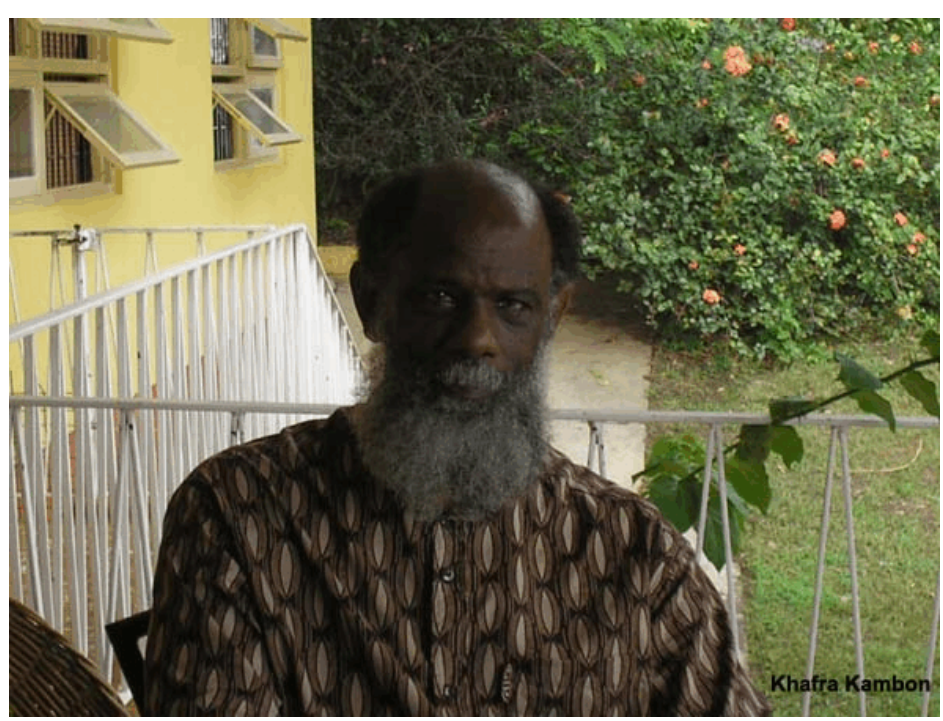
July 6, 2008. Mr. Kambon went on to explain that while these may have been the initial motives for women to be part of the Black Power movement, that notion changed as women began to think of their own rights—as women.

"Did these women know what the movement was really about? Sure they did," Kambon continued. "In fact, some of the women were worse than the men."

\footnotetext{
${ }^{159}$ Washington, Clare, “Interview with Kafra Kambon”, Trinidad and Tobago, W.I., July 6, 2008.
} 
Kafra Kambon can attest to the events, as he was a key member in the movement along with Makandal Daaga. He reiterated how some of the women had found themselves on "The Most Wanted" lists by different law enforcement organizations.

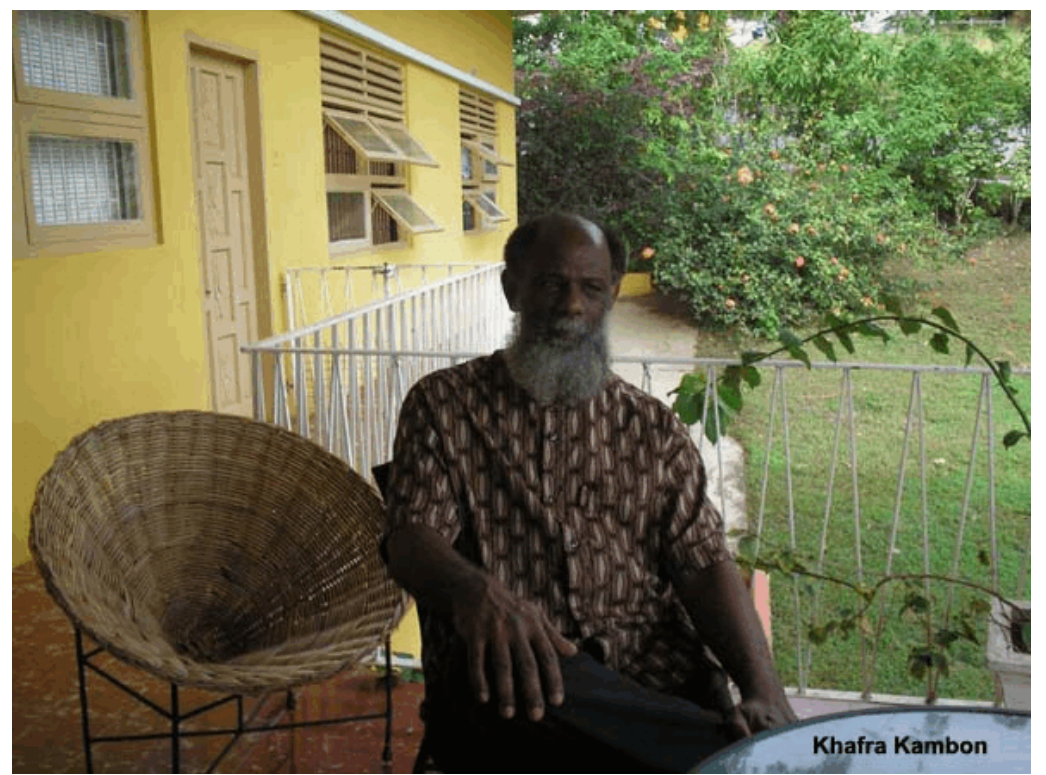

Kambon rattled off a number of women names, and spoke about the role each one of them played in the movementincluding his wife, who was not present at the time of the interview.

According to him, many of the women's homes were basically secret hideouts for those who were the “Most Wanted”, and they weren’t afraid at all of having their homes used as sanctuaries, in spite of the fact they knew they were being watched. He also spoke about how they women in Trinidad and Tobago had role models in the U.S. such as Angela Davis, Kathleen Cleaver, and Assata Shukur. 


\section{CHAPTER 5}

\section{WOMEN OF AFRICAN TOWN, ALABAMA}

“In July 1860, the schooner Clotilda carried to Mobile, Alabama, the last African slaves imported into the United States. Sylviane Diouf carefully reconstructs the experiences of the 110 captives from their origins in Dahomey to their life on the outskirts of Mobile in her book, Dreams of Africa in Alabama: The Slave Ship Clotilda and the Story of the Last Africans Brought to America. Half were women. Half were under fifteen years old. Through an impressive study combining a historian's analysis of archival and published sources with an anthropologist's fieldwork in Africa and Alabama, Diouf provides a narrative of the Clotilda Africans and an insightful discourse on race within the United States. ${ }^{160}$ They spoke their native language and carried on their tribal traditions into the 1950s.

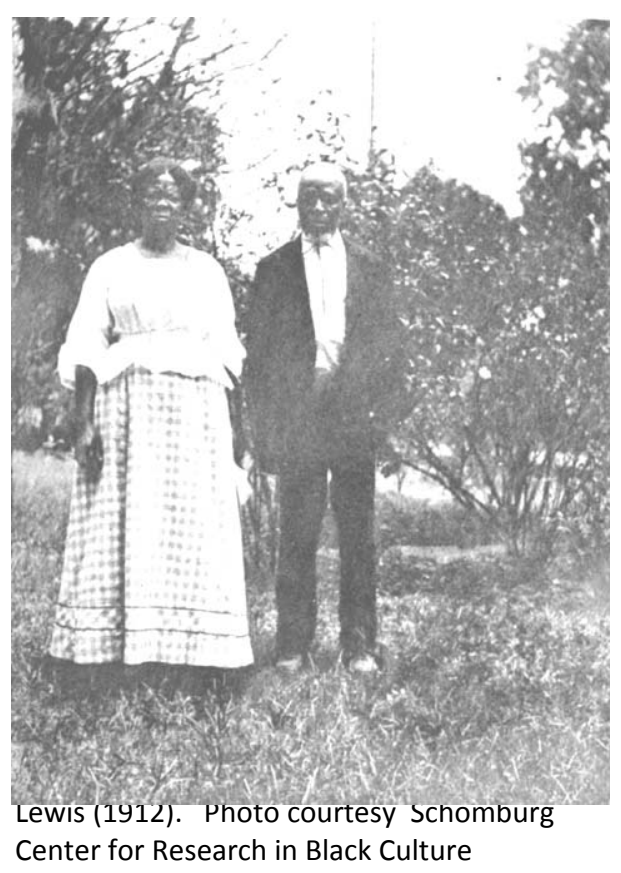

\footnotetext{
${ }^{160}$ Sylviane A. Diouf. Dreams of Africa in Alabama: The Story of the Clotilda and the Last Enslaved Africans Brought
} 


\section{Cudjo and Abache}

Some voyages left directly from the United States. The Clotilda sailed from Mobile, Alabama in March 1860 and landed in Whydah (Benin) in May. The ship, with 110 men, women, and children on board arrived back in Mobile on July 8. Cudjo Lewis and Abache (Clara Turner), both Yoruba, were part of the group.

We have to remember that theirs is not ancient history. Cudjo, the last survivor of the last slave ship died in 1935 and the last African Americans born in slavery passed away in the 1950s.

Each time we recall their immense suffering and exploitation; we should also celebrate Cudjo, Clara, Zuma and the others' resilience and bravery and measure the progress that theirs and their descendants' fighting spirit made possible. Three days after Cudjo Lewis’ funeral in 1935, Fraser Robinson III was born in Chicago. His daughter Michelle is the First Lady of the United States.

to America. Oxford: Oxford University Press, 2007. 


\section{CHAPTER 6}

\section{OTHER LESSER-KNOWN WOMEN}

\section{Remember the Ordinary Heroes (USA)}

\section{Mary Fields (c 1812 - 1914) - Cascade, Montana (aka "Stagecoach Mary")}

(Phtographs courtesy Sister Mary Rose Krupp, Ursuline Convent Offices, 4045 Indian Rd., Toledo, OH 43606. Used with permission.)

When people hear of cowboys or pioneers, they usually think of tough, brave

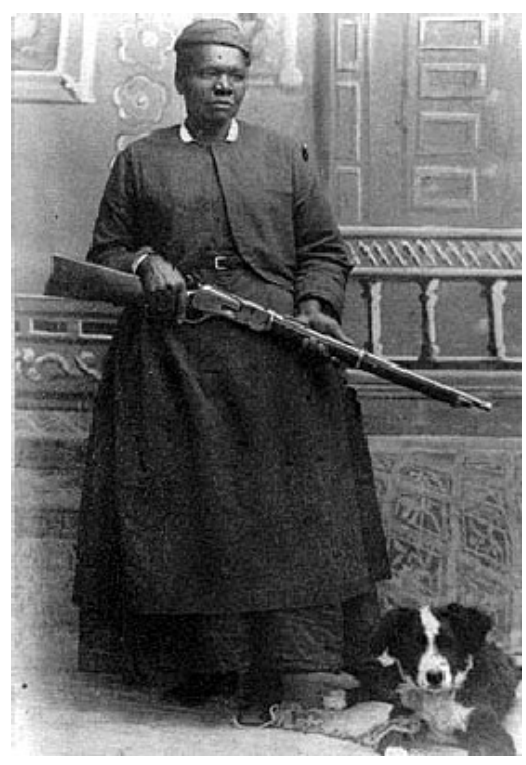

men. However, there were also many women pioneers who paved the way west. Among the best known is “Stagecoach Mary” Fields.

Born sometime around 1812, Mary began life as a slave in Hickman County, Tennessee. Few facts, however, are known about her early years. According to some historians, she was owned by Judge Dunn and grew up on his family farm. She became friends with his

daughter, Dolly, who was around the same age. ${ }^{161}$

Unlike most other African Americans of the time, Mary was taught to read and write. After the Civil War and the emancipation of slaves, many ex-slaves left the

\footnotetext{
${ }^{161}$ Drewry, Jennifer M., Mary Fields a Pioneer in Cascade’s Past, Footsteps Magazine, Peterborough, NH, March/April 1999.
} 
plantations and farms of their former owners. Mary, however, stayed with the Dunns. When she did leave, she spent time in Ohio and along the Mississippi River. ${ }^{162}$

According to some reports, when Mary was around 30 years old, she received a letter from Dolly, who had become a nun and was now known as Sister Am adeus. Mary welcomed her friend's request to join her at the convent. Soon after Mary’s arrival, however, Sister Amadeus headed west to become the headmistress of a school for Native American girls in Montana. For some reason, Mary chose not to accompany her friend. Only when she learned that Sister Amadeus was ill with pneumonia did Mary head west to Montana. Mary must have liked the area. After she had helped nurse her friend back to health, she decided to stay.

The school, called Saint Peter's Mission, consisted of old buildings that were badly in need of repair. Mary, who stood over six feet tall, was as strong as any man and very good at fixing anything. She soon became the foreman, or boss, of the other workers at the school. There was one man, however, who did not want

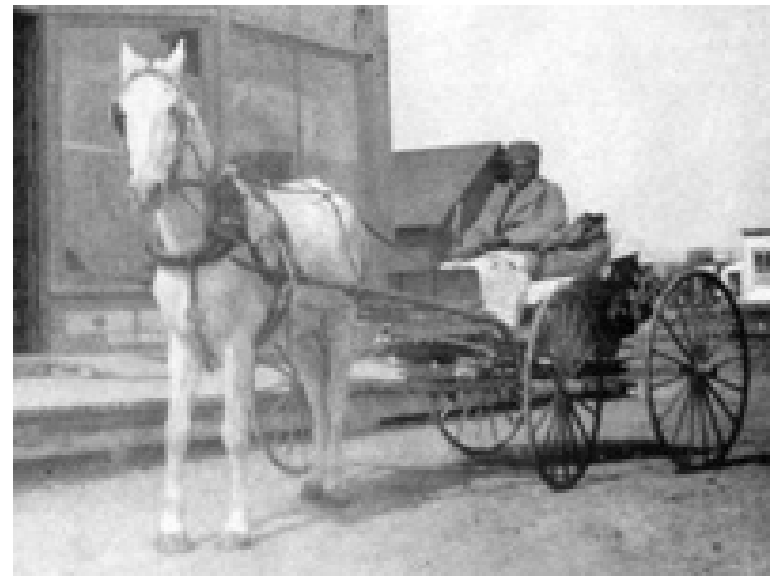
to take orders from a black woman. He argued with Mary, and then struck her. While Mary was falling, the man reached for his gun. Mary, in self-defense, snatched her six-

\footnotetext{
${ }^{162}$ Miller, Robert, The Story of Stagecoach Mary Fields, Silver Burdett Press, 1995; Article in Ebony 32 (October 1977), pp.96-98
} 
shooter and fired. She was as fast with a pistol as any man. When the bishop in charge of the school heard about the gunfight, he demanded that Mary be fired. Sister Amadeus could not bear to let her friend go under such circumstances. ${ }^{163}$

When Mary heard that the United States Postal Service was looking for someone to deliver mail from the town of Cascade, Montana to families in the surrounding areas, she applied for the job. Even though she was about 60 years old at the time, Mary proved herself the fastest applicant to hitch a team of six horses and was hired. Thus, Mary became the second woman and the first African American woman to work for the United States Postal Service.

Mary drove the mail stagecoach along the trails that linked Cascade to the remote homesteads. One of her stops was Saint Peter's, which was located 17 miles from Cascade. Mary loved the job, despite the many dangers and difficulties. Thieves and wolves roamed the countryside, always ready to pounce on prey.

In the winter, heavy snowfalls plunged the trails under drifts. On several occasions, Mary’s horses could not cross the drifts. Determined to do her job, she left the horses behind and walked alone to deliver the mail. Once she walked 10 miles back to the depot.

Mary continued to deliver the mail until she was almost 70 years old, earning the nickname of "Stagecoach Mary." Then she decided to "slow down." the nuns at the

\footnotetext{
${ }^{163}$ Drewry, Jennifer M., Mary Fields a Pioneer in Cascade's Past, Footsteps Magazine, Peterborough, NH, March/April 1999.
} 
mission helped her open a laundry service in Cascade. A laundry business, however, was not enough to keep Mary busy and she spent much time caring for her garden.

The town so loved and respected Mary that on her birthday they even closed the schools to celebrate the occasion. She was well over 80 years old when the townspeople laid her to rest at the foot of the mountain trail that led to Saint Peter's Mission.

In 1914 she died of a failure of her liver. Neighbors buried her in the Hillside Cemetery in Cascade, marking the spot with a simple wooden cross which may still exist today.

“Stagecoach Mary” Fields broke all boundaries of race, gender and age. She was a true pioneer.

Minnie M. Geddings Cox (1869 - 1933)

While doing something for leisure, I decided to try finding out who were some of

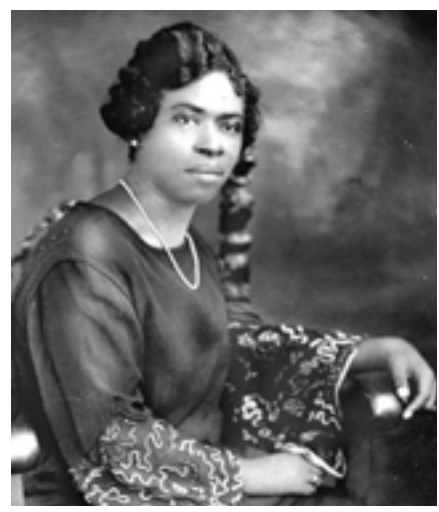
the prominent/famous or less prominent (more obscure or lesser known) women who were born in the same month and date (February 5th) as I was. One of the women I found was Minnie Cox, who I'd never heard of or read about before. She was born on February 5, 1869. Presently, her date of death is unknown. She was an African-American teacher, and postal administrator.

Minnie M. Geddings Cox was one of two daughters born to William and Mary Geddings of Lexington, Mississippi. She graduated from Fisk University and first taught 
school at the common schools in Lexington. Soon after married and assisted her husband, Wayne, when he was principal of the Indianola Colored Public School. In 1891, President Benjamin Harrison appointed Cox postmistress of Indianola, and was reappointed by President William McKinley; becoming first Black postmistress of the United States.

On January 25, 1900, McKinley raised her rank from fourth class to third class and appointed Mrs. Cox for a full four-year term. However, in the fall of 1902 under the presidency of Theodore Roosevelt a controversy brought national attention to Mrs. Cox. Jim Crow Laws overran Reconstruction in America and whites wanted Blacks eliminated from leadership positions. Some of the local whites in Indianola met and drew up a petition requesting Cox's resignation. Increased tension and threats of physical harm caused Cox to submit her resignation to take effect January 1, 1903.

Roosevelt felt Mrs. Cox had been wronged, and that the authority of the federal government was being compromised and refused to accept her resignation. Instead, he closed Indianola's post office on January 2, 1903, rerouted the mail to Greenville, MS, and Cox continued to receive her salary. Also for four hours in January 1903, the Indianola postal event was debated on the floor of the United States Senate, and appeared on the front pages of newspapers across the country. A year later, at the expiration of Mrs. Cox’s term, in February 1904 the post office was reopened, but demoted in rank. ${ }^{164}$

\footnotetext{
${ }^{164}$ Reference: New York Post , 1211 Avenue of the Americas , New York, NY 10036-8790; The African American Registry ${ }^{\circledR}$, a resource on African American History, is a 501(c) (3) non-profit education organization The African American Registry ${ }^{\circledR}$ Copyright 2005, 2006.
} 
Dorothy Height (1921 - 2010)

\section{(Godmother of the Civil Rights Movement)}

Dorothy Height, began her civil rights work in the 1930s. She was also the chair and president emeritus of the National Council of Negro Women, and someone whom President Obama called "the godmother of the Civil Rights Movement”. Dorothy Height died of natural causes on April

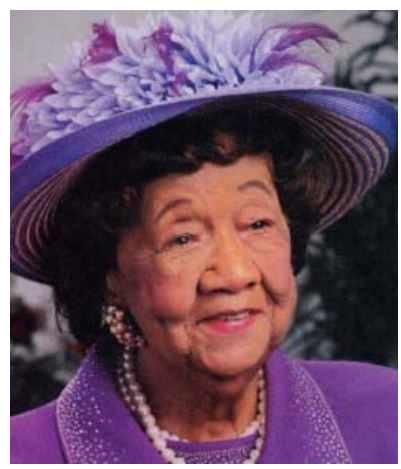
20, 2010 at the age of 98 years old. She was one of the great activist black women that younger sisters looked to, as a model of grace and strength combined. She was remembered by many people as a pioneering voice of the civil rights movement whose life's work and activism stretched from the New Deal through the 2008 election of President Obama.

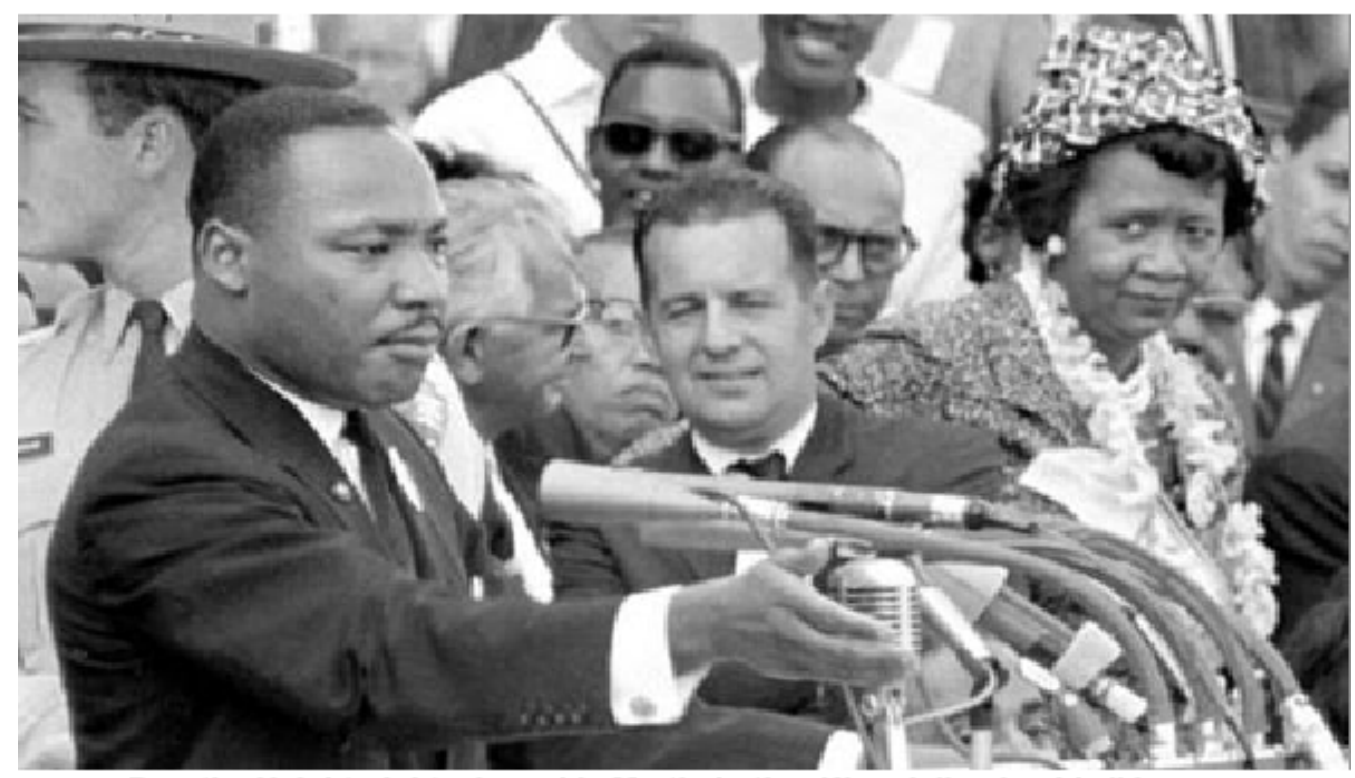

Dorothy Height, right, alongside Martin Luther King delivering his 'I have a dream' speech at the Lincoln Memorial in 1963. Photograph Courtesy: AP 


\title{
Remember the Ordinary Heroes (Nigeria)
}

\author{
Aba Rebellion of 1929 (or The War of the Women) - Nigeria ${ }^{165}$ \\ Madam Mary Okezie (1906-1999)
}

Madam Mary Okezie was the first Ngwa woman to gain Western education, and was teaching at the Anglican Mission School in Umuocham Aba in 1929 when the women's revolt broke out. Although she did not participate in the revolt, Madam Okezie

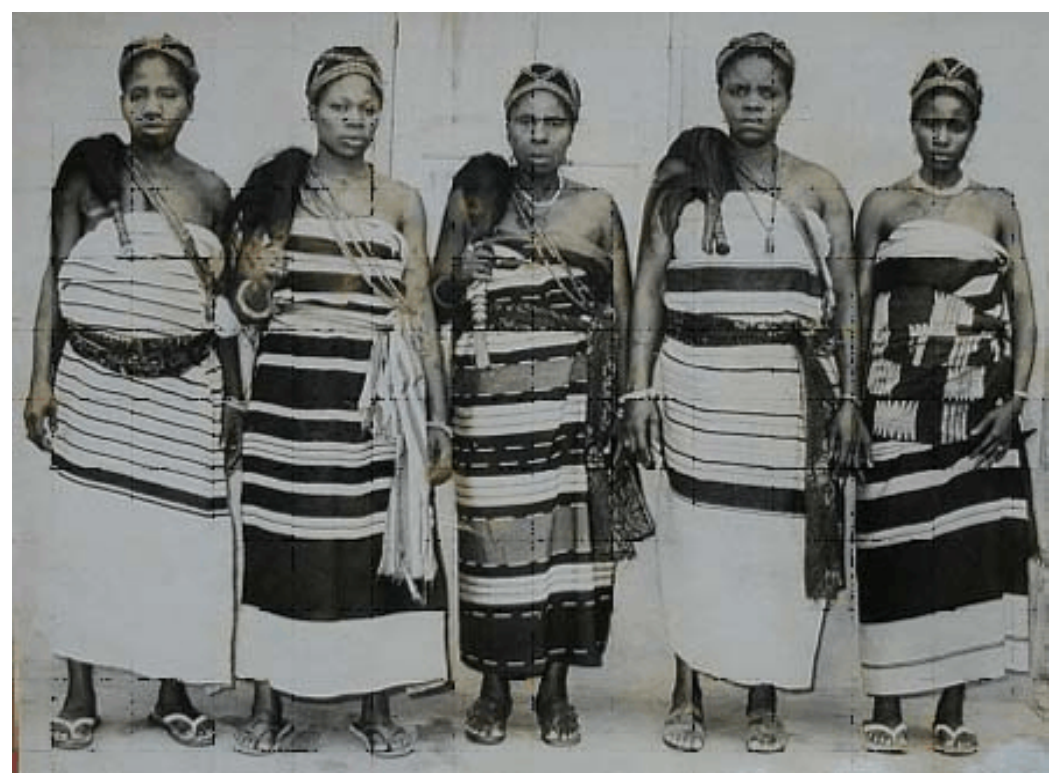
was very sympathetic to the women's cause. She was the only woman who submitted a memo of grievance to Aba Commission of Inquiry (sent in 1930). ${ }^{166}$ Today, the major primary source for studying the revolt is the Report of the Aba Commission of Inquiry. After the revolt, Madam Okezie emerged as a leader of Ngwa women, founding the Ngwa Women's Association, and working for her entire life to support women's rights in Nigeria. ${ }^{167}$

\footnotetext{
${ }^{165}$ Wikipedia Contributors. "Igbo Women's War." Wikipedia, The Free Encyclopedia. Wikipedia, The Free Encyclopedia, 6 Nov. 2009. Web. 9 Apr. 2010.

${ }^{167}$ Martin, Susan M. (1988). Palm Oil and Protest: An Economic History of the Ngwa Region, South-Eastern Nigeria, 1800-1980. New York: Cambridge University Press.
} 
The Women's revolt of 1929 was sparked by a dispute between a woman named Nwanyeruwa and a man, Mark Emereuwa, who was helping to make a census of the people living in the town controlled by the Warrant, Okugo. Nwanyeruwa was of Ngwa ancestry, and had been married in the town of Oloko. In Oloko, census was related to taxation, and women in the area were worried about who would tax them, especially during the period of hyperinflation in the late 1920s.

On the morning of November 18, Emeruwa arrived at Nwanyereuwa's house, and approached Nwanyereuwa, since her husband Ojim had already died. He told the widow to "count her goats, sheep and people." Since Nwanyereuwa understood this to mean, "How many of these things do you have so we can tax you based on them", she was angry. She replied by saying "Was your widowed mother counted?," meaning "that women don't pay tax in traditional Igbo society."168 The two exchanged angry words, and Nwanyeruwa went to the town square to discuss the incident with other women who happened to be holding a meeting to discuss the issue of taxation of women. Believing they would be taxed, based on Nwanyeruwa's account, the Oloko women invited women (by sending leaves of palm-oil trees) from other areas in the Bende District, as well as from Umuahia, Ngwa and elsewhere. They soon gathered nearly 10,000 women who protested at the office of Warrant Chief Okugo, demanding his resignation and calling for a trial. $^{169}$

\footnotetext{
${ }^{168}$ Aborisade, Oladimeji, Mundt, Robert J,. Politics in Nigeria. Longhorn, New York, United States, 2002.

169 Oriji, John N., Igbo Women From 1929-1960. West Africa Review: 2 , 1., 2000.
} 
The leaders of the protest in Oloko are known as the Oloko Trio, consisting of women named Ikonnia, Mwannedia and Nwugo. The three were known for their skills in speaking, their intelligence, and their passion. When protests became tense, it was often these three who were able to de-escalate the situation, preventing violence. However, after two women were killed while blocking colonial roads as a form of protest, the trio was not able to calm the situation there, and the police and army were sent to the town. ${ }^{170}$

Nwanyereuwa played a major role in keeping the protests non-violent. She was advanced in age compared to many of the youth who led the protests, and under her advice, the women protested in song and dance, "sitting" on the Warrant Chiefs until they surrendered their insignia of office and resigned. As the revolts spread, other groups followed this pattern, making the women's war a peaceful one. Other groups came to Nwanyeruwa to get in writing the inspirational results of the protests, which, as Nwanyeruwa saw them, were that, "women will not pay tax till the world ends.[and] Chiefs were not to exist anymore."

A major tactic in the protests was what is known as "sitting". Along with singing and dancing around the houses and offices of the Warrant Chiefs, the women would follow their every move, invading their space and forcing the men to pay attention. The wives of the Warrant Chiefs were often disturbed and they too put pressure on the Warrants to listen to the demands of the women. This tactic of "sitting on the Warrants",

\footnotetext{
${ }^{170}$ Afigbo, Adiele E., The Warrant Chiefs: Indirect Rule in Southeastern Nigeria, 1891-1929. Humanity Press, 1972.

${ }^{171}$ Leith-Ross, Sylvia, African Women: A Study of the Ibo of Nigeria. London: Faber and Faber, 1939; Reprint, New York: Praeger, 1965.
} 
(i.e. following them everywhere and anywhere), was very popular with the women in Nigeria, and used to great effect.

As a result of the protests, the position of women in society was greatly improved. In some areas, women were able to replace the Warrant Chiefs. Women were also appointed to serve on the Native Courts. After the Women's war, women's movements were very strong in Ngwaland, and many events of the 1930s, 1940s, and 1950s were inspired by the Women's War, including the Tax Protests of 1938, the Oil Mill Protests of the 1940s in Owerri and Calabar Provinces, and the Tax Revolt in Aba and Onitsha in $1956^{172}$. On two occasions were British district officers called and security forces forced to break up protests. During these occasions, at least 50 women were shot dead and 50 more were wounded. The women themselves never seriously injured anybody against who they were protesting, nor any of the security forces who broke up those protests. ${ }^{173}$

\section{Other Major Figures in the Women's War}

These women also played major roles in the Aba Rebellion or the Women's War: Mary of Ogu Ndem (Mary of the Women's War); Ihejilemebi Ibe of Umuokirika Village; and Ahebi Ugabe of Enugu-Ezike: "The Female Leopard" who was appointed as a Native Court Member in 1930.

${ }^{172}$ Wikipedia contributors. "Igbo Women's War." Wikipedia, The Free Encyclopedia. Wikipedia, The Free Encyclopedia, 6 Nov. 2009. Web. 9 Apr. 2010.

${ }^{173}$ Ibid. 
The fact that this protest was organized by African women in times of European male colonial domination of the territory called Nigeria - is considered a credit to the courage and diligence it took to ensure their imprints on the pages of history.

\section{Remember the Ordinary Heroes (Caribbean)}

\section{The Butterflies (The Mirabal Sisters) - Cuba}

During the last days of the Trujillo dictatorship in the Dominican Republic, three

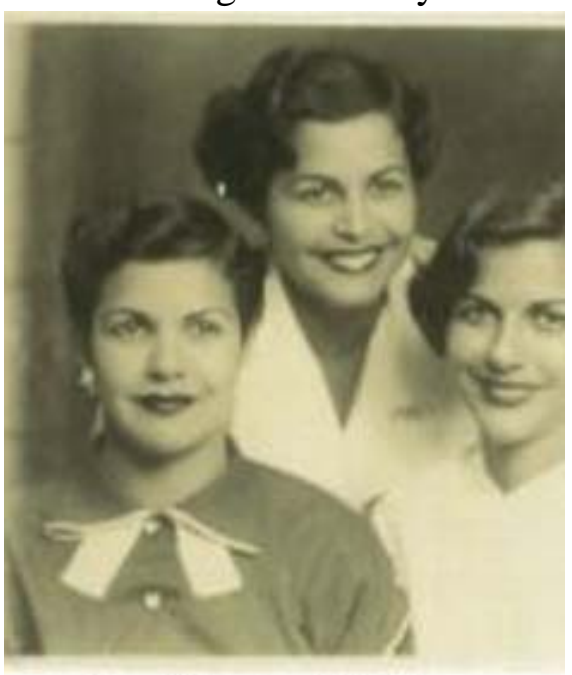

The Mirabal Sisters young women, members of a conservative, pious

Catholic family, who had become committed to the revolutionary overthrow of the regime, were ambushed and assassinated as they drove back from visiting their jailed husbands. Thus martyred, the Mirabal sisters have become mythical figures in their country, where they are known as las mariposas (the butterflies), from their underground code names. ${ }^{174}$

Museum of the Mirabel Sisters. The Mirabel sisters were extremely influential in the rebellion against Trujillo. Trujillo was assassinated shortly after they were. They were killed on their way home from visiting their husbands in prison in Puerto Plata and then put

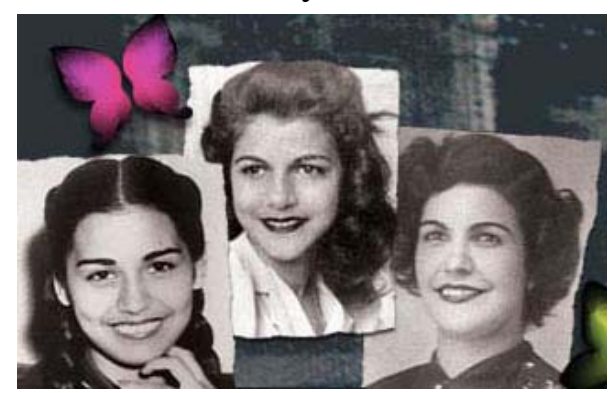

${ }^{174}$ Alvarez, Julia, In the Time of the Butterflies, Plume, 1995. 
in their car and it was staged to look like an accident, but everyone knew they had been assassinated and did not die in a car crash. They are buried on the grounds of the museum along with Minerva's husband Manolo. The museum is at the house where the sisters lived the last 10 months of their life. Inside, it is set up with their furniture and their clothes are still in the closet. There is a display of things that were in their car when they were found dead

\section{Dede Mirabal}

Dede Mirabal is the second-born of the four sisters. She never became actively involved in the underground. She supported her sisters' ideas, but did not think it was

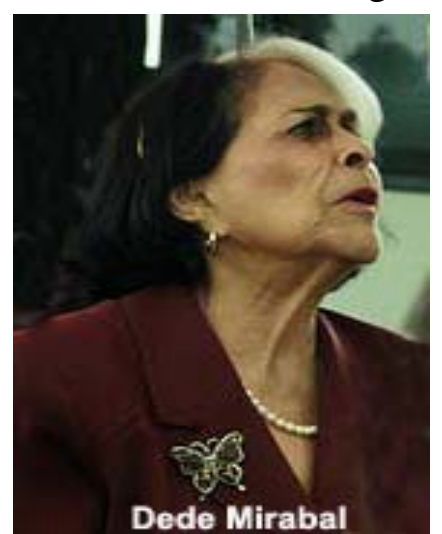
wise to be so bold. She married Jaime Fernandez and they lived close to the house where she grew up. Jaime was also instrumental in her decision to refrain from rising against Trujillo. Dede survived her sisters and is alive today. She and her mother helped to raise Patria, Minerva, and Mate's children. Dede still lives in the house where they grew up and we went there after we left the museum. The gardens at both houses were gorgeous, and she runs the Museum of the Mirabel Sisters. 


\section{CONCLUSION}

During my research for the Fulbright grant project and this thesis, I discovered a lot of brave and lesser-known heroines both before and after the period of enslavement. These are some of the women, who in the past, did much but have received little in the way of historical recognition. The list is much longer than what I've included here in my thesis --from the Caribbean and the USA. A series of interviews during my grant period were conducted in Trinidad and Tobago. My short stay in Santo Domingo, Dominican Republic and San Juan, Puerto Rico was an attempt to not only learn more about the women of the past in those areas, but to familiarize myself with those who are still alive and continuing to fight for justice and equality, such as Rhoda Reddock and Hazel Brown in Trinidad and Tobago, and Antoinette Harrell along with her Gathering of Hearts organization in the Mississippi Delta and New Orleans areas of the U.S.

Of all the states in the USA, my study found the African American women in Texas to be very strong-willed while enslaved and after being emancipated - very much like their sisters in the Caribbean. It would have been very easy to devote two or three chapter to Black Texas women and resistance, alone. Their spirit of resistance and strength has carried forward through generations of strong-willed Texas women. One such woman is former Senator Barbara Jordan. She became very active during the Civil Rights movement in the 1960s. Many saw the 1960'sas a period of transition and hope in American history. With the election of the first Catholic president, John F. Kennedy, and 
the epic changes brought on by the Civil Rights movement, it was a time of change. Jordan was determined to be part of that change. After becoming the speaker for the Harris County Democratic Party, she ran for the Texas House of Representatives in 1962 and 1964. She lost on both occasions. Undeterred, Jordan ran for a third time in the newly reapportioned Harris County (Texas). She who was the first African American elected to the Texas Senate since Reconstruction in 1883, and the first woman ever to hold the position. She then went on to become a member of the U.S. House of Representatives. In 1984, Jordan was voted "Best Living Orator" and elected to the Texas Women's Hall of Fame.

\section{The Past}

Enslaved women in both the Caribbean and USA have always displayed a high spirit of resistance. This is clearly seen in the select personalities covered here in this thesis. Some of these include but not limited to Nanny of Jamaica (or Nanny of the Maroons); Queen Mary Thomas of 1878 Fireburn Labor Revolt on the island of St. Croix, U.S. Virgin Islands; Queen Anacaona, who held her own against Christopher Columbus and his torture of the indigenous people, until she was betrayed and sentenced to death herself; “Ti Piggi/Piggy” (may have actually been named Mary Jane Thomas) who was identified as the leader of the 1876 Belmanna Riots on the Roxborough Estate in Tobago, West Indies; Queen Coziah Harmon, who led the 1892 Coal Carrier's Strike (or Mexican Silver Riot ), and was able to obtain the desired results for herself and her fellow coal workers through non-violent means, on the island of St. Thomas, U.S.VI; 
Elma Constance Francois, who founded the Negro Welfare Cultural and Social Association (NWCSA) in Trinidad and Tobao, W.I.; Jacqueline Creft, who was one of the leaders of the New Jewell Movement and also the Grenada Revolution; Gene Miles, who stood up against her own, and was one of the major witnesses in the 1965 Gas Station Racket Inquiry in Trinidad and Tobago. In the end, Gene died peacefully of nothing more than a broken heart; the women who bravely fought in the Haitian Revolution alongside the renowned hero of the Haitian Revolution--Toussaint Louverture. Most notable is Suzanne "Sanite” Bélair and Catherine Flon. None of the women who fought and have received the notoriety as the men heroes (Toussaint Louverture, Jean Jacques Dessalines, Henry Christophe, and Alexandre Petion).

\section{The Present}

Today there are still women of spirit, resistance and strength such as Professor Rhoda Reddock, a member of CAFRA (Caribbean Association for Feminist Research and Action); Ms. Hazel Brown, Coordinator for Network of NGOs of Trinidad \& Tobago for the Advancement of Women (T\&T Network); Dr. Rita Pemberton, Head of the History Department, University of the West Indies, St. Augustine; and Ms. Antoinette Harrell, who continues the efforts of Dr. Martin Luther King, Jr. in the poverty-stricken areas of the Mississippi Delta areas, as the Co-founder of Gathering of Hearts. These strong women, as well as many others do not waver in their dedication to forge ahead and guarantee equality, freedom, and the education of all women. They all exemplify the 
fighting spirit of their foremothers in both the Caribbean and USA, through means of education (gender issues awareness) and political activism.

No greater spirit of resistance can be found as that in Mae Wall Miller, who along with her entire family endured the bonds of slavery that should have ended not in 1962 as it did, but with the signing of the U.S. Declaration of Independence in the 1865, giving freedom to all slaves. Mae Miller and her family weren’t aware that slavery had ended and that they were "free people", and thus continued to be enslaved - until 1962. Today, with the help of Antoinette Harrell, Mae is a spokesperson for freedom from bondageboth mentally and physically.

\section{The Future}

The future for women and resistance should be much more widespread with women like Antoinette Harrell and Hazel Brown who continue making strides for freedom and equality for all women. Antoinette's tireless efforts to bring to the forefront how women, children and some men are still enslaved and living in unbelievable poverty in the Mississippi Delta region. In teaching my course last summer on Women and 20th

Century Slavery in the U.S., I designed my class around the theme that Antoinette Harrell focuses on - "Those Left Behind”. Basically, after the Declaration of Independence was signed in 1865 giving freedom to the enslaved, not all African Americans living on plantations (especially in the southern portion of the U.S.) knew they were free. These are the ones “left behind”, because the government didn’t agents or anyone out to check 
and investigate as to whether or not indeed, all slaves had been sent free by their previous owners.

As women become more educated and self-sufficient, their stories of resistance and strength will continue to unfold. And history books will have no choice but to reflect these contributions, as women, especially women of the African diaspora stories can no longer be suppressed, glossed over or simply ignored altogether.

In studying women's contributions to history and culture, I find a rich resource of role models and ideas to give me more hope and some cautionary notes for the future of humanity.

The questions that linger in my study include: 1 ). Who are the insurgent intellectuals now?; 2). Do our insurgent intellectuals and activists fill the same role or do they fill different roles now than 20, 40, 60, 100 years ago; and who are the ones carrying on the work of women like Ella Baker, and does their role look the same as it did when Ella filled those shoes, or have the gains of the movement necessitated changes? I would hope that each of us sees ourselves as somehow perpetuating the ideology and work of women who resisted, and yet while I consider myself an activist, I also recognize that, at this point, my life is not as fully devoted to the movement(s) and resistance as were the lives of Ella Baker, Rosa Parks, JoAnn Gibson Robinson, Nanny of Jamaica, Claudette Colvin, Queen Coziah Harmon, Madam Mary Okezie and the Aba Women, the Mirabal Sisters, Mae Wall Miller, Elma Francois and others like them. 


\section{REFERENCES}

Aborisade, Oladimeji, Mundt, Robert J., 2002 Politics in Nigeria. Longhorn, New York, United States.

Academy of Achievement, Rosa Parks Biography http://www.achievement.org/autodoc/page/par0bio-1

Afigbo, Adiele E.

1972 The Warrant Chiefs: Indirect Rule in Southeastern Nigeria, 1891-1929. Humanity Press.

Agorsah, E. Kofi

1992

Archaeology and Maroon Heritage in Jamaica, Jamaica Journal, 24 (2): $2-9$.

1994

Maroon Heritage: Archaeological, Ethnographic and Historical Perspectives, Kingston, Canoe Press: 5 - 8 and 163 - 187.

Aitken, Jonathan

2007

John Newton: From Disgrace to Amazing Grace (London, Continuum $\mathrm{UK})$

Alvarez, Julia

1995 In the Time of the Butterflies, Plume, 1995.

Asson, Cecily

2010 Wrong to Send Girls to Women’s Prison, Trinidad \& Tobago’s Newsday, Daily News Limited, Port-of-Spain, April 2, 2010;

http://www.newsday.co.tt/day/1,40097.html

Beckles, Hilary

1989 "Natural Rebels: "A Social History of Enslaved Black Women in Barbados, Rutgers University Press. New Jersey.

Beckles, Hilary and Shepherd, Verene

1996 Caribbean Freedom: Economy and Society from Emancipation to the Present, Kingston, Ian Randle Publishers. 
Beckles Hilary 1998

Historicizing Slavery in West Indian Feminisms, Feminist Review, No. 59, pp. 34-56; Rethinking Caribbean Difference (Summer, 1998); Palgrave Macmillan Journals.

Beckles, Hilary, An Economic Life of Their Own: Slaves as Commodity Producers and 2003 Distributors in Barbados in Gad J. Heuman and James Walvin, editors, The Slavery Reader, Volume 1, pp. 515-516; Routledge, 2003.

Besson, Gerard and Alice $2001 \quad$ Folklore and Legends of Trinidad \& Tobago, Paria Publ. Co., 2001.

Bibbs, Susheel

$1998 \quad$ Heritage of Power (Marie LaVeau/Mary Ellen Pleasant, MEP Publications; 1st edition, 1998.

Black, Mindie Lazarus

1994 "Slaves, Masters, and Magistrates: Law and the Politics of Resistance in the British Caribbean, 1736-1834," in Contested States Law, Hegemony, and Resistance, Mindie Lazarus Black and Susan F. Hirsch, eds., New York \& London: Routledge, 1994.

Brathwaite, Edward Kamau

$1977 \quad$ Nanny, Sam Sharpe, and the Struggle for People's Liberation, API for the National Heritage Week Committee, Kingston, Jamaica, 1977.

Brereton, Bridget

1984 "Post-Emancipation Protest in the Caribbean: The 'Belmanna Riots' in Tobago, 1876.” Caribbean Quarterly 30, no. 3 \& 4 (1984): 110-123.

Bush, Barabara

1990 Slave Women in Caribbean Society 1650-1838, Kingston, Heinemann Caribbean.

Camp, Stephanie M. H

2004 Closer to Freedom: Enslaved Women and Everyday Resistance in the Plantation South, The University of North Carolina Press.

Campbell, Horace G.

1987

Rasta and Resistance: From Marcus Garvey to Walter Rodney, Trenton, New Jersey: Africa World Press. 
Changekeeper, “Why Am I Not Surprised?: The Art of Re-Enslavement,” July 1,2008, http://whyaminotsurprised.blogspot.com/2008/07/art-of-re-enslavement.html

Chin, Pat; Dunkel, Greg; Flounders, Sarah, and Ives, Kim, comp. and ed.

$2004 \quad H a i t i:$ A Slave Revolution: 200 Years After 1804. New York: International Action Center.

Cobb, William H.

2004 "Commonwealth College.” The Encyclopedia of Arkansas History \& Culture. 21 Oct. 2004.

http://www.encyclopediaofarkansas.net/encyclopedia/entry-detail.aspx?entryID=10

Coleman, Kenneth and Stephen Gurr, Charles, eds.

1983 Dictionary of Georgia Biography, Athens: University of Georgia Press, 1983.

Collins, Patricia H., Black Feminist Thought: Knowledge Consciousness and the Politics 1991 of Empowerment. New York: Routledge

Craton, Michael

1982 Testing the Chains: Resistance to Slavery in the British West Indies, Ithaca, NY: Cornell University Press

Crawford, V., Beyond the Human Self: Grassroots Activists in the Mississippi Civil 1990 Rights Movement. In V. L. Crawford, J. A Rouse, \& B. Woods (Eds.), Women in the Civil Rights Movement: Trailblazers and Torchbearers, 1941-1965. New York: Carlson.

Crowe, Steve

1999 “Mary Ellen Pleasant: Unsung Heroine”, Crisis, Jan-Feb, 1999.

Da Breo, D. Sinclair

1971 "The West Indies Today: A Thesis on the Forces, Struggles, Frustrations and Peoples of the West Indies”. (Bridgetown: privately published, Letchworth P) 117 pages pb, frontis, 1971). Politics. Caribbean area. A political and economic study. Com, Gos.

Dagbovie, Pero Gaglo.

2003 Black Women, Carter G. Woodson, and the Association for the Study of Negro Life and History, 1915-1950. The Journal of African American History, 88:1 [Winter 2003] p.21-41 
Dookhan, Isaac

1994 A History of the Virgin Islands of the United States. 3rd ed.

Kingston, Jamaica: Canoe Press.

Dookhan, Isaac

2000

A History of the Virgin Islands of the United States. University Press of the West Indies.

Diouf, Sylviane A.

2007 Dreams of Africa in Alabama: The Slave Ship Clotilda and the Story of the Last Africans Brought to America, Oxford University Press, USA.

Diouf, Sylviane A.

2007 African Resistance, The Abolition of The Slave Trade, Schomburg Center for Research in Black Culture

http://abolition.nypl.org/print/african_resistance/

Drewry, Jennifer M.

1999 Mary Fields a Pioneer in Cascade’s Past, Footsteps Magazine, Peterborough, NH, March/April 1999.

Dwyer, Jeff

2007

Ghost Hunter's Guide to New Orleans, Pelican Publishing, 2007.

Ebony Magazine, June 1993, pp. 56, 58-60, 62, 64; September 1993, pp. 52, 54, 56, 58, 60,62 .

Edwards, Bryan

1793 History, Civil and Commercial, of the British Colonies in the West Indies, 1793.

Ellis, Patricia

1985 Women of the Caribbean, Kingston. Kingston Publishers.

Ferguson, Moira

1997 The History of Mary Prince. University of Michigan Press. Anne Arbor.

Gabriel, Deborah

2004 Jamaica's True Queen: Nanny of the Maroons, September 2, 2004

http://www.jamaicans.com/articles/primearticles/queennanny.shtml 
Geary, Patrick J.,

$2006 \quad$ Women at the Beginning: Origin Myths from the Amazons to the Virgin Mary, Princeton University Press.

Goveia, Elsa V.,

$1965 \quad$ Slave Society in the British Leeward Islands at the End of the Eighteenth Century. New Haven, CT: Yale Univ. Press.

Grant, Lennox

2005 Who remembers Gene Miles? Not NAR, Trinidad Guardian, July 24, 2005,

Trinidad Publishing Company Limited, (C2004-2005

Gray, Eliza

2009 Civil Rights: A Forgotten Contribution, NEWSWEEK, March 2, 2009.

Haiti Support Group Web Site

2010 Famous Haitians; Accessed April 20, 2010,

http://www.haitisupport.gn.apc.org/10_fam_main.html\#ptop

Hart, Richard

$1980 \quad$ Slaves Who Abolished Slavery: Blacks in Bondage, (Vol 1) Kingston, University of the West Indies

Hart, Richard

1985 Slaves Who Abolished Slavery: Blacks in Rebellion, (Vol2)

Kingston, University of the West Indies.

Hector, Leonard T.,

$1996 \quad$ Women in Antigua - A Historical Overview, December 17, 1996.

FAN THE FLAME. Web site address:

http://www.candw.ag/ jardinea/ffhtm/ff980213.htm

Hector, Leonard T.,

1998 Women \& Youths in Antigua - The Hidden Story, February 13, 1998.

FAN THE FLAME. Web site address:

http://www.candw.ag/ jardinea/ffhtm/ff980213.htm

Higman, Barry W.

1984 Slave Populations of the British Caribbean, 1807-1834. Baltimore: Johns Hopkins University Press. 
Historical Biographies, Elma Francois, (C) Paria Publishing Co. Ltd. 2000; Newsday’s Millennium Special, January 1, 2000, Pages 34-35.

History Now: American History Online, Gilder Lehrman Institute of American History, Quarterly Journal, Issue 2, December 2004

http://www.historynow.org/12_2004/lp1.html

Holdredge, Helen

1953 Mammy Pleasant: A San Francisco Scandal. New York City: G. P.

Putnam and Sons, 1953.

Horne, Earlene

2003

“Women In Politics: Elma Francois” CAFRA News, November 23, 2003.

Hooks, Bell

1981

Ain't I a Woman?. Boston: South End, 1981.

Hoose, Phillip M.

2009 Claudette Colvin, Twice Toward Justice, Farrar, Straus and Giroux (BYR)

Hudson, Lynn M.

2002 The Making of "Mammy Pleasant": A Black Entrepreneur in NineteenthCentury San Francisco, University of Illinois Press; 1st edition, 2002.

Independent, Women of the Century, Page 18, January 14, 2000.

IslandMix Forums, Jamaica's True Queen: Nanny of the Maroons, November 20, 2005.

James, Leslie R., Review of Werner Zips, Black Rebels: African-Caribbean Freedom

2000 Fighters, DePauw University, The North Star, Vol.3, no.2, Spring 2000.

Jensen, Peter

1998 From Serfdom to Fireburn and Strike: the History of Black Labor in the Danish West Indies, 1848-1916. Christiansted, St. Croix [V.I.]:

Antilles Press,

Johnson, Jason B.

2005 A Day for 'Mother of Civil Rights': Entrepreneur Sued to Desegregate Streetcars in 1860s, San Francisco Chronicle, February 10, 2005, p. B-4.

Jomini, Antoine-Henri

$1842 \quad$ Histoire critique et militaire des guerres de la Révolution. Brussels. 
Klein, Herbert S.

1986 African Slavery in Latin America and the Caribbean. Oxford University Press, (New York, 1986)

Lauring, Paulle

1960 A History of the Kingdom of Denmark. Translated by David Hohnen. Host \& Son: Copenhagen.

Leith-Ross, Sylvia

1939 African Women: A Study of the Ibo of Nigeria. London: Faber and Faber. Reprint, New York: Praeger, 1965.

Leslie, 'Disturbances' of the 1970s, Triniview.com, June 13, 2005;

http://www.triniview.com/articles/13062005.html

Luke, Learie B.

2007

Identity and Secession in the Caribbean: Tobago versus Trinidad, 18891980, Kingston: University of West Indies Press, 2007.

Lux, William R.

$1972 \quad$ Black Power in the Caribbean, Journal of Black Studies, Vol. 3, No. 2. Dec., 1972, pp. 207-225.

MacLean, Geoffrey

Gang-Gang Sarah, Strabon-Caraibes, Citizens for Conservation, Web access: July 12, 2010

http://trinidad-tobago.strabon-

caraibes.org/index.php?option=com content\&view=category\&layout=blog\&id=14\&Itemid=44

Mair, Lucille Mathurin

1975 “The Arrivals of Black Women.” Jamaica Journal, 9, 2-3 (1975a): 2-7.

Marshall, Trevor

2009 Nanny Grigg Deserves National Hero Status, The Barbados Advocate Newspaper, February 20, 2009.

Martin, Susan M.

1988 Palm Oil and Protest: An Economic History of the Ngwa Region, SouthEastern Nigeria, 1800-1980. New York: Cambridge University Press, 1988. 
Mathis, R.

2001 The Black Woman in the Public Eye: An Ethnoanthropological

Perspective, Freedom in Black History and Culture, Middletown, Arrow Point Press.

Mayo, Father James

2010 St. Michael the Archangel Catholic Church, Portland, Oregon, Gospel Reading and Homily, John 8:1-11, Sunday, March 21, 2010.

Méléance, Emide

2006 Catherine Flon and the Creation of the Haitian Flag, in Revolutionary Freedoms: A History of Survival, Strength. Coconut Creek, FL, Caribbean Studies Press, p. 91f.

Miller, Robert

1977 The Story of Stagecoach Mary Fields, Silver Burdett Press, 1995; Article in Ebony 32 (October 1977), pp.96-98

Mintz, Sidney

1996 Black Women, Economic Roles and Cultural Traditions, Caribbean Freedom: Economy and Society from Emancipation to the Present, Ed. Hilary Beckles and V. Shephered: 238-244

Momsen, Janet $\mathrm{H}$.

1996 Gender Roles in Caribbean Agricultural Labor, Caribbean Freedom: Economy and Society from emancipation to the present, Ed. Hilary Beckles and V. Shephered: 216-224

Morrissey, Marietta

1989 Slave Women in the New World: Gender Stratification in the Caribbean, University Press of Kansas, 1989.

Morton, Patricia

1991

Disfigured Images: The Historical Assault on Afro-American Women.

Praeger Publications.

Naipaul, V. S.

1970

“Power to the Caribbean people.” New York Review, September: 32-34; (1970:33). 
Nance, Teresa A., Hearing the Missing Voice, Journal of Black Studies, Vol. 26, No. 5, 1996 Special Issue: The Voices of African American Women in the Civil Rights Movement, pp. 543-559.

New York Post, 1211 Avenue of the Americas , New York, NY 10036-8790; The African American Registry, a resource on African American History, is a 501(c) (3) non-profit education organization. The African American Registry ${ }^{\circledR}$ Copyright 2005, 2006.

Noble, J., Beautiful, Also, are the Souls of My Black Sisters: A History of the Black $1978 \quad$ Woman in America. Englewood Cliffs, NJ: Prentice Hall.

Oakland Tribune, September 3, 1916.

Oriji, John N.,

2000 Igbo Women From 1929-1960. West Africa Review: 2 , 1.

Ottley, Carlton Robert

1972 Tall Tales of Trinidad and Tobago, Horsford Printerie Publishers ([Portof-Spain, Trinidad]), 1972.

Pasley, Victoria

1999 "Gender, Race, and Class in Urban Trinidad: Representations in the

Construction and Maintenance of the Gender Order, 1950-1980."

Unpublished Ph.D. Dissertation, University of Houston, May 1999.

Pipher, Mary

1995 Reviving Ophelia: Saving the Selves of Adolescent Girls, Ballantine Books; Reissue edition

Price, R.

1996 Maroon Societies: Rebel Slaves Communities in the Americas, Baltimore, The Johns Hopkins University Press.

Rediker, Marcus

2007 The Slave Ship: A Human History, Viking Publ.

Reddock, Rhoda

$1988 \quad$ Elma Francois, The NWSCA and the Workers' Struggle in the Caribbean, New Beacon Books Ltd, 1988

Reddock, Rhoda E.

$1994 \quad$ Women Labour and Politics in Trinidad and Tobago, Zed Books, London. 
Reverby, Susan

$1976 \quad H o s p i t a l$ Organizing in the 1950s: An Interview with Lillian Roberts, Signs, Vol. 1, No. 4. (Summer, 1976), pp. 1053-1063.

Richards, Peter 2009

President in Power Grab, Citizen Groups Say, Spiceislander.com, January 24th, 2009 . http://cache.zoominfo.com/CachedPage/?archive_id=0\&page_id=1527904473\&page_url=\%2f\%2fwww.spiceislander.com\%2f\%3fp\%3d923\%23more923\&page_last_updated=2\%2f3\%2f2009+4\%3a57\%3a33+PM\&firstName=Hazel\&lastN ame=Brown

San Francisco Examiner, October 13, 1895; January 11, 1904.

Shah, Raffique

2001 A Culture Of Corruption, "Jean Miles Hero of Trinidad and Tobago Against Corruption”, July 22, 2001.

http://www.trinicenter.com/Raffique/2001/Jul/222001.htm

Shephderd, Verene A.

$1999 \quad$ Women in Caribbean History: The British-Colonised Territories, Markus Wiener Publishers, Inc.

Spender, Dale 1990

Man-Made Language, Pandora Press; 2 edition, 1990.

Tallant, Robert

$1994 \quad$ Voodoo in New Orleans, Pelican Publishing, 1994.

The Butcher's Floor, Mammy" Pleasant - San Francisco Voodoo Queen (1814-1904), August 21, 2006. http://butchersfloor.blogspot.com/2006/08/mammy-pleasant-san-francisco-voodoo.html

The Montgomery Advertiser, They Changed the World: The Story of the Montgomery Bus Boycott $\quad$ http://www.montgomeryboycott.com/frontpage.html

Tidings, a newsletter of Friends of Virgin Islands National Park. Web Address: http://www.friendsvinp.org/archive/05tdsummer.pdf

Tircuit, Angela

2006 Before Rosa Parks, There was Claudette Colvin, Associated Content, August 15, 2006

http://www.associatedcontent.com/article/51163/before_rosa_parks_there_was_claudette.html?cat=38 
Toussaint Louverture's nephew. The Louverture Project;

http://thelouvertureproject.org/index.php?title=Sanite_B\%C3\%A9lair

Tremlett, Giles

2006 "Lost Document Reveals Columbus as Tyrant of the Caribbean”; The Trinidad Guardian, August 7, 2006.

Trinidad and Tobago Express, Brown: Govt Gender Policy Garbage, March 7, 2010. http://www.trinidadexpress.com/index.pl/article_news?id=161604576

Trinidad Guardian, “Millions of Dollars in Gas Deals, Alleges Miss Miles.” 22 July 1966: 1 .

Trinidad Guardian, “Model: Tam Sold 'Secrets,” 23 Jul. 1966: 1.

Wagner Labor Archives, “The Momentum Was Catching On:” Lillian Roberts Describes Organizing Hospital Workers in New York City. Courtesy of the Wagner Labor Archives; History Matters, U.S. Survey Course on the Web, http://historymatters.gmu.edu/d/6944/

Washington, Clare

2009 “Interview with Antoinette Harrell”, Kentwood, Louisiana, January 28, 2009.

Washington, Clare

2008 "Interview with Dr. Rita Pemberton, University of the West Indies, St. Augustine, Trinidad and Tobago, W.I, May, 2008.

Washington, Clare

2008 “Interview with Kafra Kambon”, Trinidad and Tobago, W.I., July 6, 2008.

Washington, Clare J.

2008 Lillian Davis Roberts, The African American National Biography, Henry Louis Gates and Evelyn Brooks Higginbotham, eds., Oxford University Press, 2008

White, J., Black Leadership in America from Booker T. Washington to Jesse Jackson $1990 \quad$ (2nd ed.). New York: Longman. 
Wikipedia Contributors

2010

"Anacaona”, Wikipedia, the Free Encyclopedia. Wikipedia, the Free Encyclopedia, 23 Jun. 2010. Web. 12 Jul. 2010.

http://en.wikipedia.org/wiki/Anacaona

Wikipedia Contributors

2009

"Igbo Women's War." Wikipedia, The Free Encyclopedia. Wikipedia, The Free Encyclopedia, 6 Nov. 2009. Web, 9 Apr. 2010.

Wikipedia Contributors

2010

"Mum Bett." Wikipedia, the Free Encyclopedia. Wikipedia, the Free Encyclopedia, 26 Mar. 2010. Web. 29 Mar. 2010.

Wikipedia contributors

2010 "Slave Rebellion.” Wikipedia, The Free Encyclopedia. Wikipedia, The

Free Encyclopedia, 28 Jun. 2010. Web. 14 Jul. 2010

Wikipedia, The Heritage Library via the Trinidad Guardian, Web access: July 12, 2010; http://en.wikipedia.org/wiki/Gang_Gang_Sarah

Wilder, Ann Elizabeth

2001

The Grenada Revolution Online, 2001-2008.

http://www.thegrenadarevolutiononline.com/sitemap.html

Woodson, Carter G.

1930 “The Negro Washerwoman, A Vanishing Figure,” Journal of Negro

History, July 1930, pp. 270, 272.

Zips, Werner

1999

Black Rebels: African Caribbean Freedom fighters in Jamaica, Kingston, Ian Randle Publishers 


\section{APPENDICES}

\section{APPENDIX A}

Table 1

\begin{tabular}{|l|l|}
\hline \multicolumn{1}{|c|}{$\begin{array}{l}\text { REVOLT, RESISTANCE \& REBELLION TIMELINE IN } \\
\text { TRINIDAD AND TOBAGO } \\
\text { Table 1 }\end{array}$} \\
\hline $\mathbf{1 6 8 5}$ & $\begin{array}{l}\text { French Code Noir, a set of harsh Laws against African dance and drumming } \\
\text { assemblies. After that those assemblies were used for the staging grounds for } \\
\text { revolt and rebellion. }\end{array}$ \\
\hline $\mathbf{1 6 9 9}$ & $\begin{array}{l}\text { December: Arena Massacre - at San Francisco de las Arenales (Arena), } \\
\text { Amerindians revolt against Spanish Governor José León de Echales and the } \\
\text { Capuchin missionaries; Echales is killed }\end{array}$ \\
\hline $\mathbf{1 7 4 5}$ & Cabildo of St. Joseph rebels against Governor. \\
\hline $\mathbf{1 7 7 0}$ & $\begin{array}{l}\text { First of a series of four rebellions, (1770, 1771, 1773 \& 1774) by the enslaved } \\
\text { population in Tobago; enslaved person called Sandy along with six others } \\
\text { attacked a military post in November of 1770. First attacking Courland Estate } \\
\text { then the rebellion spread to other estates including Mt. Irvine and Riseland and } \\
\text { continued for six weeks. }\end{array}$ \\
\hline $\mathbf{1 7 7 4}$ & $\begin{array}{l}\text { Tobago) House of Assembly and Legislative Council call for more troops into } \\
\text { Tobago to ease the economic crisis. }\end{array}$ \\
\hline $\mathbf{1 7 9 0}$ & Scarborough burnt to the ground after mutiny of French soldiers. \\
\hline $\mathbf{1 7 9 9}$ & $\begin{array}{l}\text { Both houses of the Tobago Parliament prepared a report on the amelioration of } \\
\text { African slavery in the colonies, with credit being given to Tobago. }\end{array}$ \\
\hline $\mathbf{1 8 0 1}$ & $\begin{array}{l}\text { Tobago - discovery of elaborate plans for a slave revolt, Christmas night. } \\
\text { Revisiting the Act of } 1776, \text { with respect to the Marital Laws. } 200 \text { slaves arrested. } \\
\text { Estates involved; Bacolet, Belvedere, Cove, Friendship, Friendsfield, Hope, } \\
\text { Mesopotomia }\end{array}$ \\
\hline $\mathbf{1 8 0 5}$ & $\begin{array}{l}\text { Tobago - Christmas by slaves to destroy the white inhabitants of the colony. } \\
\text { Resulting from the Act of 1801 and the infringement of rights to both slaves and } \\
\text { freed Africans. }\end{array}$ \\
\hline $\mathbf{1 8 0 6}$ & Slave trade was prohibited in the new British colonies \\
\hline $\mathbf{1 8 0 7}$ & $\begin{array}{l}\text { Abolition of British slave trade } \\
\text { pass tho- Joseph Robley’s Estate: a gang at Cove turned into a riot that tried to }\end{array}$ \\
\hline
\end{tabular}




\begin{tabular}{|l|l|}
\hline $\mathbf{1 8 1 5}$ - & $\begin{array}{l}\text { Six Companies of black American ex-slaves who fought for Britain in the War } \\
\text { of } 1812 \text { settle in six Company Villages in south central Trinidad }\end{array}$ \\
\hline $\mathbf{1 8 2 0}$ & Marital law lifted and military activity slackened in Tobago. \\
\hline $\mathbf{1 8 2 4}$ & Order in Council for the Amelioration of slavery \\
\hline $\mathbf{1 8 3 2}$ & Slave uprising on the Plein Palais Estate in Point a Pierre in Trinidad \\
\hline $\mathbf{1 8 3 4}$ & Abolition of slavery in the British Empire; beginning of Apprenticeship \\
\hline $\mathbf{1 8 3 5}$ & $\begin{array}{l}\text { In Tobago, 'Obeah' had been practiced in secret and now could no longer be } \\
\text { suppressed }\end{array}$ \\
\hline $\mathbf{1 8 3 8}-$ & Approximately 100,000 British West Indian immigrants settled in Trinidad. \\
$\mathbf{1 9 3 1}$ & Great influx, 65,000 between 1871- 1911. \\
\hline Sources: \\
1). Anthony, Michael. First in Trinidad. Port of Spain: Trinidad. Paria Publishing Company, \\
2004 \\
2). Brereton, B. Race Relations in Colonial Trinidad 1870-1900. Cambridge: England. \\
Cambridge University Press,1979. \\
3). De Verteuil, Fr. Anthony. The Years of Revolt Trinidad 1881-1888. Port of Spain: Trinidad. \\
Paria Publishing Company, 1984. \\
4). Henry, Frances. Reclaiming African Religions in Trinidad. Port of Spain: Trinidad. UWI \\
Press, 2003. \\
5). Laurence, K.O. Tobago in Wartime 1798-1815. Kingston: Jamaica. University Press, 1995 \\
6). Ome, Aiyegoro. The Story of Emancipation. Port of Spain: Trinidad. Pegasus Publishing \\
and Marketing Enterprises, 1989. \\
7). Ottley,C.R.. The Story of Tobago. Jamaica. Longman, 1973. \\
8). Rennie, Bukka. History of the Working Class in the Twentieth Century. Port of Spain: \\
Trinidad. New Beginning Movement, 1974. \\
9). Williams, Eric. The History of the People of Trinidad \& Tobago. New York: USA. A \& B \\
Publishers, 1942. \\
10). Wood, Donald. Trinidad in Transition: The Years After Slavery. New York: USA. Oxford \\
University Press, 1986 \\
11). Woodcock. Henry. Iles. A History of Tobago. Port of Spain: Trinidad. Columbus \\
Publisher.
\end{tabular}




\section{APPENDICES}

\section{APPENDIX B}

Table 2

\begin{tabular}{|c|c|c|c|c|}
\hline \multicolumn{5}{|c|}{ Other Lesser-Known Resistance Leaders } \\
\hline Personality & Location & Event & Time & Other \\
\hline Queen Kahina & North Africa & $\begin{array}{l}\text { Fought Arab incursion } \\
\text { in North Africa }\end{array}$ & & Died in 705 A.D. \\
\hline $\begin{array}{l}\text { Hatshepsut, Tiye } \\
\text { and Nefertari, } \\
\text { Nefertiti Nandi }\end{array}$ & $\begin{array}{l}\text { Queen of } \\
\text { Zululand }\end{array}$ & $\begin{array}{l}\text { overcame many } \\
\text { obstacles to raise to a } \\
\text { power in all Zululand }\end{array}$ & $1778-1826$ & Mother of Shaka Zulu \\
\hline $\begin{array}{l}\text { Empress Taytu } \\
\text { Betul }\end{array}$ & Ethiopia & $\begin{array}{l}\text { led the conservative } \\
\text { faction that resisted the } \\
\text { modernists }\end{array}$ & $1889-1913$ & $\begin{array}{l}\text { she was a key player in } \\
\text { the conflict over the } \\
\text { Treaty of Wuchale with } \\
\text { Italy }\end{array}$ \\
\hline $\begin{array}{l}\text { Mary Church } \\
\text { Terrell }\end{array}$ & $\begin{array}{l}\text { Washington, } \\
\text { DC }\end{array}$ & $\begin{array}{l}\text { had been a leader in the } \\
\text { fight to end Jim Crow } \\
\text { segregation }\end{array}$ & 1954 & $\begin{array}{l}\text { Born in 1863, during the } \\
\text { Civil War, and died in } \\
1954\end{array}$ \\
\hline Ida B.Wells & Tennessee & $\begin{array}{l}\text { went on to lead the } \\
\text { American anti-lynching } \\
\text { crusade }\end{array}$ & 1892 & $\begin{array}{l}\text { born the daughter of } \\
\text { slaves in Holly Springs, } \\
\text { Mississippi, on July 16, } \\
1862\end{array}$ \\
\hline $\begin{array}{l}\text { Queen Mother } \\
\text { Moore }\end{array}$ & Louisiana & demanded reparations & 1950s & Grandfather lynched \\
\hline Louisa Picquet & $\begin{array}{l}\text { South } \\
\text { Carolina; } \\
\text { Buffalo, NY }\end{array}$ & $\begin{array}{l}\text { Worked to free her } \\
\text { mother (in Texas) }\end{array}$ & May 1860 & $\begin{array}{l}\text { As a baby, she and her } \\
\text { mother were sold to a } \\
\text { plantation owner in } \\
\text { Georgia }\end{array}$ \\
\hline \multicolumn{5}{|c|}{ Table 2} \\
\hline
\end{tabular}


APPENDICES

APPENDIX C

Table 3

\begin{tabular}{|l|l|}
\hline \multicolumn{1}{|c|}{$\begin{array}{c}\text { REVOLTS, RESISTANCE \& REBELLIONS IN } \\
\text { THE UNITED STATES }\end{array}$} \\
\hline 1712 & $\begin{array}{l}\text { New York was the site of the first slave uprising in America; the remaining } \\
\text { rebels were burned slowly at the stake. }\end{array}$ \\
\hline 1739 & 1Stono Rebellion (South Carolina, Suppressed) \\
\hline 1741 & New York Conspiracy (New York City, Suppressed) \\
\hline 1800 & Gabriel Prosser (Virginia, Suppressed) \\
\hline 1805 & Chatham Manor (Virginia, Suppressed) \\
\hline 1811 & $\begin{array}{l}\text { One of the largest slave revolts in the United States occurred in Louisiana; and } \\
\text { involving some 300 to 500 rebels }\end{array}$ \\
\hline 1815 & George Boxley (Virginia, Suppressed) \\
\hline 1822 & Denmark Vesey (South Carolina, Suppressed) \\
\hline 1831 & Nat Turner's Rebellion (Virginia, Suppressed) \\
\hline 1841 & Creole, ship rebellion (Off the Southern U.S. coast, Victorious) \\
\hline 1859 & John Brown's Raid -- Harper's Ferry (Virginia, Suppressed) \\
\hline & \\
\hline Sources: \\
\hline $\begin{array}{l}1 \text { 1). Wikipedia contributors. "Slave rebellion." Wikipedia, The Free Encyclopedia. } \\
\text { Wikipedia, The Free Encyclopedia, 28 Jun. 2010. Web. 14 Jul. 2010 }\end{array}$ \\
\end{tabular}




\section{VITA AUCTORIS}

Clare J. Washington, a transplant from Southern California, holds a B.S. with high honors and distinction in Black Studies and English/Professional Writing from Portland State University (2007) and a M.S. (Summa Cum Laude) in Interdisciplinary Studies from Portland State University (2010). Her scholarly research and teaching interests include women and resistance in the African Diaspora, exploring the roles of the lesser-known women in resistance movements both in the Caribbean and the USA, during and after the period of enslavement; African American cowgirls of the Old West; and black women sharecroppers in the southern U.S.

She is currently an adjunct instructor in the Black Studies Department at Portland State University.

She is a Ronald E. McNair Scholar (2006) and a J. William Fulbright Fellow (2008). She spent one academic year on a Fulbright grant in Trinidad and Tobago at the University of the West Indies, St. Augustine campus. During her grant period, she traveled to the Dominican Republic (Santo Domingo), Puerto Rico (San Juan) and Trinidad and Tobago studying the lives of some of the more obscure women resistance leaders in those areas.

Her research currently focuses on a comparative study of African American women of the Black Power Movement in the Caribbean region in general and Trinidad and Tobago, West Indies, in particular, and women in selected cities in the USA; women and twentieth-century slavery, women sharecroppers and peonage in the USA in general, and the Mississippi Delta, in particular; and the images of African American women in postcards, paintings, cartoons, and other media. 